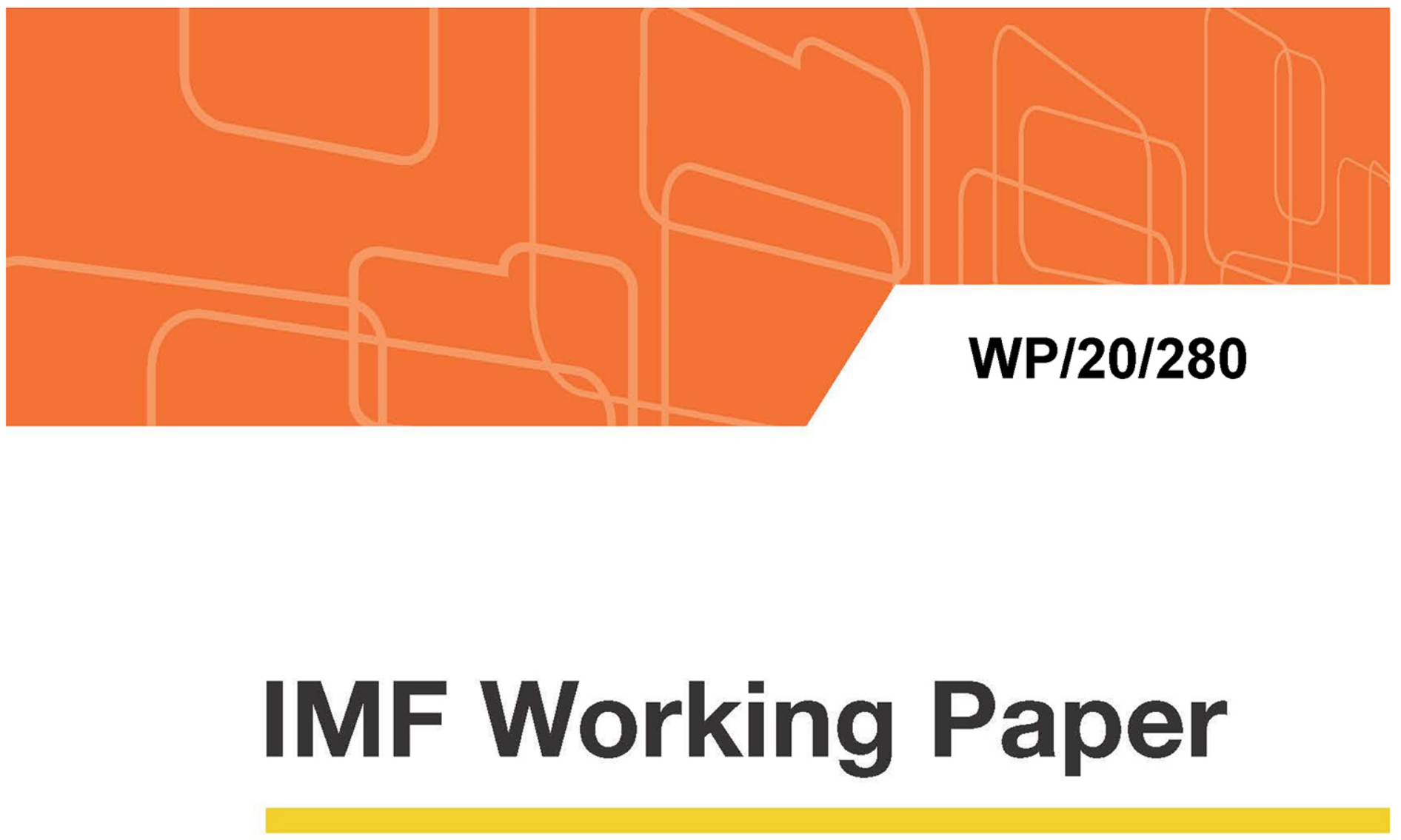

\title{
Terms-of-Trade Shocks are Not all Alike
}

by Federico Di Pace, Luciana Juvenal, and Ivan Petrella

IMF Working Papers describe research in progress by the author(s) and are published to elicit comments and to encourage debate. The views expressed in IMF Working Papers are those of the author(s) and do not necessarily represent the views of the IMF, its Executive Board, or IMF management. 


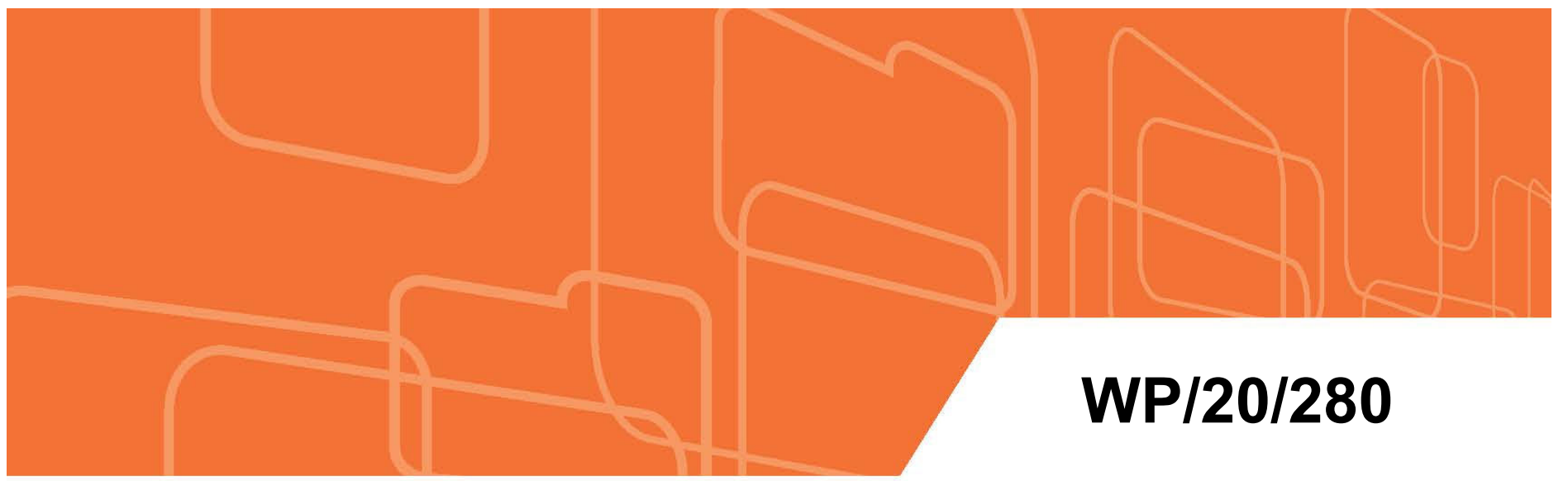

\section{IMF Working Paper}

\section{Terms-of-Trade Shocks are Not all Alike}

by Federico Di Pace, Luciana Juvenal, and Ivan Petrella

IMF Working Papers describe research in progress by the author(s) and are published to elicit comments and to encourage debate. The views expressed in IMF Working Papers are those of the author(s) and do not necessarily represent the views of the IMF, its Executive Board, or IMF management. 


\title{
IMF Working Paper
}

Research Department

\author{
Terms-of-Trade Shocks are Not all Alike* \\ Prepared by Federico Di Pace, Luciana Juvenal, and Ivan Petrella \\ Authorized for distribution by Daniel Leigh
}

December 2020

\begin{abstract}
IMF Working Papers describe research in progress by the author(s) and are published to elicit comments and to encourage debate. The views expressed in IMF Working Papers are those of the author(s) and do not necessarily represent the views of the IMF, its Executive Board, or IMF management.
\end{abstract}

\begin{abstract}
When analyzing terms-of-trade shocks, it is implicitly assumed that the economy responds symmetrically to changes in export and import prices. Using a sample of developing countries our paper shows that this is not the case. We construct export and import price indices using commodity and manufacturing price data matched with trade shares and separately identify export price, import price, and global economic activity shocks using sign and narrative restrictions. Taken together, export and import price shocks account for around 40 percent of output fluctuations but export price shocks are, on average, twice as important as import price shocks for domestic business cycles.

JEL Classification Numbers: F41, F44

Keywords: Terms of Trade, Commodity Prices, Business Cycles, World Shocks

Author's E-Mail Address: federico.dipace@bankofengland.co.uk; ljuvenal@,imf.org (corresponding author); ivan.petrella $(a)$,wbs.ac.uk.

*We are grateful to Charles Engel, Chris Papageorgiou, Adrian Peralta Alva, Pau Rabanal, Emiliano Santoro, Stephanie Schmitt-Grohé, Martín Uribe and participants at the International Monetary Fund, the Bank of England, the Money Macro and Finance Conference 2019, the Universitá della Calabria, the Society for Nonlinear Dynamics and Econometrics Conference 2020, and the CEBRA Workshop for Commodities and Macroeconomics 2020 for helpful comments.
\end{abstract}




\section{Introduction}

Developing countries are vulnerable to fluctuations in the terms of trade. Large swings occur very often and these are thought to generate abrupt changes in a country's trade balance, current account and output (see, for example, Mauro and Becker, 2006). A deterioration in the terms of trade can lead to difficulties in financing current account deficits and a large external debt. While terms-of-trade shocks are typically viewed as a major source of business cycle fluctuations in emerging and low-income countries, the literature has not provided a clear guidance on quantifying how important they are for driving a country's main macroeconomic variables. From a theoretical standpoint, the predictions of business cycle models conclude that between 30 and 50 percent of the variance of output is driven by terms-of-trade shocks (Mendoza, 1995 and Kose, 2002). However, recent empirical evidence presented in SchmittGrohé and Uribe (2018) suggests that terms-of-trade shocks explain around 10 percent of the variance of output. This has given rise to the "terms of trade disconnect puzzle:" terms-oftrade shocks appear less important in the data than in theory.

Our main contribution is to show that the "terms of trade disconnect puzzle" is explained by the fact that terms-of-trade shocks are not all alike. The terms of trade are defined as the ratio between export and import prices. As such, a terms-of-trade shock may result from a shift in export prices, import prices, or not perfectly offsetting movements in both. When analyzing terms-of-trade shocks, it is implicitly assumed that the economy responds symmetrically to an increase in export prices and a decline in import prices. We show that this is not the case and document that the effects of a positive export price shock do not mirror the effects of a negative import price shock. This could happen for a number of reasons. For example, if the exportable and importable sectors have different weights in the economy, or due to the shocks having different channels of transmissions. Drechsel and Tenreyro (2018), for instance, highlight the presence of a "borrowing cost channel" associated to shifts in the price of exports. Overall, this implies that the terms-of-trade shocks which are typically analyzed in the literature fail to capture the individual role of export and import prices in transmitting disturbances to the economy.

Our results suggest that while export price shocks have larger and more persistent effects on the economy, the impact of import price shocks is more muted. The fact that the commodity export share is much higher than the commodity import share is key to understand the heterogeneous results. In addition, global economic activity shocks, which reflect unexpected changes in global output, are a common shifter of commodity export and import prices. When global economic activity goes up, there is an increase in demand for all commodities which induces a simultaneous rise in export and import prices but could reflect a small or no change in the terms of trade. ${ }^{1}$ However, since the economy responds asymmetrically to movements in export and import prices, global economic activity shocks, while largely not visible in the terms of trade metric, play an important role for developing countries' business cycles. The documented high correlation between commodity export and import prices is to a large extent explained by the fact that they are driven by the global economic activity shock.

In order to investigate the transmission of export and import price shocks separately, we construct a comprehensive time series of country-specific export and import price indices for a sample of emerging and developing economies. ${ }^{2}$ Specifically, we calculate these indices using individual commodity and manufacturing prices combined with time-varying sectoral export and import shares. This extends earlier work that has followed a similar approach but only focused on the construction of terms of trade measures based on prices of raw commodities

\footnotetext{
${ }^{1}$ Juvenal and Petrella (2015) show that global demand shocks are the main drivers of the co-movement between commodity prices. See also Alquist, Bhattarai, and Coibion (2020); and Delle Chiaie, Ferrara, and Giannone (2017).

${ }^{2}$ This dataset will be updated on regular time intervals and available from our websites.
} 
Figure 1: Comparison Forecast Error Variance Decomposition

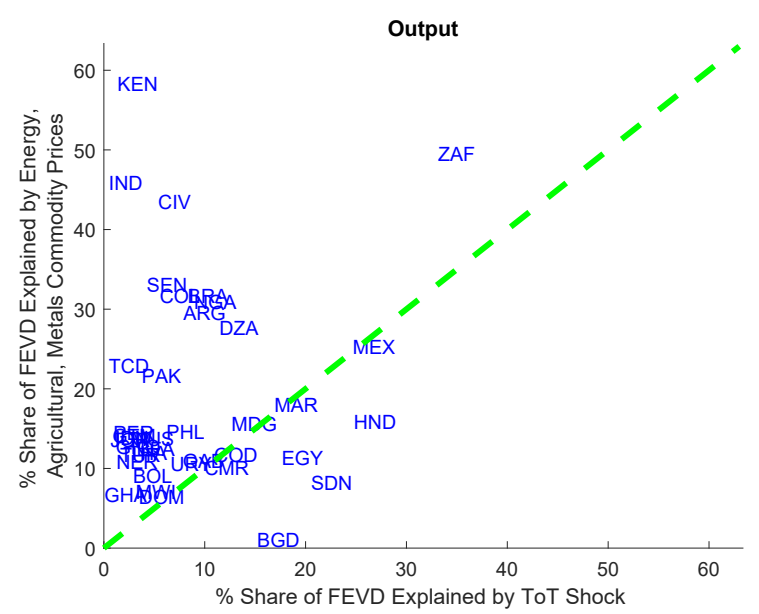

(a) $T o T$ Shocks and World Shocks

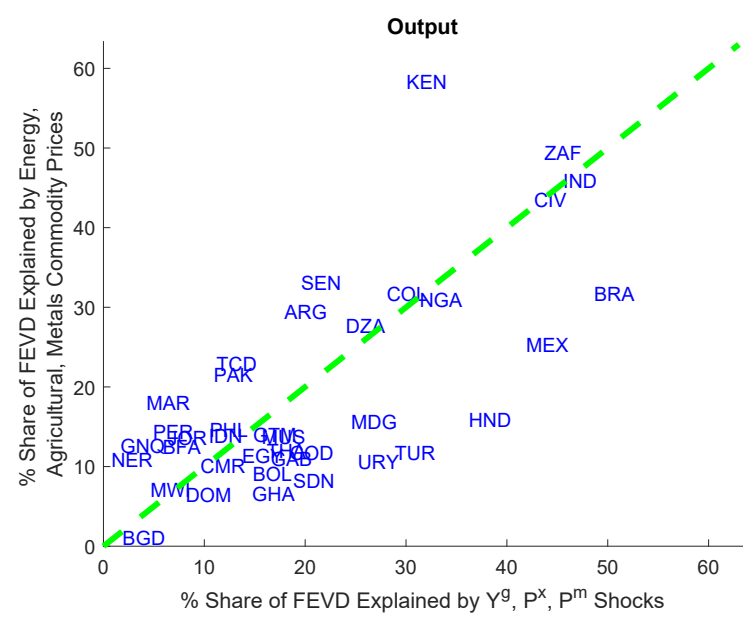

(b) World Shocks vs. $P^{x}, P^{m}$ and $Y^{g}$ Shocks

Notes: The first panel of this Figure compares the one-year ahead forecast error variance decomposition of output, for each country, obtained in Schmitt-Grohé and Uribe (2018) (x-axis) vis-à-vis Fernández et al. (2017) ( $y$-axis). The second panel shows a comparison of the forecast error variance decomposition of output, for each country, obtained in our model ( $x$-axis) comprising export price $\left(P^{x}\right)$, import price $\left(P^{m}\right)$ and global economic activity shocks $\left(Y^{g}\right)$ vis-à-vis Fernández et al. (2017) (y-axis).

(see, Deaton and Miller, 1996; and Cashin, Céspedes, and Sahay, 2004). With regard to the methodology, we follow the recommendation of the IMF Export and Import Price Manual. By and large, our terms of trade measure offers an improvement with respect to the official one based on unit values derived from countries' customs data. As documented in Kravis and Lipsey (1971) and Silver (2009), the latter measure is likely to contain biases originated in, for example, changes in the mix of heterogeneous products or incorrect recording of quantities.

One conjecture in Schmitt-Grohé and Uribe (2018) is that the "disconnect" could be partly driven by the fact that terms-of-trade shocks may fail to capture the transmission mechanism of world shocks. In fact, Fernández, Schmitt-Grohé and Uribe (2017) argue that world shocks propagate to the domestic business cycle through commodity prices and show that fluctuations in the latter explain a sizable proportion of domestic business cycles. To illustrate this result, the scatter plot presented in Panel (a) of Figure 1 compares, for each country, the one-year ahead forecast error variance decomposition of output driven by terms-of-trade shocks (as in Schmitt-Grohé and Uribe, 2018) and driven by world shocks, captured by three commodity prices (as in Fernández et al., 2017). ${ }^{3}$ Note that most observations are concentrated above the 45 degree line. This indicates that world shocks explain a higher share of output fluctuations than terms-of-trade shocks.

Our paper proposes an explanation for why the recent empirical evidence is at odds with the predictions of theoretical models. In doing so, we bridge the gap between the literature on the "terms of trade disconnect puzzle" and the one suggesting that shocks to world commodity prices explain a large proportion of aggregate fluctuations. In particular, we highlight that a departure from a single commodity price paradigm to allow for a distinction between export and import price disturbances is important for the study of the effects of terms-of-trade shocks. The scatter plot in Panel (b) of Figure 1 illustrates that the combination of export

\footnotetext{
${ }^{3}$ We calculate the variance decomposition using our own dataset and the methodology explained in Section 3. The results are in line with those of the papers cited. The three commodity prices are: energy, agriculture and metals.
} 
price, import price and global economic activity shocks explains a share of output variance consistent with the proportion attributed to the three commodity price indices. Therefore, the three shocks that we identify are able to capture the extent to which external shocks affect economic fluctuations in developing countries and at the same time allow us to shed light on the different (or differing) channels of transmission of these shocks. Our results bring the empirical results closer to the predictions of theoretical models, therefore reinforcing the focus of policy makers on terms of trade movements. Overall, the finding that terms-of-trade shocks are empirically important for business cycle fluctuations and the fact that the implicit assumption of symmetric responses of the economy to an export price and import price shock, common in theoretical models with terms of trade, is rejected by the data, invites the use of a new theoretical framework to study imports and exports price shocks separately.

We identify export price, import price and global economic activity shocks imposing economically meaningful sign restrictions on the impulse responses of a subset of variables (see Canova and De Nicoló, 2002; and Uhlig, 2005) complemented with narrative based restrictions. The narrative approach (Antolín-Díaz and Rubio-Ramírez, 2018) allows us to narrow the set of the identified model so that it is consistent with a series of pre-specified important events. Narrative restrictions were constructed examining historical documents and newspaper articles to identify episodes of significant commodity price changes that were unrelated to important macroeconomic developments such as natural disasters, weather related shocks or major geopolitical events. From this analysis we identify a total of 23 price episodes that we use to derive narrative restrictions for export and import price shocks. In particular, we match those events to export price and import price shocks, for each country, by assessing the export and import shares of each commodity for every episode. ${ }^{4}$

We compute the variance decomposition to assess the importance of each shock in driving business cycle fluctuations. Our estimates indicate that, taken together, export price and import price shocks explain from 20 to 40 percent of output on impact and at a 10-year horizon, respectively. Moreover, we find that global economic activity shocks explain up to 32 percent of the variation in export prices and 41 percent of the variation in import prices while they account for only one-fourth of the variation in the terms of trade. By moving export and import prices in the same direction a large fraction of the impact of global economic activity cancels out in the terms of trade metric. However, it is relevant to explain business cycles fluctuations through the asymmetric effects of export and import prices.

Given that aggregate results mask a great deal of heterogeneity across countries, we inspect the main drivers behind the different results. For export price shocks, a key characteristic to understand the heterogeneous effects on macroeconomic variables is the extent to which the export share is dominated by commodities. Following an export price shock, the effects on the real economy are more substantial for countries with a larger commodity export share. In addition, output of richer countries tends to be more responsive to export price shocks. The effects on the terms of trade after an export price shock are higher the larger the commodity export share and in countries which exhibit a higher concentration of their commodity export base. Interestingly, countries that have a higher commodity export share exhibit, on average, a larger response of export prices and the terms of trade in response to a global economic activity shock. The response of output following an import price shock is more homogeneous across countries, with richer economies displaying a smaller response of output. ${ }^{5}$

This paper contributes to the literature that analyzes the role of terms-of-trade shocks in explaining business cycle fluctuations in emerging and low-income countries. From a the-

\footnotetext{
${ }^{4}$ For example, we identify a positive coffee price shock in 1986 originated in droughts in Brazil. This episode would serve as a positive export price shock for coffee exporting countries such as Guatemala.

${ }^{5}$ The homogeneous response of output following an import price shock is confirmed when we analyze the impulse responses by splitting the countries by commodity export and import groups.
} 
oretical perspective, most papers find that terms-of-trade shocks are a significant driver of output fluctuations (Mendoza, 1995 and Kose, 2002). From an empirical standpoint, the role of terms-of-trade shocks is less important in the data than in theory because terms-of-trade shocks fail to capture the role of individual prices in transmitting world shocks (Fernández et al., 2017 an Schmitt-Grohé and Uribe, 2018). To the best of our knowledge, our paper is the first to exploit the individual role of country-specific export and import prices in transmitting shocks to business cycles. Our paper is also related to the literature that studies the relationship between terms of trade of developing countries and international prices. Bidarkota and Crucini (2000) construct a proxy of the terms of trade using world commodity prices and trade shares and conclude that a country's terms of trade variation is explained by the price volatility of the commodities in which a country specializes. Cashin et al. (2004) analyze the role of commodity price movements in explaining real exchange rate fluctuations, and find that they do for about one-third of their sample. In a related study, Ayres, Hevia and Nicolini (2020) highlight that fluctuations in commodity prices account for a large fraction of the real exchange rate volatility.

Our study offers some contrasts and similarities with respect to the existing literature. First, from a methodological point of view, our measure of export prices, import prices, and terms of trade extends beyond primary commodities to include also manufacturing. This is important, in particular for import prices. We show that not accounting for the share of manufacturing overstates the volatility of export and import prices and yields less volatile terms of trade. Second, our results suggest that differences in the commodity intensity play an important role in explaining the heterogeneous impact of export and import price shocks. In line with the literature, we find that shocks to export prices (which are largely dominated by raw commodities) explain a large fraction of the variation in the terms of trade and the real exchange rate.

The paper is organized as follows. Section 2 presents the data, details the methodology to calculate the country-specific export and import prices indices and includes a rich set of descriptive statistics. Section 3 shows the empirical methodology and identification strategy. Section 4 discusses the baseline results. The extensions are presented in Section 5 and Section 6 concludes. Appendix A describes the macroeconomic and commodity data, while Appendix $\mathrm{B}$ attends to the construction of narrative series of exogenous price shocks. The empirical evidence on global economic activity shocks is in Appendix C. Finally, Appendix D presents the cross-country and group heterogeneity results.

\section{Data and Descriptive Statistics}

Our data set combines information from commodity prices, U.S. producer price indices (PPI), country-specific sectoral export and import shares, and macroeconomic indicators.

We focus on emerging and low-income countries as in Schmitt-Grohé and Uribe (2018). The sample is annual and covers the period 1980-2016 for 38 countries. To be included in the sample, a country needs to have at least 30 consecutive annual observations and to belong to the group of poor and emerging countries. This group is defined as all countries with an average GDP per capita at PPP U.S. dollars of 2005 over the period 1980-2016 below 25,000 dollars according to the World Bank's World Development Indicators (WDI) database. The countries that satisfy these criteria are: Algeria, Argentina, Bangladesh, Bolivia, Brazil, Burkina Faso, Cameroon, Chad, Colombia, Congo, Cote d'Ivore, Dominican Republic, Egypt, Equatorial Guinea, Gabon, Ghana, Guatemala, Honduras, India, Indonesia, Jordan, Kenya, Madagascar, Malawi, Mauritius, Mexico, Morocco, Niger, Nigeria, Pakistan, Peru, Philippines, Senegal, South Africa, Sudan, Thailand, Turkey and Uruguay. The data coverage for each country is listed in Table A.1 of Appendix A. 
In what follows we summarize the macroeconomic data used in our analysis, explain the construction of the export and import price indices, and present some descriptive statistics.

\subsection{Macroeconomic Data}

The country-specific macroeconomic variables are real GDP per capita $(Y)$, real consumption expenditure per capita $(C)$, real gross investment per capita $(I)$, the trade balance as a percentage of GDP $(T B)$, and the real exchange rate $(R E R)$. Our empirical measure of the real exchange rate is the bilateral U.S. dollar real exchange rate defined as $R E R_{t}=\frac{E_{t} P_{t}^{U S}}{P_{t}}$, where $E_{t}$ is the official nominal exchange rate, $P_{t}^{U S}$ denotes the U.S. CPI, and $P_{t}$ is the domestic country consumer price index. Since the real exchange rate is defined as the price of foreign goods in terms of domestic goods, a decrease in RER implies a real appreciation. These variables are obtained from the WDI database with the exception of the CPI from Argentina which is sourced from Cavallo and Bertolotti (2016). We measure real world GDP using an aggregate sourced from Haver Analytics calculated based on data for 63 countries, expressed at 2010 prices and exchange rates. A full description of the macro data is detailed in Appendix A.1.

\subsection{Export and Import Price Indices}

We construct country-specific export and import price indices denominated in U.S. dollars $\left(P^{x}\right.$ and $\left.P^{m}\right)$ using sectoral export and import shares, commodity prices, and U.S. PPI data as a proxy for manufacturing prices.

The weights for the calculation of the price indices are given by the products' export and import shares. In order to calculate these shares, for each country, we obtain a time series of highly disaggregated product export and import values sourced from the MIT Observatory of Economic Complexity. ${ }^{6}$ The product data are disaggregated at the 4-digit level and classified according to the Standard International Trade Classification, Revision 2 (SITC Rev. 2). Our sample consists of 988 categories but since we only have price information of 62 categories, the trade shares are reclassified so that we can match the weights with the price data.

For 46 out of the 62 sectors we obtain commodity prices from the World Bank's Commodity Price Data (details in Appendix A.2). For 16 manufacturing categories such as transport equipment, machinery and equipment, and textile products and apparel we proxy world prices using sectoral U.S. PPI data sourced from the Federal Reserve Bank of St. Louis FRED. Table A.2 in Appendix A includes the list of the manufacturing industries used and the corresponding North American Industry Classification System (NAICS) code. In order to match the sectoral manufacturing price data with the trade shares, NAICS codes were reclassified to match with the SITC classification.

Using this information, for each country, we compute $P^{x}$ and $P^{m}$ following the indications of the IMF Export and Import Prices Manual. ${ }^{7}$ In particular, the manual explains that it is possible to calculate a chain index for import and export prices from goods specific prices as follows:

$$
P^{0: t}=P^{0: t-1} \sum_{j=1}^{\text {No.Goods }} w_{j, t-1} P_{j}^{t-1: t},
$$

where $P^{0: t}$ is the aggregate price index at time $t$ with base price at 0 (i.e. $P^{0: 0}=1$ ); $j$ denotes the good, which comprises 46 commodities and 16 manufacturing industries; $w_{j, t-1}$ is

\footnotetext{
${ }^{6}$ The data can be accessed at https://atlas.media.mit.edu/en/.

${ }^{7}$ https://www.imf .org/en/Publications/Manuals-Guides/Issues/2016/12/31/Export-and-ImportPrice-Index-Manual-Theory-and-Practice-19587.
} 
the weight of good $j$ at time $t-1$, defined as the export or import share of that good in a country's total exports or imports; and $P_{j}^{t-1: t}$ is good $j$ price index at time $t$ with base price at $t-1$. Note that since $P_{j}^{t-1: t}=P_{j}^{0: t} / P_{j}^{0: t-1}$, it is possible to use a panel of annual good prices $\left(P_{j, t}\right)$ and calculate the aggregate price index as:

$$
P^{0: t}=\prod_{\tau=1}^{t}\left[\sum_{j=1}^{\text {No.Goods }}\left(w_{j, \tau-1} \frac{P_{j, \tau}}{P_{j, \tau-1}}\right)\right] .
$$

This index allows us to use time varying weights, therefore accounting for changes in a country's composition of exports and imports across time. As we will show in Section 2.3, these changes can be quite significant for some countries.

In our empirical analysis we deflate the export and import price indices by the U.S. consumer price index (CPI), and therefore consider real dollar export and import prices (as in Cashin et al., 2004). The terms of trade of a given country are defined as the relative price of its exports in terms of its imports and can be calculated as: $T o T_{t}=\frac{P_{t}^{x}}{P_{t}^{m}}$.

\subsection{Time Variation in Trade Shares}

The left panel of Table 1 reports the values of the commodity import and export shares by country for the period 1980-2016 while the right panel describes three commodities which represent the largest proportion of imports and exports during the same period. Tables A.4A.6 in Appendix A show the same information for the subperiods 1980-1990, 1990-2000, and 2000-2016, respectively. ${ }^{8}$

From Table 1 it is clear that developing countries depend heavily on commodity exports and that exports are very concentrated on a few commodities while imports are much more disperse. As an illustration, in approximately half of the countries, exports of three main commodities account for more than 50 percent of a country's total exports. In addition, for 70 percent of the countries, total commodity exports represent more than half of their export earnings. By contrast, import shares implied by the sum of the three main commodity imports account for less than 40 percent of total imports. This is not surprising given that developing countries' economies are less diversified and therefore tend to import a wide range of products.

We observe that countries specialize in exports of different groups of commodities. However, many of them depend on exports of crude oil and food. ${ }^{9}$ In fact, looking at the figures for the entire period, crude oil is the main export for 10 countries while food is the main export for 7 countries. There are, however, some striking differences across countries. While total commodity exports represent 17 percent in Bangladesh, they account for 92 percent of total exports for Algeria for the period between 1980 and 2016. Given that many countries also depend on crude oil and food imports, the concentration of imports and exports suggests that the terms of trade variation in developing countries may be driven by price fluctuations in key commodities. In addition, the fact that exports of a few commodities represent such a large share of total exports while the importance of commodity imports is much smaller, presumably indicates that price shocks affecting exports may have different effects on the economy than price shocks affecting imports.

There is a group of countries for which we observe that the main commodities exported and imported shifted significantly across the different periods. For example, Figure 2 shows that

\footnotetext{
${ }^{8}$ The breakdown of trade shares by subperiods allows us to gauge how countries' import and export structures have changed during the time span we analyze.

${ }^{9}$ Throughout out paper we use cereals as a proxy for food. Evidence suggests that cereals are the most important source of food consumption. This is documented by the FAO and further information can be found here: http://www.fao.org/docrep/006/Y4683E/y4683e06.htm.
} 
Table 1: Commodity Imports and Exports (1980-2016)

\begin{tabular}{|c|c|c|c|c|c|c|c|c|}
\hline \multirow[b]{2}{*}{ Algeria } & \multirow{2}{*}{$\begin{array}{c}\text { Comm. Imp. \% } \\
31.0\end{array}$} & \multirow{2}{*}{$\begin{array}{c}\text { Comm. Exp. \% } \\
91.9\end{array}$} & \multicolumn{3}{|c|}{ Main Imports } & \multicolumn{3}{|c|}{ Main Exports } \\
\hline & & & Food & Wheat & Met. \& Min. & Crude oil & Natural gas & Fertilizers \\
\hline Argentina & 19.1 & 71.1 & Natural gas & Met. \& Min. & Crude oil & Food & Soybean meal & Crude oil \\
\hline Bangladesh & 36.9 & 17.3 & Crude oil & Wheat & Cotton & Food & Other R. M. & Tea \\
\hline Bolivia & 20.9 & 92.8 & Met. \& Min. & Crude oil & Wheat & Natural gas & Tin & Gold \\
\hline Brazil & 34.4 & 55.3 & Crude oil & Fertilizers & Food & Iron ore & Coffee & Crude oil \\
\hline Burkina Faso & 29.1 & 91.7 & Food & Crude oil & Met. \& Min. & Cotton & Gold & Oils \& Meals \\
\hline Cameroon & 31.6 & 94.5 & Crude oil & Food & Met. \& Min. & Crude oil & Timber & Cocoa \\
\hline Chad & 21.3 & 95.0 & Food & Wheat & Met. \& Min. & Cotton & Crude oil & Other R. M. \\
\hline Colombia & 20.8 & 74.1 & Crude oil & Food & Met. \& Min. & Crude oil & Coffee & Coal \\
\hline Congo, Dem. Rep. & 29.1 & 66.7 & Food & Crude oil & Met. \& Min. & Copper & Met. \& Min. & Crude oil \\
\hline Cote d'Ivoire & 40.0 & 89.6 & Crude oil & Food & Rice & Cocoa & Coffee & Timber \\
\hline Dominican Republic & 29.3 & 37.0 & Crude oil & Food & Met. \& Min. & Sugar & Tobacco & Gold \\
\hline Egypt, Arab Rep. & 39.2 & 68.5 & Wheat & Food & Crude oil & Crude oil & Food & Cotton \\
\hline Equatorial Guinea & 31.1 & 95.2 & Met. \& Min. & Beverages & Food & Crude oil & Timber & Cocoa \\
\hline Gabon & 23.1 & 95.6 & Met. \& Min. & Food & Crude oil & Crude oil & Timber & Met. \& Min. \\
\hline Ghana & 28.2 & 88.4 & Crude oil & Food & Met. \& Min. & Cocoa & Aluminum & Timber \\
\hline Guatemala & 30.0 & 63.3 & Crude oil & Food & Met. \& Min. & Coffee & Food & Sugar \\
\hline Honduras & 28.6 & 59.5 & Crude oil & Food & Met. \& Min. & Banana & Coffee & Food \\
\hline India & 41.5 & 33.7 & Crude oil & Gold & Fertilizers & Food & Crude oil & Met. \& Min. \\
\hline Indonesia & 34.5 & 64.1 & Crude oil & Met. \& Min. & Other Raw Mat. & Crude oil & Natural gas & Food \\
\hline Jordan & 36.6 & 59.2 & Crude oil & Food & Met. \& Min. & Fertilizers & Food & Met. \& Min. \\
\hline Kenya & 30.4 & 78.3 & Crude oil & Met. \& Min. & Palm oil & Tea & Coffee & Food \\
\hline Madagascar & 25.9 & 69.2 & Rice & Met. \& Min. & Food & Food & Coffee & Met. \& Min. \\
\hline Malawi & 22.5 & 90.7 & Fertilizers & Met. \& Min. & Food & Tobacco & Tea & Sugar \\
\hline Mauritius & 28.7 & 41.6 & Food & Crude oil & Met. \& Min. & Sugar & Food & Precious \\
\hline Mexico & 20.1 & 35.4 & Met. \& Min. & Crude oil & Food & Crude oil & Food & Met. \& Min. \\
\hline Morocco & 36.9 & 49.5 & Crude oil & Wheat & Fertilizers & Food & Fertilizers & Orange \\
\hline Niger & 29.0 & 29.3 & Food & Met. \& Min. & Tobacco & Crude oil & Met. \& Min. & Food \\
\hline Nigeria & 24.5 & 97.3 & Food & Met. \& Min. & Crude oil & Crude oil & Natural gas & Cocoa \\
\hline Pakistan & 43.4 & 25.8 & Crude oil & Palm oil & Fertilizers & Rice & Cotton & Food \\
\hline Peru & 30.6 & 83.5 & Crude oil & Wheat & Food & Copper & Zinc & Crude oil \\
\hline Philippines & 28.6 & 29.2 & Crude oil & Food & Wheat & Food & Coconut oil & Copper \\
\hline Senegal & 42.0 & 78.7 & Crude oil & Food & Rice & Food & Oils \& Meals & Fertilizers \\
\hline South Africa & 20.4 & 59.5 & Crude oil & Met. \& Min. & Food & Gold & Platinum & Coal \\
\hline Sudan & 27.0 & 96.9 & Wheat & Food & Met. \& Min. & Crude oil & Cotton & Other R. M. \\
\hline Thailand & 30.5 & 38.9 & Crude oil & Met. \& Min. & Food & Food & Rice & Rubber \\
\hline Turkey & 31.9 & 34.2 & Crude oil & Iron ore & Other R. M. & Food & Met. \& Min. & Crude oil \\
\hline Uruguay & 31.7 & 60.5 & Crude oil & Food & Fertilizers & Beef & Food & Rice \\
\hline Median & 29.1 & 66.7 & & & & & & \\
\hline
\end{tabular}

up to 1987 crude oil was the main commodity export for Peru, representing over 20 percent of total exports, but afterward copper became the main export with an export share of about 24 percent. Moreover, in the 1990s Peru became a net importer of crude oil, turning into the commodity with the largest import share. These changes in the values of the trade shares have important implications for computing terms of trade. Following with the example of Peru, it is clear that in the early part of the sample the price of oil would be positively correlated with $P^{x}$ and $T o T$. In the second part of the sample it would instead be negatively correlated with $T o T$ because of its positive correlation with $P^{m}$. It is common in the literature to construct terms of trade proxies using fixed trade shares. What would happen if we measured terms of trade using a fixed trade share? Using fixed trade shares would severely bias the results against finding an important role for the terms of trade in explaining output fluctuations whenever a country trade specialization changes substantially over time so that it shifts from being a net importer to a net exporter of a given commodity (or the other way around). In the example of Peru, if we had used fixed trade shares anchored in the values of the early 1990s, the terms of trade would be negatively correlated with the "true" terms of trade in the second half of the sample. Given that a terms of trade improvement is associated with an increase in output, the terms of trade measure with fixed shares would result in a positive correlation between terms of trade and output in the early part of the sample and an erroneous negative correlation in the second part, bringing the correlation for the entire sample close to zero.

There is another group of countries for which the fraction of total exports accounted for by the single most important commodity is very large. Even within this group, export shares 

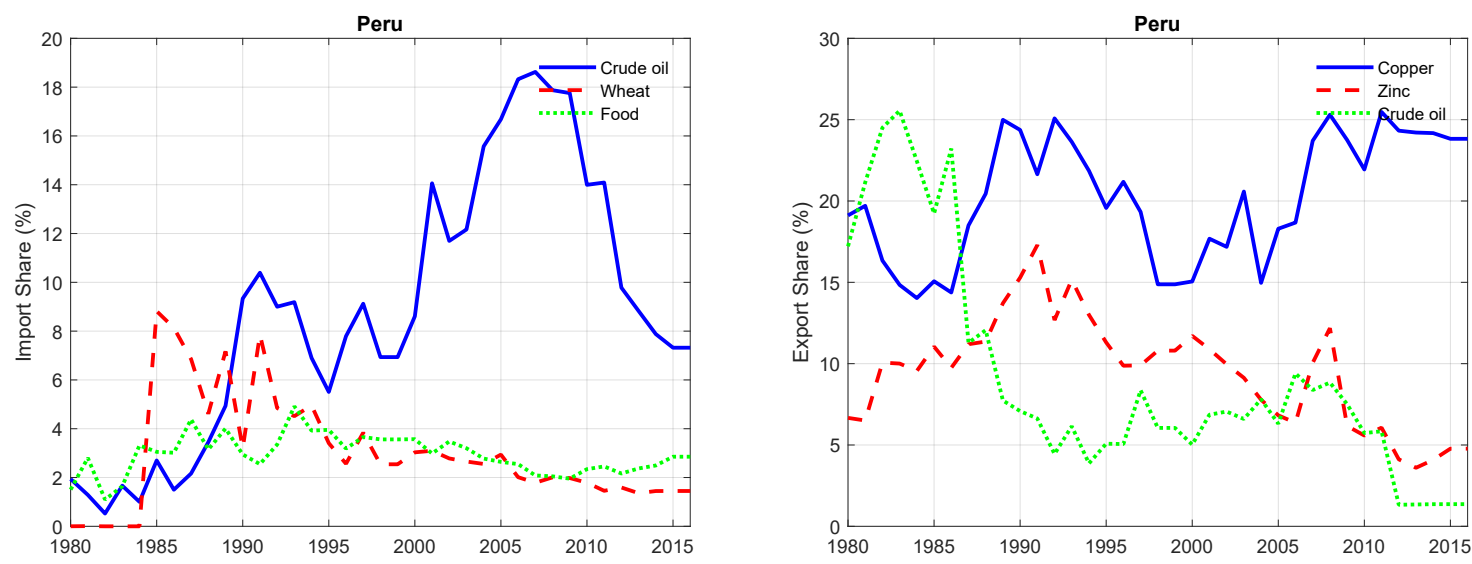

Notes: This Figure shows the evolution of import and export shares of the three main commodities imported and exported by Peru for the period 1980-2016.

exhibit some variation in the different subperiods. For example, crude oil has been persistently the most important commodity export for Algeria, but it represented 77 percent of total exports in 1980-1990, 60 percent in 1990-2000, and 59 percent in 2000-2016. Similarly, cotton is consistently the main export for Burkina Faso, with the export shares ranging from 35 to 56 percent in the subperiods analyzed.

These examples highlight the importance of using time-varying trade shares given that the shifts in trade specialization over time are present for the majority of countries. The change in the pattern of export specialization is related to the findings of Daruich, Easterly and Reshef (2019) who document that these patterns are not persistent over time. Interestingly, we find a similar result not only for export but also for import specialization.

\subsection{Alternative Measures of Terms of Trade}

The official measure of the terms of trade sourced from the WDI (denoted as $T o T^{\circ}$ ) is calculated as a ratio of the export unit value index to the import unit value index. Unit values are derived from countries' customs data. As it has been pointed out in earlier literature, these indices are likely to contain biases stemming from changes in the mix of heterogeneous products recorded in customs documents or poor quality of recorded data on quantities (see Kravis and Lipsey, 1971; Silver, 2009). In addition, those biases are likely to be different for each of the countries considered.

The main advantage of the proxies of export and import prices, and hence terms of trade, that we construct is that they are entirely based on observable (world) prices and linked to each of the countries based on their trade exposure. As shown in the first column of Table 2, (the quadratically detrended log of) our measure of the terms of trade is positively correlated with official one sourced from WDI: for most of the countries (23 out of 38 ) the correlation in the detrended data is higher than 0.5. ${ }^{10}$

The commodity terms of trade (hereafter $T o T^{c}$ ) is another popular measure used in the

\footnotetext{
${ }^{10}$ Given that we are linking 988 sectors into 62 categories for which we have commodity and manufacturing price data, the correlation is quite remarkable. Also note that the correlations are computed on the quadratically detrended logarithm of the data. Actual series present distinct trends that are also well captured by our measure, and the difference between the (log of the) two series is stationary. Without removing the trend the median correlation is about 0.9 , which highlights that our approximation also captures well the low frequency behavior of the terms of trade.
} 
Table 2: Descriptive Statistics

\begin{tabular}{|c|c|c|c|c|c|c|c|c|}
\hline & $\operatorname{Corr}\left(T o T, T o T^{o}\right)$ & $\sigma\left(P^{x}\right)$ & $\gamma_{1}\left(P^{x}\right)$ & $\sigma\left(P^{m}\right)$ & $\gamma_{1}\left(P^{m}\right)$ & $\operatorname{Corr}\left(P^{x}, P^{m}\right)$ & $\sigma(T o T)$ & $\gamma_{1}(T o T)$ \\
\hline Algeria & 90.5 & 31.6 & 67.5 & 6.3 & 72.8 & 27.6 & 30.4 & 71.0 \\
\hline Argentina & 38.8 & 12.8 & 65.0 & 4.7 & 69.8 & 91.5 & 8.6 & 60.7 \\
\hline Bangladesh & 81.2 & 3.4 & 60.4 & 8.5 & 70.2 & 54.2 & 7.2 & 75.0 \\
\hline Bolivia & 67.7 & 17.7 & 66.8 & 5.8 & 71.8 & 68.7 & 14.3 & 69.4 \\
\hline Brazil & 49.0 & 11.2 & 66.6 & 8.6 & 65.6 & 90.6 & 5.0 & 60.7 \\
\hline Burkina Faso & 82.8 & 17.1 & 66.4 & 6.3 & 64.5 & 71.9 & 13.3 & 65.2 \\
\hline Cameroon & 39.6 & 21.4 & 64.9 & 8.1 & 64.2 & 78.9 & 15.8 & 67.9 \\
\hline Chad & 64.5 & 26.5 & 57.6 & 5.0 & 74.6 & 80.8 & 22.7 & 52.6 \\
\hline Colombia & 91.0 & 18.1 & 61.1 & 4.8 & 66.7 & 71.6 & 15.0 & 59.0 \\
\hline Congo, Dem. Rep. & 61.2 & 16.4 & 59.7 & 6.4 & 66.3 & 80.6 & 11.9 & 57.6 \\
\hline Cote d'Ivoire & 38.0 & 14.0 & 63.0 & 10.1 & 58.5 & 71.1 & 9.9 & 49.2 \\
\hline Dominican Republic & 10.2 & 9.3 & 47.4 & 6.3 & 66.0 & 50.9 & 8.2 & 43.1 \\
\hline Egypt, Arab Rep. & 45.3 & 17.3 & 58.9 & 8.6 & 69.0 & 53.8 & 14.6 & 65.5 \\
\hline Equatorial Guinea & 59.1 & 27.6 & 59.8 & 4.5 & 62.5 & 57.3 & 25.3 & 58.5 \\
\hline Gabon & 72.4 & 28.8 & 61.9 & 5.1 & 75.9 & 45.1 & 26.8 & 63.0 \\
\hline Ghana & 74.5 & 15.3 & 62.2 & 6.8 & 67.4 & 80.5 & 10.7 & 55.2 \\
\hline Guatemala & 58.7 & 10.9 & 61.7 & 6.8 & 63.3 & 75.8 & 7.3 & 45.1 \\
\hline Honduras & 55.3 & 7.5 & 51.4 & 7.4 & 75.0 & 71.4 & 5.6 & 33.0 \\
\hline India & 58.7 & 7.1 & 68.4 & 11.3 & 61.8 & 91.3 & 5.6 & 56.3 \\
\hline Indonesia & 82.6 & 14.9 & 67.5 & 9.8 & 69.6 & 79.1 & 9.3 & 77.5 \\
\hline Jordan & 39.3 & 12.0 & 53.7 & 7.9 & 67.0 & 91.2 & 5.8 & 26.0 \\
\hline Kenya & 31.9 & 11.8 & 63.5 & 8.3 & 61.4 & 74.4 & 7.9 & 42.6 \\
\hline Madagascar & 21.8 & 10.5 & 51.5 & 6.0 & 71.1 & 74.2 & 7.2 & 41.7 \\
\hline Malawi & 52.8 & 10.9 & 70.5 & 6.1 & 68.1 & 66.9 & 8.2 & 51.9 \\
\hline Mauritius & 26.2 & 17.1 & 58.6 & 5.9 & 60.4 & 46.4 & 15.3 & 54.9 \\
\hline Mexico & 95.7 & 7.8 & 59.3 & 4.2 & 69.3 & 43.4 & 7.1 & 68.5 \\
\hline Morocco & 35.1 & 9.7 & 61.2 & 8.0 & 63.3 & 89.8 & 4.3 & 48.5 \\
\hline Niger & 21.5 & 12.3 & 66.1 & 6.8 & 78.2 & 31.0 & 12.1 & 75.9 \\
\hline Nigeria & 93.5 & 33.2 & 62.7 & 6.7 & 75.9 & 57.4 & 29.8 & 63.7 \\
\hline Pakistan & 59.1 & 6.2 & 66.3 & 10.3 & 62.7 & 59.6 & 8.3 & 69.5 \\
\hline Peru & 70.0 & 18.8 & 72.5 & 8.1 & 71.1 & 94.7 & 11.4 & 67.1 \\
\hline Philippines & 58.5 & 5.6 & 44.5 & 5.6 & 53.3 & 51.5 & 5.5 & 43.5 \\
\hline Senegal & 23.8 & 13.2 & 61.6 & 9.1 & 60.4 & 92.6 & 5.8 & 54.7 \\
\hline South Africa & 74.1 & 13.1 & 73.0 & 6.4 & 65.4 & 93.5 & 7.5 & 73.5 \\
\hline Sudan & 75.0 & 20.7 & 66.2 & 5.7 & 58.9 & 80.6 & 16.5 & 64.8 \\
\hline Thailand & 41.2 & 7.9 & 58.0 & 8.1 & 63.5 & 66.9 & 6.5 & 51.8 \\
\hline Turkey & 13.0 & 6.3 & 60.4 & 7.5 & 67.7 & 81.7 & 4.3 & 63.5 \\
\hline Uruguay & 82.2 & 9.7 & 67.6 & 9.5 & 66.1 & 67.2 & 7.8 & 74.6 \\
\hline Median & 58.7 & 12.9 & 62.0 & 6.7 & 66.4 & 71.7 & 8.4 & 58.9 \\
\hline Share of PC \#1 & & 73.9 & & 90.2 & & & 65.9 & \\
\hline
\end{tabular}

Notes: $\sigma$ denotes standard deviation, $\gamma_{1}$ is the first order autocorrelation, Corr denotes correlation. All entries are in percentage terms and variables are calculated as the quadratically detrended logarithm of the original data to remove low frequency trends. Therefore, the standard deviations are the standard deviation of the percentage deviations of the series from the trends.

literature (see Cashin et al., 2004; Bidarkota and Crucini, 2000). As the name suggests, it is based on commodity trade shares and associated prices only. ${ }^{11}$ Figure 3 plots the official measure of the terms of trade, the commodity terms of trade, and our measure for two countries in our sample, Sudan and Peru. For Sudan, it is clear that there is a measurement issue since $T o T^{o}$ is constant for about 18 years. ${ }^{12}$ In the case of Peru, we observe that $T o T^{o}$ and $T o T$ comove for the entire period. By contrast, when we consider $T o T^{c}$ we observe that the significant deterioration in the terms of trade observed in the mid 1980s both in $T o T^{o}$ and ToT is attenuated using this metric.

More broadly, not accounting for the share of manufacturing overstates the volatility of export and import prices, particularly the latter, since they are more manufacturing intensive. This is illustrated in Table 3. The first column shows the median ratio of the volatility of the commodity export price $P_{c}^{x}$ and our export price $P^{x}\left(\sigma\left(P_{c}^{x}\right) / \sigma\left(P^{x}\right)\right)$ while the second column reports the same information for import prices $\left(\sigma\left(P_{c}^{m}\right) / \sigma\left(P^{m}\right)\right)$. In all countries, $P_{c}^{x}\left(P_{c}^{m}\right)$ is more volatile than $P^{x}\left(P^{m}\right)$ but the median value of the volatility ratio is 1.48 for export prices and 2.87 for import prices. Interestingly, when we compare the ratio of the volatility

\footnotetext{
${ }^{11}$ Note that Cashin et al. (2004) use only nonfuel primary commodities.

${ }^{12}$ This period coincides with the Second Sudanese Civil War.
} 
Figure 3: Terms of Trade Measures: A Comparison
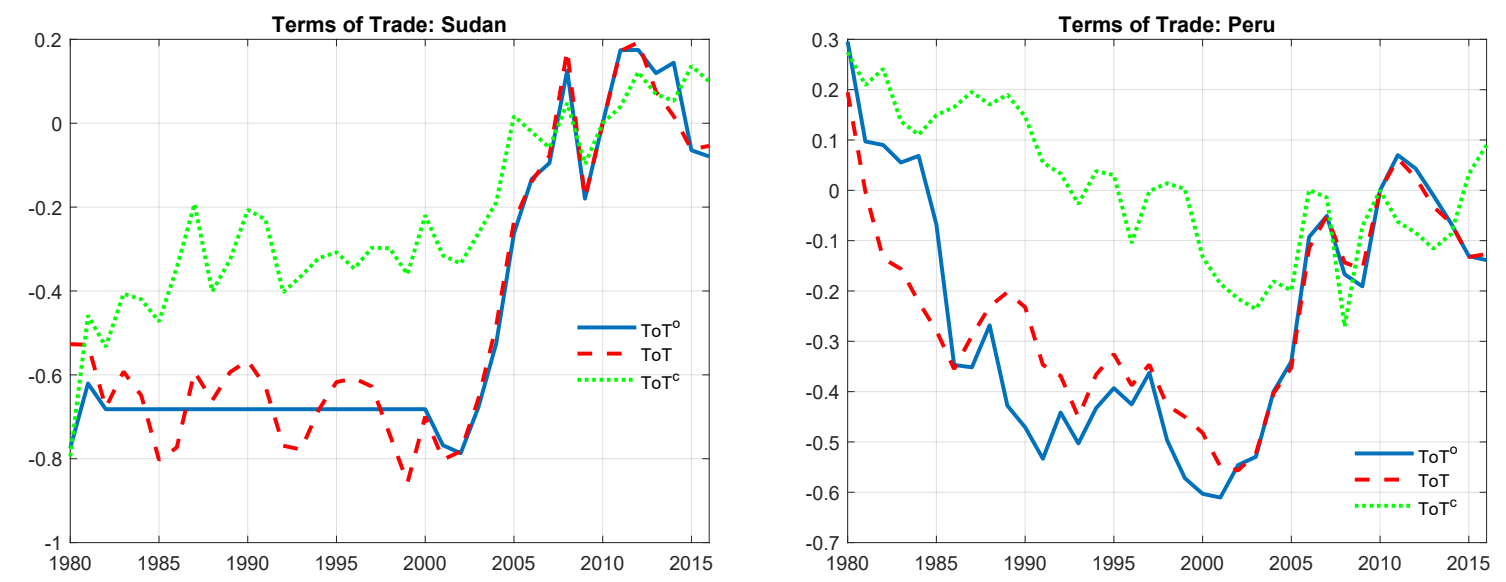

Notes: This Figure shows the evolution of alternative measures of terms of trade for Sudan and Peru over the period 1980-2016. ToT $T^{o}$ is the (log) official measure of terms of trade sourced from WDI, ToT is the (log) measure of terms of trade that we compute using our own export and import price indices, and $T o T^{c}$ denotes $(\mathrm{log})$ commodity terms of trade. Each of the terms of trade measures are normalized to equal zero (i.e. one in levels) in 2010.

Table 3: Commodity Terms of Trade: Descriptive Statistics

\begin{tabular}{lccc}
\hline \hline & $\sigma\left(P_{c}^{x}\right) / \sigma\left(P^{x}\right)$ & $\sigma\left(P_{c}^{m}\right) / \sigma\left(P^{m}\right)$ & $\sigma\left(\right.$ ToT $\left.^{c}\right) / \sigma(T o T)$ \\
\cline { 2 - 4 } Median & 1.48 & 2.87 & 0.8 \\
\# countries $>1$ & 38 & 38 & 12 \\
\hline \hline
\end{tabular}

\begin{abstract}
Notes: $\sigma$ denotes standard deviation; $P_{c}^{x}\left(P_{c}^{m}\right)$ and $P^{x}\left(P^{x}\right)$ are the commodity export (import) price and our export (import) price indices, respectively; $T o T^{c}$ is the commodity terms of trade measure while $T o T$ is the terms of trade measure calculated using our export and import price indices. All entries are in percentage terms and variables are calculated as the quadratically detrended logarithm of the original data to remove low frequency trends. Therefore, the standard deviations are the standard deviation of the percentage deviations of the series from the trends.
\end{abstract}

between $T o T^{c}$ and $T o T\left(\sigma\left(T o T^{c}\right) / \sigma(T o T)\right)$, we find that the volatility $T o T^{c}$ is instead larger than the one for $T o T$ in only 12 countries, with a median value of 0.8 . This happens because $P^{x}$ and $P^{m}$ are dominated by a few commodity prices and are highly correlated, which yields larger fluctuations in the numerator and denominator that cancel out. Table A.4 in Appendix A presents the descriptive statistics on a country-by-country basis.

To sum up, our measure is based on actual world prices and is less prone to measurement issues. Moreover, including the price of manufacturing goods is essential to recover the volatility and persistence of export and import prices to appropriately identify $P^{x}$ and $P^{m}$ shocks and their contribution to the economy.

\title{
2.5 A First Glance at the Data
}

Table 2 summarizes the main descriptive statistics for export and import prices data by country. In particular, it shows the correlation between our constructed measure of terms of trade and the official measure; the standard deviation $(\sigma)$ and the persistence (measured as the first order autocorrelation, $\gamma_{1}$ ) of export prices, import prices and the terms of trade; and the correlation between export and import prices. At the end of the table we report the median 
value of each measure and also the share of variance of export prices, import prices and the terms of trade that we are able to explain with the first principal component of the series. All the variables are calculated as the quadratically detrended log of the original data. ${ }^{13}$

Three important observations stand out from this table. First, export prices are more volatile than import prices in all countries except five. The countries exhibiting more volatile import prices are generally those with a high commodity import share. ${ }^{14}$ Second, export prices and import prices are highly correlated. Therefore, the volatility of the terms of trade is, on average, smaller than the volatility of export prices. Given these characteristics of the data, it is possible that the individual effects of export and import price shocks on macroeconomic variables would dissipate if we only look at their ratio, as defined by the terms of trade. This high correlation could be partly driven by world disturbances, such as global economic activity shocks, which could simultaneously move export and import prices in the same direction. Third, export prices and import prices are more persistent than the terms of trade.

The last row of the table shows the percentage of the variability of export prices, import prices and the terms of trade that we are able to explain with the first principal component. We observe that despite the heterogeneity in the individual countries' trade shares, the first principal component explains 74 percent of the variation in export prices and 90 percent in the variation in import prices. However, when we take the ratio of the export and import price indices to compute the terms of trade, the explanatory power of the first principal component is attenuated as it only explains 66 percent in the variation of the terms of trade. This is consistent with the idea that the impact of common shocks are dampened when using a single price measure. Even though the first principal components of export and import prices are very similar, with a correlation of about 0.9 , the first principal component of the terms of trade is very different. ${ }^{15}$

In Table 4 we analyze the determinants of the volatility in export and import prices. To this aim, we regress the volatility of export and import prices on key variables which are averaged by country across the period analyzed. The regressors are the commodity export share; dummy variables which are equal to 1 if a country is an exporter or importer of agriculture, energy or metals; and the Herfindahl index of concentration calculated both for all goods and for all commodities. The first Panel of Table 4 reports the results for export prices. A higher commodity export share and higher export concentration are associated with higher volatility of export prices. Countries which are energy exporters exhibit, on average, a higher volatility of export prices. By contrast, countries which are agriculture exporters exhibit, on average, a lower volatility in export prices (although the coefficient is rather small). The second Panel of Table 4 shows the results for import prices. As in the case for exports, a higher commodity import share is associated with higher import price volatility. The coefficient on the energy importers dummy is insignificant but the one for agriculture importers dummy is negative and significant, which suggests that these group of countries have, on average, a lower volatility of import prices.

To sum up, given that countries' commodity export shares are much larger than import shares and that the volatility of export prices is higher than that of import prices, the economy may respond differently to $P^{x}$ and $P^{m}$ shocks. Since commodity price exports and imports are highly correlated, by looking at the effects of $T o T$ shocks we may be missing the important role played by world shocks. In addition, we observe that the explanatory power of the first

\footnotetext{
${ }^{13}$ The results are robust to detrending using the HP filter or 2-year growth rates as suggested by Hamilton (2018).

${ }^{14}$ The countries that exhibit the highest volatility in export prices are Algeria, Nigeria, and Equatorial Guinea. Interestingly, what these countries have in common is that crude oil is their main commodity export. By contrast, the highest volatility in import prices is present in Cote d'Ivoire, India and Pakistan, which do not share a similar import pattern since their main commodity imports are cocoa, food, and rice, respectively.

${ }^{15} \mathrm{We}$ do not show these results to preserve space they they are available upon request.
} 
Table 4: Determinants of the Volatility of Export and Import Prices

\begin{tabular}{|c|c|c|c|c|c|c|c|c|c|}
\hline \multirow[b]{2}{*}{ Commodity Export Share } & \multicolumn{4}{|c|}{$\sigma\left(P^{x}\right)$} & \multirow[b]{2}{*}{ Commodity Import Share } & \multicolumn{4}{|c|}{$\sigma\left(P^{m}\right)$} \\
\hline & $\begin{array}{r}.232^{* * *} \\
(0.032)\end{array}$ & $\begin{array}{r}0.179^{* * *} \\
(0.034)\end{array}$ & $\begin{array}{r}0.152^{* * *} \\
(0.038)\end{array}$ & $\begin{array}{r}0.132^{* * *} \\
(0.030)\end{array}$ & & $\begin{array}{r}0.228^{* * *} \\
(0.020)\end{array}$ & $\begin{array}{r}0.224^{* * *} \\
(0.022)\end{array}$ & $\begin{array}{r}0.185^{* * *} \\
(0.040)\end{array}$ & $\begin{array}{r}0.216^{* * *} \\
(0.019)\end{array}$ \\
\hline Agricultural Exporters & & $\begin{array}{r}-0.030^{* *} \\
(0.014)\end{array}$ & $\begin{array}{r}-0.012 \\
(0.014)\end{array}$ & $\begin{array}{r}-0.011 \\
(0.012)\end{array}$ & Agricultural Importers & & $\begin{array}{r}-0.010^{* * *} \\
(0.003)\end{array}$ & $\begin{array}{r}-0.010^{* * * *} \\
(0.003)\end{array}$ & $\begin{array}{r}-0.008^{* *} \\
(0.003)\end{array}$ \\
\hline Energy Exporters & & $\begin{array}{r}0.059^{* * *} \\
(0.017)\end{array}$ & $\begin{array}{r}0.056^{* * *} \\
(0.014)\end{array}$ & $\begin{array}{r}0.057^{* * *} \\
(0.014)\end{array}$ & Energy Importers & & $\begin{array}{r}0.009^{* *} \\
(0.004)\end{array}$ & $\begin{array}{r}0.014^{* *} \\
(0.006)\end{array}$ & $\begin{array}{r}0.006 \\
(0.005)\end{array}$ \\
\hline Metals Exporters & & $\begin{array}{r}-0.009 \\
(0.023)\end{array}$ & $\begin{array}{r}0.015 \\
(0.021)\end{array}$ & $\begin{array}{r}0.023 \\
(0.019)\end{array}$ & & & & & \\
\hline H Index Exports (all goods) & & & $\begin{array}{r}0.121^{* *} \\
(0.047)\end{array}$ & & H Index Imports (all goods) & & & $\begin{array}{l}-0.236 \\
(0.185)\end{array}$ & \\
\hline H Index Exports (all commodities) & & & & $\begin{array}{r}0.139^{* * *} \\
(0.038)\end{array}$ & H Index Imports (all commodities) & & & & $\begin{array}{r}0.069 \\
(0.049)\end{array}$ \\
\hline$R^{2}$ & 0.590 & 0.764 & 0.822 & 0.841 & $R^{2}$ & 0.698 & 0.801 & 0.811 & 0.810 \\
\hline
\end{tabular}

Notes: $\sigma$ denotes standard deviation; the commodity export and import shares are the same as the ones reported in Table 1; agriculture, energy, and metal exporters or importers denote dummy variables which are equal to 1 if the country falls into these categories; the $\mathrm{H}$ index is the Herfindahl index of concentration which can take values from 0 to 1 and it is calculated both for all goods and all commodities separately. In all columns the total number of observations is $38 . *, * *$, and $* * *$ denote significance at the $10 \%, 5 \%$ and $1 \%$ levels, respectively.

principal component is reduced for the terms of trade in comparison to export and import prices, which suggests that some information may be lost by taking the ratio of both prices. These patterns that we observe in the data provide a motivation for our baseline analysis.

\subsection{Impact of Terms of Trade on the Economy}

In this section we present some preliminary evidence to further motivate the empirical exercise that follows. It is well know that terms of trade are difficult to measure. In particular, those from developing countries can be subject to substantial statistical errors. One of the contributions of this paper is to build a comprehensive data set of country-specific export and import prices which we use to construct our own measure of terms of trade. In Table 2 we have documented that while our $T o T$ tend to be strongly correlated with $T o T^{\circ}$, the two measures remain different and for some countries the difference can be quite large. This leads us to believe that some non-trivial measurement issues could be playing a role in the results. In fact, it is possible that the "terms of trade disconnect puzzle" (Schmitt-Grohé and Uribe, 2018) could, at least in part, be explained by the poor measurement of terms of trade in the official statistics. We therefore investigate if the "disconnect" is driven by a measurement issue. In addition, we use the data to test some terms of trade restrictions which point at the importance of analyzing export and import prices separately.

\subsubsection{It's not just measurement}

The scatter plot in Figure 4 compares the one-year ahead forecast error variance decomposition for output driven by terms-of-trade shocks using the official measure (x-axis) vis-à-vis our measure ( $y$-axis). Note that most entries in Figure 4 are below the diagonal, which means that the forecast error variance decomposition of our ToT measure is larger than the one that uses the official $T o T^{\circ}$. However, in line with Schmitt-Grohé and Uribe (2018), we still find that on average, terms-of-trade shocks explain about 10 percent of the factor error variance decomposition of output for both measures. ${ }^{16}$ The same result holds when we do this exercise on the other macro variables. This suggests that a single measure of world prices like the terms of trade provides insufficient information to uncover the channels through which global shocks are transmitted to the economy.

\footnotetext{
${ }^{16}$ Each country is weighted according to their GDP (PPP).
} 
Figure 4: Forecast Error Variance Decomposition: $T o T$ and $T o T^{\circ}$ Shocks

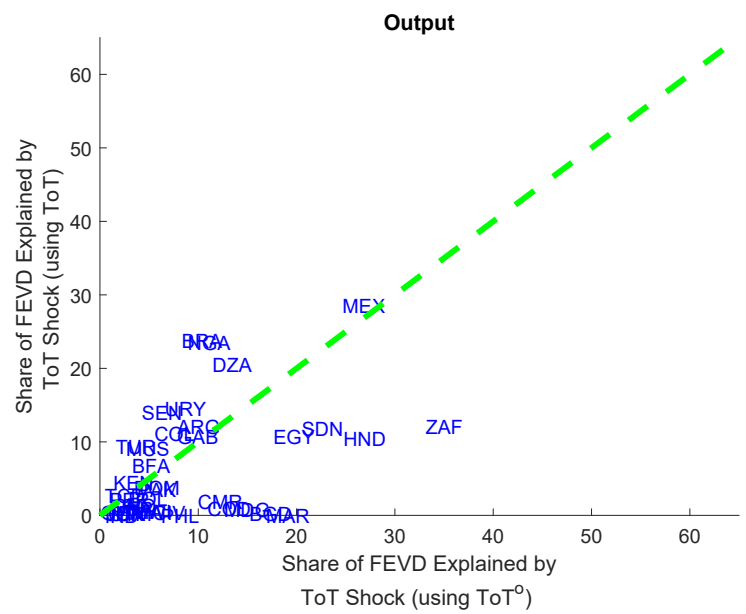

Notes: The Figure compares the one-year ahead forecast error variance decomposition of output, for each country, obtained using the official measure of the terms of trade ( $x$-axis) vis-à-vis our measure computed as the ratio between export and import prices ( $y$-axis).

Table 5: Testing Terms of Trade Restrictions

\begin{tabular}{cccccc}
\hline \hline & Output & Consumption & Investment & Trade Balance & Real Exchange Rate \\
& $(1)$ & $(2)$ & $(3)$ & $(4)$ & $(5)$ \\
\hline F-test & 9.29 & 5.57 & 12.9 & 6.73 & 35.38 \\
& $(0.000)^{* * *}$ & $(0.004)^{* *}$ & $(0.000)^{* * *}$ & $(0.001)^{* *}$ & $(0.000)^{* * *}$ \\
\hline \hline
\end{tabular}

Notes: This table reports the results of the $F$-test for the Hypothesis. p-values in parenthesis. *,**, and $* * *$ denote significance at the $10 \%, 5 \%$ and $1 \%$ levels, respectively.

\subsubsection{Terms of Trade Restrictions}

Empirical models of the terms of trade are postulated on the untested assumption that a shift in the price of exports impacts the economy exactly in the same way as a shift in the price of imports, with an opposite sign. In other words, a simultaneous increase of the same magnitude in the price of exports and imports has no impact on the aggregate economy, as it leaves the terms of trade unaffected. Having constructed separate proxies for the price of exports and imports, this is a prediction that we can now test on the data. In particular, for each variable of interest in the data set, we run the following regression in a panel framework: ${ }^{17}$

$$
x_{i k, t}=a_{0}+a_{1} x_{i k, t-1}+\sum_{j=0}^{1} b_{j}^{x} P_{k, t-j}^{x}+\sum_{j=0}^{1} b_{j}^{m} P_{k, t-j}^{m}+D_{k}+v_{i k, t},
$$

where $x_{k i, t}$ is the log of the variable of interest $i$ (quadratically detrended) for country $k$ in year $t ; P_{k, t}^{x}$ and $P_{k, t}^{m}$ are the log of export and import prices (quadratically detrended) for country $k$ at time $t$, respectively; and $D_{k}$ is a country fixed effect. Robust standard errors are adjusted for clustering at the country-year level. Noting that $T o T_{k, t}=P_{k, t}^{x}-P_{k, t}^{m}$ the regression above becomes particularly convenient to test the hypothesis that a positive shift in terms of trade has the same impact on the economy whether it originates from a positive shift in the price of exports or to a negative shift in the price of imports. This restriction can be written as:

\footnotetext{
${ }^{17}$ The panel structure allows us to increase the power of the test we perform to evaluate the restrictions.
} 


$$
H_{0}: b_{j}^{x}=-b_{j}^{m} \text { for } j=0,1 .
$$

Table 5 shows the results of the $F$-test for this hypothesis for each variable of interest. In all cases we reject the null hypothesis, which motivates the independent analysis of export and import prices. Overall, our analysis is consistent with the idea that a single measure of world prices like the terms of trade provides insufficient information to uncover the channels through which world shocks are transmitted to the economy (Fernández et al., 2018) and calls for an empirical framework that allows us to separately identify independent components of terms-of-trade shocks, reflecting shifts in the price of exports and price of imports. We turn to this in the next section.

\section{Econometric Method}

We follow the practice of the empirical literature on terms-of-trade shocks (see e.g. SchmittGrohé and Uribe, 2018), as well as the theoretical studies (see e.g. Mendoza, 1995), and impose a standard "small open economy" assumption which implies that there is no impact from the current or lagged country specific macroeconomic variables to the "foreign block" of variables, $\mathbf{z}_{k, t}=\left[Y_{t}^{g}, P_{k, t}^{x}, P_{k, t}^{m}\right]^{\prime}$. Therefore, the impact of the three shocks of interest, $\mathbf{u}_{k, t}$, to the "foreign block" of variables can be recovered from the following structural VAR, which we estimate country-by-country: ${ }^{18}$

$$
\mathbf{z}_{k, t}=\mathbf{a}_{k}+\mathbf{A}_{1 k} \mathbf{z}_{k, t-1}+\mathbf{A}_{0 k}^{-1} \mathbf{u}_{k, t},
$$

where $\mathbf{A}_{0 k}^{-1}$ captures the contemporaneous impulse response of the shocks to the foreign block and $\mathbf{u}_{k, t} \sim N(0, I)$. In the next subsection we describe the identification restrictions used to identify the structural shocks in equation (4). In order to retrieve the impact of the shocks $\mathbf{u}_{k, t}$ to the macroeconomic variables of each country we use a simple regression approach in line with Kilian $(2008,2010)$.

Let us define $x_{i k, t}$ as a generic country-specific variable where each $i$ denotes a different macroeconomic aggregate of interest, defined as $Y, C, I, R E R$, and $T B$. The exogeneity of the "foreign block" of variables implies that we can consistently estimate the impact of these variables to the generic country-specific variable, $x_{i k, t}$, using a simple regression approach:

$$
x_{i k, t}=\rho_{0 k}+\rho_{1 k} x_{i k, t-1}+\gamma_{0 k} \mathbf{z}_{k, t}+\gamma_{1 k} \mathbf{z}_{k, t-1}+\varepsilon_{i k, t},
$$

where the structural innovation $\varepsilon_{i k, t}$ is serially uncorrelated (see, e.g., Cooley and LeRoy, 1985). The $1 \times 3$ vector of coefficients $\gamma_{j k}$ captures the impact (including the direct and indirect effects) of a shift in the "global variables" $\mathbf{z}_{k, t}$ (Pesaran and Smith, 2014). Under strict exogeneity, there is no current or lagged feedback from $x_{i k, t}$ to $\mathbf{z}_{k, t}$ and we can retrieve the impact of the shocks of interest onto the macroeconomic variables combining (4) with (5):

$$
x_{i k, t}=c_{0 k}+\gamma_{0 k} \mathbf{A}_{0 k}^{-1} \mathbf{u}_{k, t}+\sum_{j=1}^{\infty} \rho_{1 k}^{-j}\left(\gamma_{0 k}+\gamma_{1} \mathbf{A}_{1 k}\right) \mathbf{A}_{1 k}^{-j} \mathbf{A}_{0 k}^{-1} \mathbf{u}_{k, t-j}+\sum_{j=0}^{\infty} \rho_{1 k}^{-j} \varepsilon_{i k, t} .
$$

Confidence intervals for these impulse responses are constructed by bootstrap methods following Goncalves and Kilian (2004). The single-equation regression approach taken in this paper has three main advantages with respect to specifying a fully fledged VAR with ex-

\footnotetext{
${ }^{18} \mathrm{~A}$ specification with a single lag is the one favored by the data and we use this specification in this section to ease the exposition. The results are unchanged if we allow for a two-lag specification of the model. Note that we are also assuming that the VAR is fundamental and therefore the shocks can be retrieved from orthogonal rotations of the reduced form VAR residuals (Fernández-Villaverde, Rubio-Ramírez, Sargent and Watson, 2007).
} 
ogenous variables for the macroeconomic variables of each single country. First, given that equations (4) and (5) are relatively parsimonious, they have a reduced estimation error on short samples and are also more robust to structural change. Second, given that equation (5) is estimated variable by variable, it can easily handle cases where different variables start (or end) at different years over the estimation sample. Finally, Choi and Chudik (2019) highlight that the iterated approach to recovering impulse responses used in this paper tends to outperform direct approaches, particularly for small samples. At the same time, the specification in equation (6) can retrieve a large variety of shapes for the impulse response functions to the shocks identified.

The estimated responses which we will analyze in Section 4 provide a measure of the expected response of macroeconomic variables to exogenous global shocks based on historical data. They represent consistent estimates of the causal effects of a percentage change in global economic activity, export price, and import price shocks. ${ }^{19}$ Given that that the heterogeneity across countries is important, we estimate the responses country-by-country but, for presentation purposes, we show the mean response weighted by each country's size proxied by their GDP (PPP).

\subsection{Identification}

We identify $P^{x}, P^{m}$ and global economic activity $\left(Y^{g}\right)$ shocks using sign restrictions as in Faust (1998), Canova and De Nicoló (2002), and Uhlig (2005). The advantage of this approach is that the sign restrictions are minimalist and therefore likely to be in line with a wide range of models and beliefs accepted by researchers. However, there are cases in which the sign restrictions method could yield structural parameters with different implications for the impulse responses, elasticities, historical decompositions, or variance decompositions. Some of these may be hard to reconcile with economic theory. In order to limit these cases, we follow Antolín-Díaz and Rubio-Ramírez (2018) and incorporate narrative sign restrictions, which allow us to constrain the structural parameters at the time of salient historical events in such a way that the structural shocks are in line with the selected narrative. ${ }^{20}$

The sign restrictions for each shock are summarized in Table 6 . The sign restrictions for $P^{x}$ and $P^{m}$ shocks are consistent with what are expected to be the responses of domestic output and the real exchange rate to a shift in the terms of trade (see, for example, Schmitt-Grohe and Uribe, 2017, chapter 7). In these models, a positive $P^{x}$ shock would appear as an increase in the terms of trade and a positive $P^{m}$ shock as a decline in the terms of trade. Let us concentrate on the $P^{x}$ shock focusing on the variables for which we imposed a sign restriction (taking into account that a similar reasoning applies in the case of a $P^{m}$ shock). The exchange rate appreciation implies that the country is relatively more expensive with respect to the rest of the world. This happens both through substitution and income effects. An increase in export prices leads to a substitution towards importable and nontraded goods. The increase in export prices also leads to an income effect whereby households become richer and therefore increase their demand for all goods, including nontradables. This pushes nontrable goods prices up, consistent with an exchange rate appreciation. The expansion in the exportable goods and nontradable sectors would typically lead to an increase in GDP.

We leave the response of the trade balance unrestricted because the literature does not give

\footnotetext{
${ }^{19}$ When constructing the export price and import price series, we kept track of the time variation in the exports and import shares. To the extent that changes in those also result from time-varying effects of global shocks into the economy, the impulse responses retrieved should be understood as capturing the average effect of the country-specific endogenous responses that occurred at the time of exogenous global economic activity, export price and import price shocks.

${ }^{20}$ In a related paper, De Winne and Peersman (2016) use narrative restrictions to identify global food commodity price shocks.
} 
an unambiguous prediction for this variable. On the one hand, the Harberger-Laursen-Metzler (HLM) effect would predict that a rise in the terms of trade would improve the trade balance (see Harberger, 1950 and Laursen and Metzler, 1950). On the other hand, the Obstfeld-RazinSvensson (ORS) effect argues that if the positive terms of trade shock is perceived as persistent it could reverse the relation and lead to a deterioration in the trade balance (see Obstfeld, 1982 and Svensson and Razin, 1983). ${ }^{21}$

In order to better disentangle positive shocks to $P^{m}$ vis-à-vis negative shocks to $P^{x}$, we also include restrictions on the absolute relative response of $P^{m}$ and $P^{x}$ to $P^{x}$ and $P^{m}$ shocks (see De Santis and Zimic, 2018). Specifically, we impose that in response to a $P^{x}\left(P^{m}\right)$ shock, the effect of import prices (export prices) on impact, as well and as its peak response, cannot be larger (in absolute value) than the response of export prices (import prices). This restriction limits the possibility of confounding a negative $P^{x}$ shock with a positive $P^{m}$ shock and vice versa. Moreover, with these restrictions we ensure that a positive $P^{x}\left(P^{m}\right)$ shock can be interpreted as a positive (negative) ToT shock. Note that shocks to import or export prices refer to shocks to these prices that are not caused by changes in global demand.

Table 6: Sign restrictions

\begin{tabular}{lccccc}
\hline \hline Shock/Variable & Global GDP & GDP & Price of Exports & Price of Imports & Real Exchange Rate \\
\hline$P^{x}$ & & + & + & & - \\
$P^{m}$ & & - & & + & + \\
$Y^{g}$ & + & + & + & + & \\
\hline \hline
\end{tabular}

Notes: Blank entries denote that no sign restriction is imposed. The sign restrictions are imposed only on impact. We also include relative response restrictions such that the $P^{x}\left(P^{m}\right)$ shock cannot have a larger impact on $P^{m}\left(P^{x}\right)$ both on impact and at its maximum impact.

Global economic activity shocks are included to incorporate any other world shocks that do not directly originate from exogenous shifts in countries' export or import prices. A $Y^{g}$ shock may be driven by unexpected changes in global economic activity. Higher growth triggers an increase in demand for all commodities, which would drive up both export and import prices. This is in line with evidence in Juvenal and Petrella (2015) and Jacks and Stuermer (2018). In addition, a buoyant world economy tends to boost individual country's GDP. They may also capture the impact of fluctuations in global financial conditions on developing countries. Note that from the sign restrictions, a $Y^{g}$ shock could potentially be confounded with a $P^{x}$ shock. Therefore, the narrative restrictions play a crucial role to disentangle the shocks of interest. For each of the countries in the sample, we use the Great Recession as a prototype $Y^{g}$ shock. In particular, we impose that in 2009 the $Y^{g}$ shock is negative and it is the largest contributor to the innovations to global GDP. ${ }^{22}$ Given that this period is associated with large swings in commodity prices, and therefore also import and export prices for the countries under investigation, imposing this narrative restriction reduces the chance that we end up attributing part of the impact of the global recession to export price and import price shocks.

We also impose narrative restrictions to $P^{x}$ and $P^{m}$ shocks by looking at episodes of large exogenous variations of specific commodity prices and link them to each country's series of

\footnotetext{
${ }^{21}$ The idea behind this effect is that households would have incentives to save to smooth consumption if the shock is perceived to be transitory in which case the trade balance would improve given that consumption increases by less than income. However, if the shock is perceived to be persistent, the trade balance would tend to respond less and even turn negative.

${ }^{22}$ Although the start of the global financial crisis is typically dated in September 2008, which coincides with the bankruptcy of Lehman Brothers, we inspect our data on global GDP and the largest contraction in economic activity takes place in 2009. We therefore used 2009 to date the recession. Our results remain robust to using 2008 as an alternative date for the recession.
} 
Table 7: Summary Narrative Restrictions

\begin{tabular}{|c|c|c|c|c|}
\hline Year & Commodity & Sign & Exporters & Importers \\
\hline 1985 & Cereals & - & $\begin{array}{c}\text { ARG, BGD, BFA, CIV, GTM, HND, IND } \\
\text { KEN, MDG, MAR, PAK, PHL, SEN, ZAF } \\
\text { THA, TUR, URY }\end{array}$ & $\begin{array}{l}\text { BRA, BFA, CIV, GTM, HND, IND, JOR } \\
\text { MUS, MEX, NGA, PER, SEN }\end{array}$ \\
\hline 1988 & Cereals & + & $\begin{array}{c}\text { ARG, BGD, BFA, CIV, GTM, HND, IND } \\
\text { KEN, MDG, MAR, PAK, PHL, SEN, ZAF } \\
\text { SDN, THA, TUR, URY }\end{array}$ & $\begin{array}{l}\text { DZA, BGD, BOL, BRA, BFA, CMR, TCD } \\
\text { COD, CIV, DOM, EGY, HND, JOR, MDG } \\
\text { MUS, MAR, NGA, PER, PHL, SEN, SDN }\end{array}$ \\
\hline 1997 & Cereals & - & $\begin{array}{l}\text { ARG, BGD, BFA, CIV, GHA, GTM, HND } \\
\text { IND, KEN, MDG, MAR, PER, SEN, ZAF } \\
\text { SDN, THA, TUR, URY }\end{array}$ & $\begin{array}{l}\text { DZA, BGD, BOL, BRA, BFA, CMR, TCD } \\
\text { COD, CIV, DOM, EGY, GNQ, GAB, GTM } \\
\text { HND, JOR, MDG, MWI, MUS, MAR, NER } \\
\text { PAK, PER, SEN, SDN }\end{array}$ \\
\hline 2010 & Cereals & + & $\begin{array}{c}\text { ARG, BFA, CIV, GHA, GTM, HND, KEN } \\
\text { MDG, MWI, MUS, MAR, PAK, PER, SEN } \\
\text { THA, URY }\end{array}$ & $\begin{array}{c}\text { DZA, BGD, BOL, BFA, CMR, TCD, COL } \\
\text { COD, CIV, DOM, EGY, GAB, GHA, GTM } \\
\text { HND, JOR, MDG, MUS, MAR, NER, NGA } \\
\text { PHL, SEN, SDN }\end{array}$ \\
\hline 2002 & Cocoa & + & GHA & \\
\hline 1986 & Coffee & + & $\begin{array}{l}\text { COL, CIV, DOM, GNQ } \\
\text { GTM, HND, KEN, MDG }\end{array}$ & \\
\hline 1994 & Coffee & + & COL, CIV, GTM, HND, KEN, MDG & \\
\hline 1981 & Copper & - & COD, PER, PHL & \\
\hline 1994 & Cotton & + & BFA, TCD, PAK, SDN & \\
\hline 2003 & Cotton & + & BFA, TCD & \\
\hline 2010 & Cotton & + & BFA & \\
\hline 1986 & Crude oil & - & $\begin{array}{l}\text { DZA, COD, EGY, GAB, IND, IDN } \\
\text { MEX, NGA, PER, TUR }\end{array}$ & $\begin{array}{l}\text { BRA, COL, COD, GNQ, IDN, JOR, MAR } \\
\text { NGA, PAK, PHL, SEN, THA, URY }\end{array}$ \\
\hline 1990 & Crude oil & + & $\begin{array}{l}\text { DZA, CMR, COL, COD, EGY, GAB, IDN } \\
\text { MEX, NGA, PER, TUR }\end{array}$ & $\begin{array}{l}\text { BRA, HND, IND, JOR, KEN, MAR, PAK } \\
\text { PHL, THA, TUR, URY }\end{array}$ \\
\hline 1984 & Fertilizers & + & JOR, MAR, SEN & \\
\hline 1982 & Iron ore & + & BRA, IND & \\
\hline 2000 & Natural gas & + & DZA, BOL & \\
\hline 2005 & Natural gas & + & DZA, BOL, IDN & \\
\hline 1988 & Soybean & + & ARG, BRA & \\
\hline 1984 & Sugar & - & DOM, MWI, MUS, THA & \\
\hline 1993 & Timber & + & BOL, CMR, CIV, GNQ, GAB, GHA & \\
\hline 1989 & Tobacco & + & MWI & \\
\hline 1993 & Tobacco & - & MWI & \\
\hline
\end{tabular}

Notes: The table lists each of the episodes identified as generating large exogenous variations in commodity prices and indicates for which countries it was used as a narrative restrictions to identify export and import price shocks.

export and import prices guided by their trade shares. This was done in three steps. First, we carefully examined Food and Agriculture Organization (FAO) reports, publications from the International Monetary Fund and the World Bank, newspaper articles, academic papers and a number of online sources to identify episodes of substantial commodity price changes that were unrelated to the state of the economy such as natural disasters, weather shocks, or major geopolitical events. A total of 23 episodes were identified and are detailed in Appendix B. Second, we then classified each episode as a negative or positive price shock, depending on the direction of the price change. As a last step, we associate a particular event to a $P^{x}$ $\left(P^{m}\right)$ shock if the export (import) share of the particular country for the specific year and commodity (or commodity group) is larger than 7 percent. ${ }^{23}$ When an event is due to weather conditions or political events of a specific country, we exclude such event for that country. For example, in 1986 there was a large increase (of about 30 percent) in coffee prices caused by droughts in the major producing regions in Brazil. Therefore, this shock was not used as part of the narrative restrictions for Brazil, but was used for other coffee exporters such as Colombia and Guatemala. Appendix B describes each event used in the narrative approach

\footnotetext{
${ }^{23}$ The results remain robust to the use of a different threshold.
} 
Figure 5: Example of Narrative Restrictions
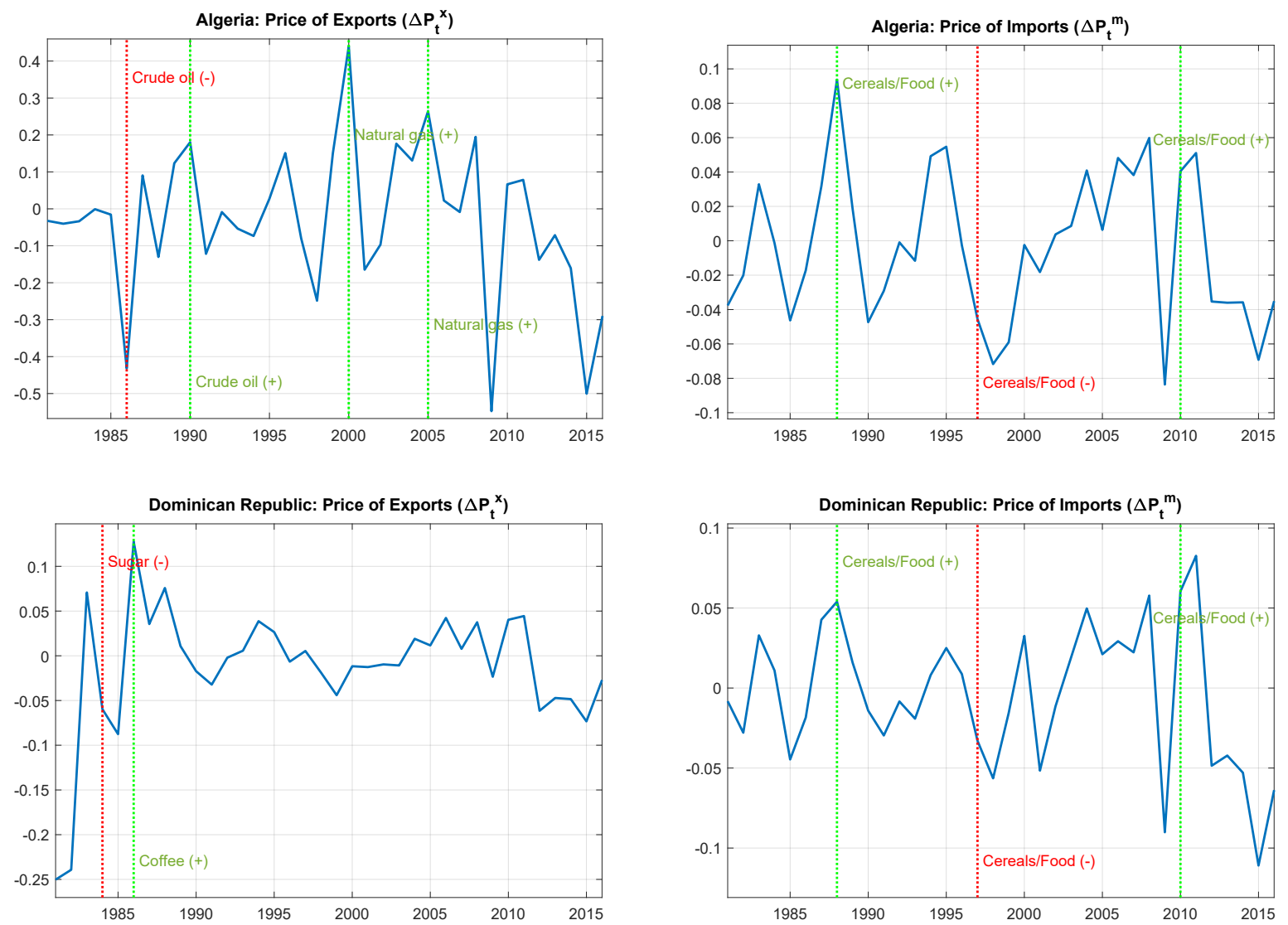

Notes: The figure shows the evolution of the change in export and import prices for Algeria (top panel) and the Dominican Republic (bottom panel) as well as the narrative restrictions (red and green vertical lines).

in detail and summarizes some country-specific assumptions. Table 7 provides a summary of the narrative restrictions imposed.

Despite the fact that the events are commodity specific, whereas $P^{x}$ and $P^{m}$ are a blend of multiple individual prices, the movement of the specific commodity prices around the time of the events are large enough to dominate the variation in export and import prices during that specific year. As an illustration, Figure 5 provides examples for two countries, Algeria and the Dominican Republic. The graphs show the change in export and import prices (in blue) while the vertical lines identify the commodity price episodes for each country. At the time of all the events, we find that $P^{x}$ and $P^{m}$ move in the expected direction, often reflecting spikes in the series. For example, this is the case for the change in $P^{x}$ in the Dominican Republic in 1986 since this country was a coffee exporter although coffee only accounted for 8 percent of exports that year. ${ }^{24}$

\section{Baseline results}

Figure 6 shows the impulse responses to a one standard deviation positive $P^{x}$ shock (in blue) and a one standard deviation negative $P^{m}$ shock (in red). The figures show the mean

\footnotetext{
${ }^{24}$ The charts also highlight that changes in $P^{x}$ and $P^{m}$ tend to be similar for those countries with similar trade specialization. This is the case for the import prices of the two countries in the example given that their import base is dominated by agricultural commodities.
} 
Figure 6: Impulse Responses to an Export and Import Price Shock: All Countries
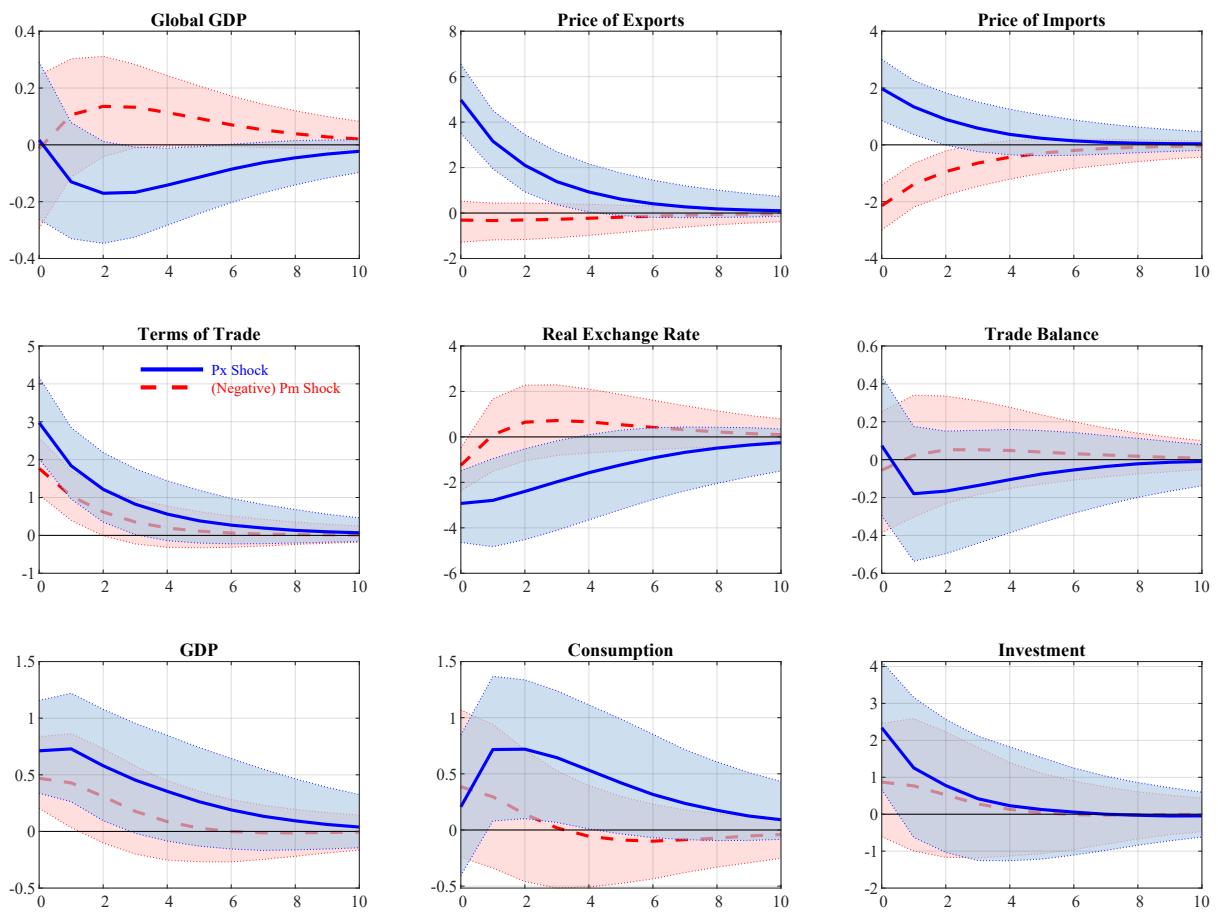

Notes: The figure shows the impulse responses to a positive one standard deviation shock in $P^{x}$ (blue) and negative one standard deviation shock in $P^{m}$ (red) for all countries using a VAR with sign and narrative restrictions. The solid lines denote the mean response weighted by each country's size proxied by their GDP (PPP) and the dashed lines represent the $16^{\text {th }}$ and $84^{\text {th }}$ percentile error bands.

impulse responses weighted by each country's size proxied by their GDP. We observe that an improvement in export prices leads to an increase in domestic GDP, private consumption and investment. In particular, a one standard deviation shock to export prices causes an increase of 0.75 percent of GDP on impact while private consumption increases 0.25 percent. Investment shows a larger expansion (2.3 percent). The terms of trade improve by about 3 percent on impact while the real exchange rate appreciates around 3 percent. The effects on global GDP are negative and small.

The broad comovement of the main macroeconomic aggregates (domestic GDP, consumption and investment) is consistent with a variety of models which emphasize how terms of trade movements are a key source of fluctuation for small open economies (e.g., Mendoza, 1995). In response to a positive terms of trade shock, there can be an income effect whereby households become richer and therefore demand more consumption goods. The improvement in the terms of trade may also boost investment, particularly in the exportable goods sector. The effect of an improvement in the terms of trade on the trade balance is ambiguous from a theoretical point of view. ${ }^{25}$ In the data we do not observe a significant response of the trade balance to a $P^{x}$ shock, which suggests that for some countries the HLM effect is at play while for others the ORS effect is dominating.

From Figure 6 it follows that a one standard deviation shock to import prices leads to a

\footnotetext{
${ }^{25}$ On the one hand, the higher export prices could induce an increase in the production of exportable goods, in which case the trade balance would improve, in line with the HLM effect. On the other hand, if there is a substitution effect from more expensive exportable goods to cheaper importable goods, the trade balance could worsen. In addition, the income effect operating through an increase in consumption could lead to a deterioration in the trade balance. The ORS effect predicts a negative effect of terms of trade improvements on the trade balance.
} 
Table 8: Forecast Error Variance Decomposition

\begin{tabular}{|c|c|c|c|c|c|c|c|c|}
\hline & \multicolumn{2}{|c|}{ Export Prices } & \multicolumn{2}{|c|}{ Import Prices } & \multicolumn{2}{|c|}{ Terms of Trade } & \multicolumn{2}{|c|}{ Real Exchange Rate } \\
\hline & $P^{x}$ & $P^{m}$ & $P^{x}$ & $P^{m}$ & $P^{x}$ & $P^{m}$ & $P^{x}$ & $P^{m}$ \\
\hline 0 & 62.18 & 4.73 & 27.31 & 31.71 & 43.45 & 33.44 & 14.30 & 3.17 \\
\hline 1 & 61.68 & 5.95 & 28.33 & 30.70 & 43.19 & 32.44 & 18.28 & 5.01 \\
\hline 4 & 58.77 & 9.15 & 29.92 & 29.82 & 42.71 & 31.41 & 22.89 & 9.26 \\
\hline \multirow[t]{3}{*}{10} & 57.42 & 10.78 & 31.03 & 29.68 & 42.94 & 31.23 & 24.80 & 11.34 \\
\hline & \multicolumn{2}{|c|}{ Trade Balance } & \multicolumn{2}{|c|}{ Output } & \multicolumn{2}{|c|}{ Consumption } & \multicolumn{2}{|c|}{ Investment } \\
\hline & $P^{x}$ & $P^{m}$ & $P^{x}$ & $P^{m}$ & $P^{x}$ & $P^{m}$ & $P^{x}$ & $P^{m}$ \\
\hline 0 & 8.29 & 7.35 & 12.19 & 7.56 & 8.56 & 6.71 & 10.11 & 4.70 \\
\hline 1 & 11.87 & 9.34 & 17.35 & 10.36 & 14.64 & 9.19 & 12.09 & 7.34 \\
\hline 4 & 16.88 & 12.00 & 22.58 & 13.22 & 22.34 & 12.66 & 15.40 & 10.93 \\
\hline 10 & 18.92 & 13.38 & 24.83 & 14.74 & 24.59 & 14.26 & 17.33 & 12.55 \\
\hline
\end{tabular}

Notes: The table shows the forecast error variance decomposition of all the variables in the VAR for $P^{x}$ and $P^{m}$ shocks on impact, at a 1-year, 2-year, 4-year and 10-year horizons. Reported are mean values weighted by each country's size proxied by their GDP (PPP).

substantially smaller decline in domestic GDP of about 0.4 percent. By contrast, the effects on consumption, investment, and the trade balance are not significant. In addition, the terms of trade deteriorate by about 1.9 percent on impact while the real exchange rate displays a short-lived and partially reversed effect, depreciating about 1 percent on impact. Most importantly, $P^{m}$ shocks are not the mirror image of $P^{x}$ shocks. The asymmetric response of the economy to a $P^{x}$ and $P^{m}$ shocks should not come as a surprise. All the countries under analysis display large differences in terms of of import and export specialization. While exports are concentrated on a few key commodities, imports are more diversified. Therefore, it is expected that $P^{x}$ shocks affect the economy different from $P^{m}$ shocks.

One way to assess the importance of a particular shock in driving business cycles is to compute the variance decomposition. Table 8 shows the share of the variance of all the variables in the VAR explained by $P^{x}$ and $P^{m}$ shocks. As highlighted above, when thinking about terms-of-trade shocks it is important to distinguish their origin, as they are, in general, a combination of $P^{x}$ and $P^{m}$ shocks. Therefore, in order to assess the share of variance explained by terms-of-trade shocks, we look at the joint effect of $P^{x}$ and $P^{m}$ shocks. Some interesting results follow from the Table. First, the estimates indicate that ToT shocks, defined as the combination of $P^{x}$ and $P^{m}$ shocks, account for the largest share of the volatility of the main macroeconomic variables. In particular, they explain from 20 to 40 percent of domestic GDP on impact and at a 10-year horizon, respectively. A similar result is obtained for consumption, where both shocks explain from 15 to 39 percent of its variation on impact and at a 10-year horizon. In addition, $P^{x}$ and $P^{m}$ shocks explain up to 30 percent of investment. Interestingly, the effects of $P^{x}$ shocks tend to be larger than those of $P^{m}$ shocks. For example, $P^{x}$ shocks account for almost twice the volatility of domestic GDP, consumption and the real exchange rate in the long-run. The large role played by $P^{x}$ and $P^{m}$ shocks for real exchange rate fluctuations is related to the findings in Ayres et al. (2020), who show that a large share of real exchange rate volatility is explained by fluctuations in commodity prices. The fact that $P^{x}$ is more important can in part be due to the higher commodity share (and therefore would be consistent with Cashin et al., 2004). This illustrates that these shocks are not transmitted to the economy in the same way. Second, $P^{x}$ shocks have a larger impact on import prices than the reverse because $P^{x}$ shocks tend to have a larger impact on aggregate economic activity than $P^{m}$ shocks. The latter reflect mostly shifts in the price of manufacturing goods (which explain the main bulk of imports). These changes in global economic activity subsequently lead to an increase in import prices.

Appendix C contains the empirical evidence on global economic activity shocks. Our main 
Figure 7: Comparison Forecast Error Variance Decomposition $\left(P^{x}, P^{m}\right.$ and $Y^{g}$ vs. World Shocks)
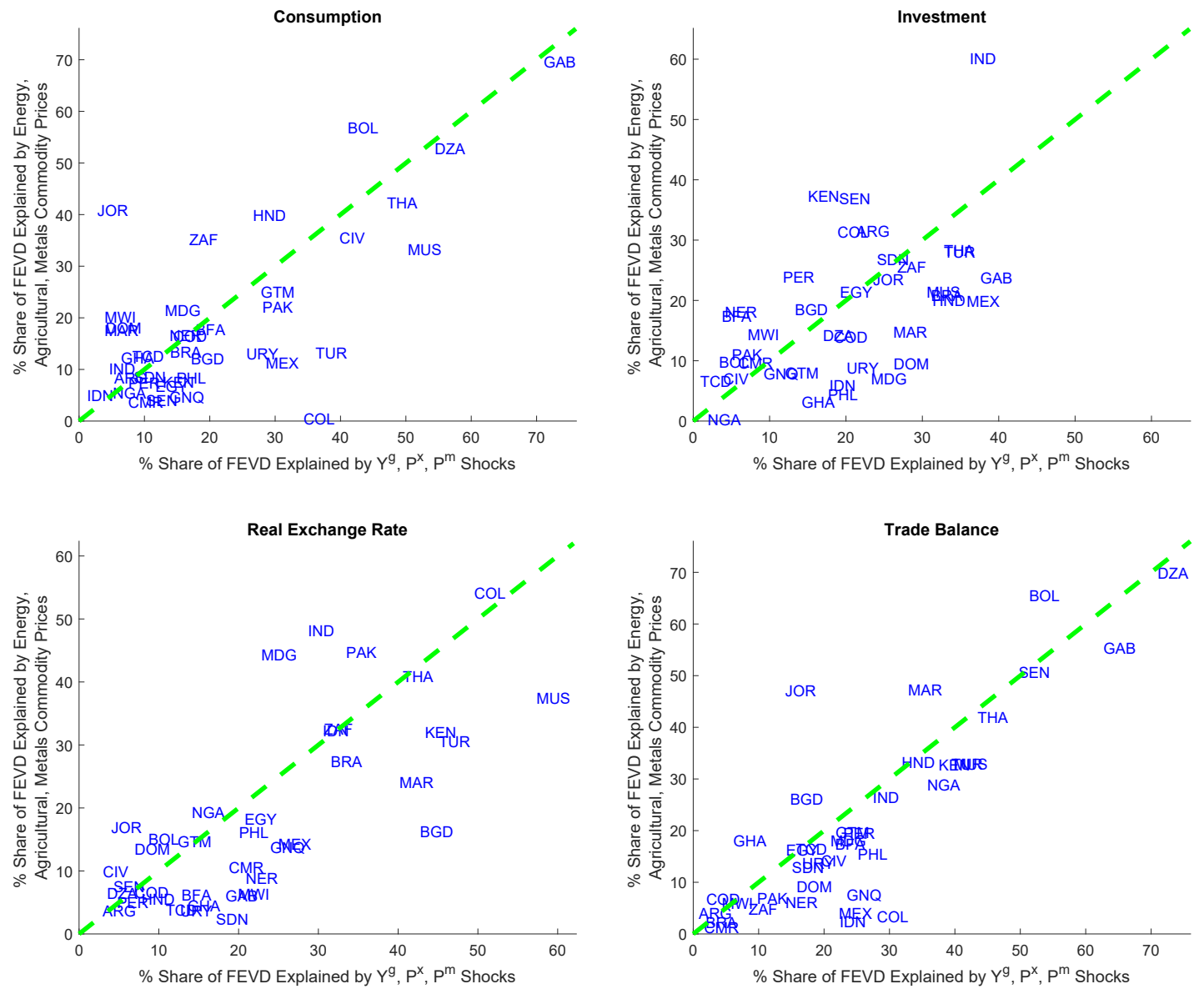

Notes: This Figure shows a comparison of the forecast error variance decomposition of main economic variables, for each country, in our model (x-axis) vis-à-vis Fernández et al. (2017) (y-axis) using our own data and the methodology explained in Section 3.

findings can be summarized as follows. We observe that a positive $Y^{g}$ shock is associated with high-demand pressures which lead to an increase in both export and import prices. This happens because $Y^{g}$ shocks reflect an increase in demand for all industrial commodities triggered by the state of the global business cycle and drive the price of commodities which are bundled into export and import prices upwards. This result is in line with the findings of Juvenal and Petrella (2015) who show that the co-movement between commodity prices is driven by global economic activity shocks. Given that positive global economic activity shocks lead to an increase in both export and import prices, it is not surprising that the impact on the terms of trade is small and actually insignificant at all horizons. These findings highlight our point that world disturbances like a $Y^{g}$ shock would tend to yield a small effect on terms of trade because of the simultaneous increase in export and import prices. However, the effects on the economy could be significant: a $Y^{g}$ shock is associated with a robust increase in GDP, investment and a fall in the real exchange rate. Therefore, our results are also consistent with the presence of other shocks (e.g. financial) playing an important role for the dynamic of the business cycle in developing economies (see, for example, Chang and Fernández, 2013; and Neumeyer and Perri, 2005).

Fernández et al. (2017) show that world shocks, summarized by three commoditiy indices, 
Figure 8: Heterogeneous Effects of $P^{x}$ and $P^{m}$ shocks on Output

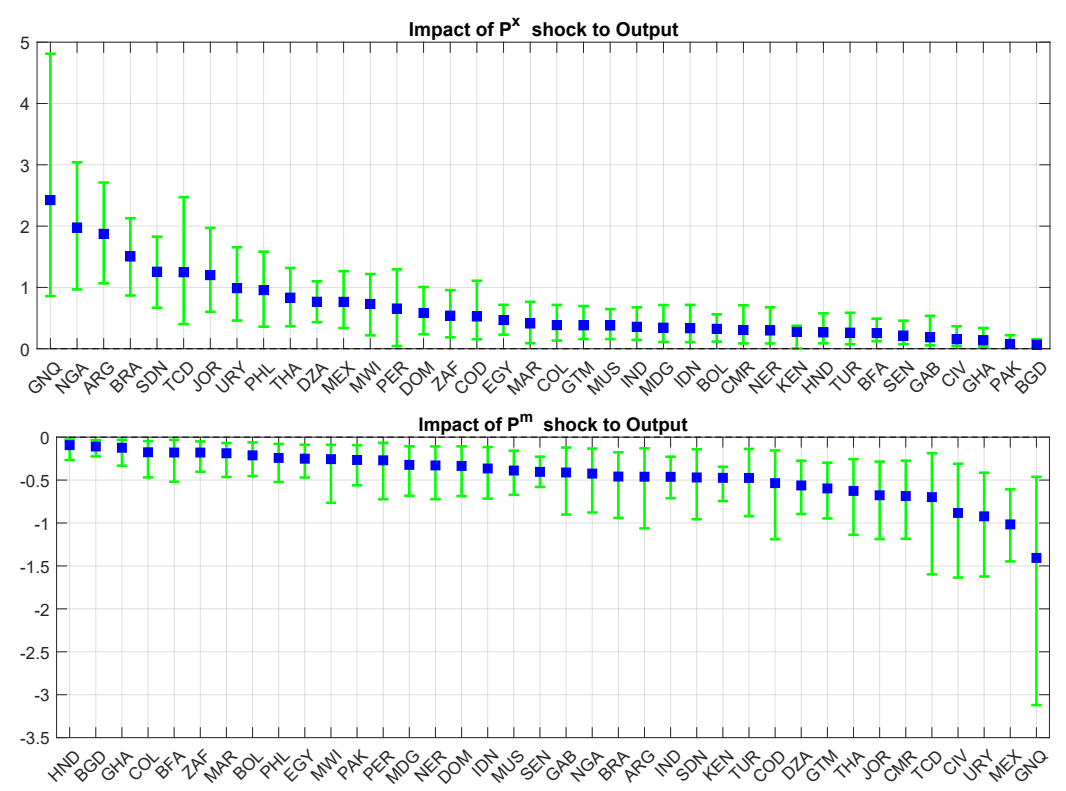

Notes: The figure shows the impact impulse response (blue square) on output (in \%) for each country in the sample to a one standard deviation shock in $P^{x}$ and $P^{m}$. The green lines represent 16 th and 84 th percentile error bands.

matter for business cycle fluctuations. Therefore, the terms of trade do not fully capture the transmission of global shocks to the economy. The scatter plots of Figure 7, which complement those of Figure 1, compare, for each country, the forecast error variance decomposition of consumption, investment, the real exchange rate, and the trade balance in our paper vis-à-vis Fernández et al. (2017). The scatter plots show that our model explains a comparable share of the variance decomposition for the main economic variables. This is not surprising since the three commodity indices in Fernández et al. (2017) overlap with the main commodities that are part of the export and import prices. In addition, commodity prices, and metal prices in particular, are often considered an indicator of global economic activity (see, for example, Caldara, Cavallo, and Iacoviello, 2019).

The plots highlight that for some countries, world shocks are by far the most dominant source of business cycle fluctuations. The advantage of our methodology is that it allows us to characterize the main channels of transmission of world disturbances. We find that ToT shocks, defined as a combination of $P^{x}$ and $P^{m}$ shocks are key to understanding the dynamics of developing countries business cycles. In particular, $P^{x}$ shocks seems to be, on average, more important, especially at longer horizons (i.e. $P^{x}$ shocks have a more persistent effect to the economy).

\subsection{Cross-Country Heterogeneity}

The aggregate results summarized in the previous section mask a great deal of heterogeneity across countries. Figure 8 shows the impact impulse response (blue square) of output, for each country, to a one standard deviation shock in $P^{x}$ and $P^{m}$. A few observations stand out from these charts. First, the effects of $P^{x}$ shocks on output tend to be larger than those stemming from $P^{m}$ shocks. Second, the impact of $P^{m}$ shocks appears to be more homogeneous across countries. Third, with only a few exceptions, the ten countries which exhibit the largest response of output after a $P^{x}$ shock are not the same as those experiencing higher output changes following a $P^{m}$ shock. This highlights that the asymmetric effects of $P^{x}$ and $P^{m}$ 
Table 9: Determinants of the Impulse Responses to $P^{x}$ and $P^{m}$ Shocks

\begin{tabular}{|c|c|c|c|c|c|c|c|c|c|}
\hline \multirow[b]{2}{*}{ GDP Per Capita (PPP) } & \multicolumn{3}{|c|}{ IRF $Y$ to a $P^{x}$ Shock } & \multicolumn{3}{|c|}{ IRF $T B$ to a $P^{x}$ Shock } & \multicolumn{3}{|c|}{ IRF $T o T$ to a $P^{x}$ Shock } \\
\hline & $\begin{array}{c}0.045 \\
(0.068)\end{array}$ & $\begin{array}{c}0.276^{* * *} \\
(0.025)\end{array}$ & $\begin{array}{c}0.276^{* * *} \\
(0.0216)\end{array}$ & $\begin{array}{c}0.002 \\
(0.155)\end{array}$ & $\begin{array}{l}-0.158 \\
(0.325)\end{array}$ & $\begin{array}{c}-0.250^{* * *} \\
(0.085)\end{array}$ & $\begin{array}{c}-0.803 \\
(0.610)\end{array}$ & $\begin{array}{c}-0.418 \\
(0.315)\end{array}$ & $\begin{array}{c}0.132 \\
(0.415)\end{array}$ \\
\hline Commodity Export Share & $\begin{array}{l}-0.001 \\
(0.004)\end{array}$ & $\begin{array}{c}0.005^{* * *} \\
(0.001)\end{array}$ & $\begin{array}{c}0.005^{* * *} \\
(0.001)\end{array}$ & $\begin{array}{c}0.008 \\
(0.006)\end{array}$ & $\begin{array}{c}0.004 \\
(0.004)\end{array}$ & $\begin{array}{c}0.004^{* * *} \\
(0.001)\end{array}$ & $\begin{array}{c}0.071^{* * *} \\
(0.015)\end{array}$ & $\begin{array}{c}0.084^{* * *} \\
(0.013)\end{array}$ & $\begin{array}{c}0.088^{* * * *} \\
(0.0083)\end{array}$ \\
\hline H Index Exports (commodities) & & & $\begin{array}{c}-0.0144 \\
(0.170)\end{array}$ & & & $\begin{array}{c}0.168 \\
(0.239)\end{array}$ & & & $\begin{array}{c}5.638^{* * *} \\
(1.281)\end{array}$ \\
\hline \multirow[t]{2}{*}{ Comm. Groups Dummies } & & $\checkmark$ & $\checkmark$ & & $\checkmark$ & $\checkmark$ & & $\checkmark$ & $\checkmark$ \\
\hline & \multicolumn{3}{|c|}{ IRF $Y$ to a $P^{m}$ Shock } & \multicolumn{3}{|c|}{ IRF $T B$ to a $P^{m}$ Shock } & \multicolumn{3}{|c|}{ IRF $T o T$ to a $P^{m}$ Shock } \\
\hline GDP Per Capita (PPP) & $\begin{array}{l}-0.042 \\
(0.036)\end{array}$ & $\begin{array}{c}-0.157^{* * *} \\
(0.036)\end{array}$ & $\begin{array}{c}-0.151^{* * *} \\
(0.042)\end{array}$ & $\begin{array}{c}0.369^{* * * *} \\
(0.117)\end{array}$ & $\begin{array}{c}0.415^{* * *} \\
(0.047)\end{array}$ & $\begin{array}{c}0.372^{* * *} \\
(0.051)\end{array}$ & $\begin{array}{c}0.158^{* *} \\
(0.065)\end{array}$ & $\begin{array}{l}0.0396 \\
(0.052)\end{array}$ & $\begin{array}{l}0.0276 \\
(0.125)\end{array}$ \\
\hline Commodity Import Share & $\begin{array}{l}-0.002 \\
(0.007)\end{array}$ & $\begin{array}{c}-0.003 \\
(0.003)\end{array}$ & $\begin{array}{l}-0.003 \\
(0.003)\end{array}$ & $\begin{array}{c}0.023^{* * *} \\
(0.006)\end{array}$ & $\begin{array}{c}-0.030^{* * *} \\
(0.006)\end{array}$ & $\begin{array}{c}-0.024^{* * * *} \\
(0.006)\end{array}$ & $\begin{array}{c}-0.045^{* * *} \\
(0.009)\end{array}$ & $\begin{array}{c}-0.150^{* * *} \\
(0.037)\end{array}$ & $\begin{array}{c}-0.148^{* * * *} \\
(0.030)\end{array}$ \\
\hline H Index Imports (commodities) & & & $\begin{array}{c}0.785 \\
(1.238)\end{array}$ & & & $\begin{array}{c}-0.475 \\
(0.669)\end{array}$ & & & $\begin{array}{c}-2.724 \\
(16.100)\end{array}$ \\
\hline Comm. Groups Dummies & & $\checkmark$ & $\checkmark$ & & $\checkmark$ & $\checkmark$ & & $\checkmark$ & $\checkmark$ \\
\hline
\end{tabular}

Notes: The commodity export and import shares are the same as the ones reported in Table 1 ; the $\mathrm{H}$ index is the Herfindahl index of concentration which can take values from 0 to 1 and it is calculated for all commodities; Comm. Group Dummies denote that the regression includes dummy variables which are equal to 1 if the country is an agriculture, energy, and metal exporter or importer. In all columns the total number of observations is 38 and the regression is robust to outliers. *,**, and $* * *$ denote significance at the $10 \%$, $5 \%$ and $1 \%$ levels, respectively.

shocks are not only an aggregate phenomena but also present at the country-level. ${ }^{26}$

In Table 9 we analyze the determinants of the impact impulse responses for output, the trade balance and the terms of trade in response to $P^{x}$ and $P^{m}$ shocks. Specifically, we regress the impact impulse response, defined as a 1 standard deviation shock in $P^{x}$ (or $P^{m}$ ) multiplied by 100 , on key variables which are averaged by countries across the period analyzed so that we perform a cross-sectional estimation robust to outliers. ${ }^{27}$ The regressors are the GDP per capita (PPP), the commodity export (import) share (as reported in Table 1), dummy variables which equal 1 if a country is agriculture, energy or metal exporter (or importer), and the Herfindahl index of concentration.

The upper panel displays the results for the $P^{x}$ shock. The variable that is systematically statistically significant is the commodity export share. The results suggest that countries that have a higher commodity export share exhibit, on average, a larger response of output, the trade balance and the terms of trade in response to a $P^{x}$ shock. We find the response of the terms of trade after a $P^{x}$ shock is larger, on average, for energy exporters as well as for countries that exhibit a higher concentration. In addition, countries with a higher GDP per capita display a larger response of output to a $P^{x}$ shock. The lower panel shows the results for the $P^{m}$ shock. Countries with a higher commodity import share exhibit a smaller response of the terms of trade. The estimation reveals that countries with higher GDP per capita show a smaller response of output in response to a $P^{m}$ shock.

Overall, the results indicate that export characteristics, and in particular the share of commodity exports, are key to understand the cross-sectional differences across countries. The aggregate results mask a great degree of cross-country heterogeneity. Specifically, the impact of global disturbances could be different depending on the pattern of export and import specialization across countries. In the next section we investigate this.

\footnotetext{
${ }^{26}$ Appendix D.1 attends to the heterogeneous effects of $Y^{g}$ shocks on export prices, import prices, and output.

${ }^{27}$ We run this "robust" regression because otherwise outliers in some of the impulse response functions at the country-level can drive the overall results (see Verardi and Croux, 2009). The results are comparable if we analyze the cumulative response or the peak response.
} 


\section{Extensions}

We analyze the effects of $P^{x}, P^{m}$, and $Y^{g}$ shocks by grouping the countries according to whether they are exporters or importers of main commodity groups. For exporters, we split the countries into agriculture (food and beverages), energy, manufacturing, metals and minerals (including precious metals) and agriculture raw materials (plus fertilizers). ${ }^{28}$ For importers, we divide the countries into agriculture (food and beverages), energy, and manufacturing. Details about the sample split as well as the impulse responses by group are presented in Appendix D.2. Two main results stand out: (i) There is heterogeneity in the responses across commodity groups where exporters and importers react differently to each shock; and (ii) within each commodity group $P^{x}$ and $P^{m}$ shocks do not mirror each other. This reinforces the idea that terms-of-trade shocks are not all alike.

Part of the heterogeneity observed in the impulse responses can reflect different patterns of specialization among the different commodity groups (e.g., agricultural production is clearly more labor intensive than energy). We observe that the impact of each shock depends on the commodity group and on whether the country is an exporter or importer of that commodity. The variance decomposition suggests that export price shocks explain the largest share of the variation of output for agriculture and energy exporters while the smallest share of the variance of output pertains to the manufacturing exporters group. Interestingly, the effects of import price shocks on output are more homogeneous across importer groups.

When we look at the responses to a $Y^{g}$ shock for energy exporters and importers we note that this group has a higher elasticity with respect to global economic activity (i.e. these commodity prices move more than the ones in other groups after a global economic activity shock). In both cases, the price response is higher than the one for the whole sample of countries, which implies that export and import prices in countries specialized in energy tend to react more than the average. In both cases the terms of trade tend to move in the same direction as energy prices. Specifically, in the aggregate results for all countries, following a global economic activity shock, the effects on the terms of trade are roughly zero, whereas they move down significantly for energy importers (i.e. they follow the inverse pattern of import prices, that is energy prices). By contrast, for energy exporters the terms of trade go up but the effect is not statistically significant. Interestingly, in response to a global economic activity shock, the trade balance moves in the direction of the terms of trade, consistent with the HLM effect, for energy importers. In particular, the trade balance deteriorates (persistently) for energy importers (Figure D.7, Appendix D) but yields no statistically significant result for energy exporters (Figure D.4, Appendix D). The large effect in the energy commodity groups could be partly related to the fact that exports are very concentrated in the energy commodities, which have a relatively low degree of substitutability.

\section{Conclusion}

Using a data set of commodity and manufacturing prices combined with time-varying sectoral export and import shares we analyze the role of export price, import price, and global economic activity shocks identified combining sign restrictions and a narrative approach.

By breaking down terms-of-trade shocks into export price and import price shocks to study their transmission mechanism, we show that the former is not a mirror image of the latter.

\footnotetext{
${ }^{28}$ We bundled precious metals into the metals category as otherwise we would have no countries in the precious metals exporters category. This happens because precious metals exports do not represent a large enough share of exports. Therefore, we can think of this group as related to mining activity and including both industrial and precious metals. In addition, we included fertilizers into the agriculture raw materials group because otherwise we were left with a very small group on its own.
} 
While the effects of export price shocks seem to generate larger and more persistent effects on macro variables, the impact of import price shocks is more subdued. Taken together, export and import price shocks explain up to 40 percent of output fluctuations and its components in the long run, which is in line with the predictions of a wide range of theoretical models but at odds with recent empirical evidence based on a single commodity price measure (like the terms of trade). Therefore, we argue that the "terms of trade disconnect puzzle" could be partly attributed to the fact that terms-of-trade shocks are not all alike.

Our empirical model allows for an additional world disturbance driven by global economic activity shocks, which is responsible for the documented strong correlation between import and export prices. Given that global economic activity shocks push export and import prices in the same direction, a large fraction of their impact on the underlying prices cancels out if we analyze a single price like the terms of trade.

We extend our baseline analysis to assess how the impact of global disturbances differs depending on the pattern of export and import specialization across countries. Our results highlight that there is substantial heterogeneity. For export price shocks, this heterogeneity is driven by the size of the commodity export share: the larger the commodity export share, the larger the effect of export price shocks on business cycle variables.

Our empirical framework shows that terms-of-trade shocks are important and that their swings can have substantial effects on the economy. A number of implications can be drawn from our results. First, policy makers' concern about fluctuations in the terms of trade seems to be well founded: movements in the terms of trade have substantial effects on business cycle variables. Second, given that a large share of developing country's business cycles is driven by global disturbances, it is important that policies are implemented to mitigate the potential negative impact of these shocks. For example, a country may benefit from running a counter-cyclical fiscal policy during commodity price booms as described in Céspedes and Velasco (2014). Our results highlight that business cycle variables of countries with more concentration in exports in one commodity, such as energy exporters, react more to export price shocks. Therefore, promoting policies aimed at a more diversified export sector could mitigate the disruption generated by terms of trade volatility. Finally, the distinction between export and import price shocks invites the use of a new theoretical framework to think about terms of trade which we leave as part of our future research. 


\section{References}

Alquist, R., S. Bhattarai, And O. Coibion (2020): "Commodity-Price comovement and Global Economic Activity," Journal of Monetary Economics, 112, 41-56.

Antolín-Díaz, J. And J. F. Rubio-Ramírez (2018): "Narrative Sign Restrictions for SVARs," American Economic Review, 108, 2802-2829.

Ayres, J., C. Hevia, And J. P. Nicolini (2020): "Real Exchange Rates and Primary Commodity Prices," Journal of International Economics, 122, 103261.

Bidarkota, P. and M. J. Crucini (2000): "Commodity Prices and the Terms of Trade," Review of International Economics, 8, 647-666.

Caldara, D., M. Cavallo, and M. Iacoviello (2019): "Oil Price Elasticities and Oil Price Fluctuations," Journal of Monetary Economics, 103, 1-20.

Canova, F. And G. De Nicoló (2002): "Monetary Disturbances Matter for Business Fluctuations in the G-7," Journal of Monetary Economics, 49, 1131-1159.

Cashin, P., L. Cespedes, and R. Sahay (2004): "Commodity Currencies and the Real Exchange Rate," Journal of Development Economics, 75, 239-268.

Cavallo, A. And M. Bertolotti (2016): "Filling the Gap in Argentina's Inflation Data Rates," Mimeo.

Céspedes, L. F. And A. Velasco (2014): "Was this Time Different?: Fiscal Policy in Commodity Republics," Journal of Development Economics, 106, 92-106.

Chang, R. And A. Fernández (2013): "On The Sources Of Aggregate Fluctuations In Emerging Economies," International Economic Review, 54, 1265-1293.

Choi, C.-Y. And A. Chudik (2019): "Estimating Impulse Response Functions When the Shock Series is Observed," Economics Letters, 180, $71-75$.

Cooley, T. And S. LeRoy (1985): "Atheoretical Macroeconometrics: A Critique," Journal of Monetary Economics, 16, 283-308.

Daruich, D., W. Easterly, And A. Reshef (2019): "The Surprising Instability of Export Specializations," Journal of Development Economics, 137, 36 - 65.

De Santis, R. A. And S. Zimic (2018): "Spillovers Among Sovereign Debt Markets: Identification Through Absolute Magnitude Restrictions," Journal of Applied Econometrics, 33, $727-747$.

De Winne, J. and G. Peersman (2016): "Macroeconomic Effects of Disruptions in Global Food Commodity Markets: Evidence for the United States," Brookings Papers on Economic Activity, 47, 183-286.

Deaton, A. And R. Miller (1996): "International Commodity Prices, Macroeconomic Performance and Politics in Sub-Saharan Africa," Journal of African Economies, 5, 99-191.

Delle Chiaie, S., L. Ferrara, and D. Giannone (2017): "Common Factors of Commodity Prices," Working papers 645, Banque de France.

Drechsel, T. and S. Tenreyro (2018): "Commodity Booms and Busts in Emerging Economies," Journal of International Economics, 112, 200-218. 
Faust, J. (1998): "The Robustness of Identified VAR Conclusions About Money," International Finance Discussion Paper 610.

Fernández, A., A. González, and D. Rodríguez (2018): "Sharing a Ride on the Commodities Roller Coaster: Common Factors in Business Cycles of Emerging Economies," Journal of International Economics, 111, 99-121.

Fernández, A., S. Schmitt-Grohé, And M. Uribe (2017): "World Shocks, World Prices, and Business Cycles: An Empirical Investigation," Journal of International Economics, 108, $2-14$.

Fernández-Villaverde, J., J. F. Rubio-Ramírez, T. J. Sargent, and M. W. Watson (2007): "ABCs (and Ds) of Understanding VARs," American Economic Review, 97, 10211026 .

Goncalves, S. And L. Kilian (2004): "Bootstrapping Autoregressions with Conditional Heteroskedasticity of Unknown Form," Journal of Econometrics, 123, 89-120.

Hamilton, J. D. (2018): "Why You Should Never Use the Hodrick-Prescott Filter," The Review of Economics and Statistics, 100, 831-843.

Harberger, A. C. (1950): "Currency Depreciation, Income, and the Balance of Trade," Journal of Political Economy, 58, 47-60.

Jacks, D. S. And M. Stuermer (2018): "What Drives Commodity Price Booms and Busts?" Energy Economics.

Juvenal, L. And I. Petrella (2015): "Speculation in the Oil Market," Journal of Applied Econometrics, 30, 621-649.

Kilian, L. (2008a): "A Comparison of the Effects of Exogenous Oil Supply Shocks on Output and Inflation in the G7 Countries," Journal of the European Economic Association, 6, 78121.

(2008b): "Exogenous Oil Supply Shocks: How Big Are They and How Much Do They Matter for the U.S. Economy?" The Review of Economics and Statistics, 90, 216-240.

Kose, M. A. (2002): "Explaining Business Cycles in Small Open Economies: 'How Much do World Prices Matter?'," Journal of International Economics, 56, 299-327.

Kravis, I. B. AND R. Lipsey (1971): Price Competitiveness in World Trade, National Bureau of Economic Research, Inc.

Laursen, S. And L. A. Metzler (1950): "Flexible Exchange Rates and the Theory of Employment," The Review of Economics and Statistics, 32, 281-299.

Mauro, P. And T. I. Becker (2006): "Output Drops and the Shocks That Matter," IMF Working Papers 06/172, International Monetary Fund.

MendozA, E. G. (1995): "The Terms of Trade, the Real Exchange Rate, and Economic Fluctuations," International Economic Review, 36, 101-137.

Neumeyer, P. A. And F. Perri (2005): "Business Cycles in Emerging Economies: the Role of Interest Rates," Journal of Monetary Economics, 52, 345-380.

Obstfeld, M. (1982): "Aggregate Spending and the Terms of Trade: Is There a LaursenMetzler Effect?" The Quarterly Journal of Economics, 97, 251-270. 
Pesaran, M. H. And R. P. Smith (2014): "Signs of Impact Effects in Time Series Regression Models," Economics Letters, 122, 150-153.

Schmitt-Grohé, S. And M. URIBe (2018): "How Important are Terms-of-Trade Shocks?" International Economic Review, 59, 85-111.

Silver, M. (2009): "Do Unit Value Export, Import, and Terms-of-Trade Indices Misrepresent Price Indices?" IMF Staff Papers, 56, 297-322.

Svensson, L. And A. Razin (1983): "The Terms of Trade and the Current Account: The Harberger-Laursen-Metzler Effect," Journal of Political Economy, 91, 97-125.

Uhlig, H. (2005): "What are the Effects of Monetary Policy on Output? Results from an Agnostic Identification Procedure," Journal of Monetary Economics, 52, 381-419.

Verardi, V. And C. Croux (2009): "Robust Regression in Stata," Stata Journal, 9, 439453. 


\section{Appendix A Data}

Our data set includes information on macroeconomic indicators, commodity prices, producer price indices (PPI), and country-specific sectoral export and import shares. This appendix describes the sources of data used in the paper.

\section{A.1 Macroeconomic Data Sources}

The country-specific macroeconomic data are from the World Bank's World Development Indicators (WDI) database. Specific details of these series are listed below:

\section{Country-specific macro data:}

1. GDP per capita in local currency units. Indicator code: NY.GDP.PCAP.KN

2. Gross capital formation as \% of GDP. Indicator code: NE.GDI.TOTL.ZS

3. Imports of goods and services as \% of GDP. Indicator code: NE.IMP.GNFS.ZS

4. Exports of goods and services as \% of GDP. Indicator code: NE.EXP.GNFS.ZS

5. Household final consumption expenditure as \% of GDP. Indicator code: NE.CON.PETC.ZS

6. GDP per capita, PPP (constant 2005 international \$). Indicator code: NY.GDP.PCAP.PP.KD

7. Consumer Price Index $(2010=100)$. Indicator code: FP.CPI.TOTL

8. Official Exchange Rate (LCU per US\$, period average). Indicator code: PA.NUS.FCRF

The WDI database does not include CPI data for Argentina. We therefore sourced the CPI for Argentina from Cavallo and Bertolotti (2016).

The mean impulse responses reported in the paper are a weighted by the country's GDP. The GDP used for the weighting is the GDP, PPP (constant 2011 international \$), with indicator code NY.GDP.MKTP.PP.KD.

The criteria for a country to be included in the sample is similar to the one in SchmittGrohé and Uribe (2018). In particular, a country needs to have at least 30 consecutive annual observations and to belong to the group of poor and emerging countries. The group of poor and emerging countries is defined as all countries with average GDP per capita at PPP U.S. dollars of 2005 over the period 1980-2016 below 25000 dollars according to the WDI database.

A total of 41 countries satisfy this criteria: Algeria, Argentina, Bangladesh, Bolivia, Brazil, Burkina Faso, Cameroon, Chad, Colombia, Congo, Cote d'Ivore, Dominican Republic, Egypt, Equatorial Guinea, Gabon, Ghana, Guatemala, Honduras, India, Indonesia, Jordan, Kenya, Madagascar, Malawi, Malaysia, Mauritius, Mexico, Morocco, Niger, Nigeria, Pakistan, Panama, Peru, Philippines, Senegal, South Africa, Sudan, Thailand, Tunisia, Turkey and Uruguay. However, our final sample has 38 countries as we exclude Malaysia, Panama, and Tunisia. The reason for excluding these countries is that our constructed terms of trade measure does not mimic the terms of trade data from the WDI. Coincidentally, Schmitt-Grohé and Uribe (2018) highlight that Panama has faulty terms of trade data and therefore they exclude it from their sample. It is uncertain whether the same applies to the other two countries but we prefer to remain conservative and discard the countries for which our measure of terms of 
trade is not a good approximation of the official measure. Table A.1 reports the data coverage for each country.

\section{World data:}

Real world GDP at 2010 prices and 2010 exchange rates is sourced from Haver Analytics and includes the following economies: United States, Japan, Germany, France, United Kingdom, Italy, Canada, Spain, Netherlands, Australia, Switzerland, Belgium, Sweden, Austria, Denmark, Norway, Finland, Greece, Portugal, Ireland, New Zealand, Luxembourg, Argentina, Bolivia, Brazil, Chile, Colombia, Costa Rica, Ecuador, Mexico, Peru, Uruguay, Venezuela, Macao, India, Indonesia, Malaysia, Pakistan, People's Republic of China-Mainland, People's Republic of China-Hong Kong Special Administrative Region, Philippines, Singapore, South Korea, People's Republic of China-Taiwan Province, Thailand, Vietnam, Poland, Czech Republic, Hungary, Slovakia, Slovenia, Estonia, Lithuania, Latvia, Russia, Ukraine, Romania, Bulgaria, Croatia, Albania, Kazakhstan, Israel, Turkey and South Africa. Real world GDP is calculated by Haver Analytics based on data from national statistical offices starting in 2001 . Data from 1980 through 2000 are linked by Haver Analytics using the growth rates of the real world GDP series in the World Development Indicators (WDI) database. The indicator code for this series is A001GDPD@IMFWEO.

\section{A.2 Export and Import Price Indices}

As explained in the main text, we calculate country-specific export and import price indices denominated in US dollars using sectoral export and import shares, commodity prices, and sectoral U.S. PPI data as a proxy for manufacturing prices.

The weights for the calculation of export and import price indices are given by the products' trade shares. In order to calculate the trade shares, for each country, we obtain a time series of highly disaggregated product export and import values sourced from the MIT Observatory of Economic Complexity. ${ }^{1}$ This dataset combines data from the Center for International Data from Robert Feenstra and UN COMTRADE. The product trade data are disaggregated at the 4-digit level and classified according to the Standard International Trade Classification, Revision 2 (SITC Rev. 2). Our sample consists of 988 categories but since we only have price information for 62 categories, the trade shares have to be reclassified so that we can match trade and price data. We therefore match the trade shares associated with each of the 988 categories with 46 commodity and 16 industry classifications for which we have price information. The matched information is then used to recalculate export and import shares for a total of 62 categories. $^{2}$ The sources of price data are detailed in Tables A.2 and A.3. Note that the manufacturing industries are classified according to the North American Industry Classification System (NAICS) code. In order to match the sectoral manufacturing price data with the trade shares, NAICS codes were reclassified to match with the SITC classification.

Once we have the series of weights obtained from the trade shares and prices for each of the categories, we calculate, for each country, the export and import price indices.

\footnotetext{
${ }^{1}$ The data can be accessed at https://atlas.media.mit.edu/en/.

${ }^{2}$ The number of categories is dictated by the price data.
} 
Table A.1: Macro Data Coverage

\begin{tabular}{ll}
\hline \hline Country & Data \\
\hline Algeria & $1980-2016$ \\
Argentina & $1987-2016$ \\
Bangladesh & $1986-2016$ \\
Bolivia & $1980-2016$ \\
Brazil & $1980-2016$ \\
Burkina Faso & $1980-2016$ \\
Cameroon & $1980-2016$ \\
Chad & $1983-2015$ \\
Colombia & $1980-2016$ \\
Congo, Dem. Rep. & $1980-2013$ \\
Cote d'Ivoire & $1980-2016$ \\
Dominican Republic & $1980-2016$ \\
Egypt, Arab Rep. & $1980-2016$ \\
Equatorial Guinea & $1985-2016$ \\
Gabon & $1980-2016$ \\
Ghana & $1980-2013$ \\
Guatemala & $1980-2016$ \\
Honduras & $1980-2016$ \\
India & $1980-2016$ \\
Indonesia & $1980-2016$ \\
Jordan & $1980-2016$ \\
Kenya & $1980-2015$ \\
Madagascar & $1980-2016$ \\
Malawi & $1980-2016$ \\
Mauritius & $1980-2015$ \\
Mexico & $1980-2016$ \\
Morocco & $1980-2016$ \\
Niger & $1980-2015$ \\
Nigeria & $1981-2015$ \\
Pakistan & $1980-2016$ \\
Peru & $1980-2016$ \\
Philippines & $1980-2016$ \\
Southegal Africa & $1980-2016$ \\
Sudan & $1980-2016$ \\
Thailand & $1980-2015$ \\
\hline \hline & $1980-2016$ \\
Uruguay & $1980-2016$ \\
\hline
\end{tabular}

Notes: This table shows the data coverage for each of the countries included in our sample. 
Table A.2: List of commodities

\begin{tabular}{|c|c|c|}
\hline Commodity & Definition & Source \\
\hline Crude oil & Average between Brent, Dubai and WTI & World Bank Commodity Price Data \\
\hline Coal & Australian & World Bank Commodity Price Data \\
\hline Natural gas & Natural gas index (average of Europe, US and Japan) & World Bank Commodity Price Data \\
\hline Cocoa & International Cocoa Organization indicator & World Bank Commodity Price Data \\
\hline Coffee & Average between arabica and robusta & World Bank Commodity Price Data \\
\hline Tea & Average between Kolkata, Colombo and Mombasa & World Bank Commodity Price Data \\
\hline Coconut oil & Philippines/Indonesia, bulk, c.i.f. Rotterdam & World Bank Commodity Price Data \\
\hline Copra & Philippines/Indonesia, bulk, c.i.f. N.W. Europe & World Bank Commodity Price Data \\
\hline Palm oil & Malaysia, $5 \%$ bulk, c.i.f. N. W. Europe & World Bank Commodity Price Data \\
\hline Soybeans & US, c.i.f. Rotterdam & World Bank Commodity Price Data \\
\hline Soybean oil & Crude, f.o.b. ex-mill Netherlands & World Bank Commodity Price Data \\
\hline Soybean meal & Argentine $45 / 46 \%$ extraction, c.i.f. Rotterdam & World Bank Commodity Price Data \\
\hline Barley & US & World Bank Commodity Price Data \\
\hline Maize & US & World Bank Commodity Price Data \\
\hline Rice & $5 \%$ broken, white rice (WR), f.o.b. Bangkok & World Bank Commodity Price Data \\
\hline Wheat & US, no. 1 , hard red winter & World Bank Commodity Price Data \\
\hline Banana & US import price, f.o.t. US Gulf ports & World Bank Commodity Price Data \\
\hline Orange & navel, EU indicative import price, c.i.f. Paris & World Bank Commodity Price Data \\
\hline Beef & Australia/New Zealand, c.i.f. U.S. port (East Coast) & World Bank Commodity Price Data \\
\hline Chicken & Broiler/fryer, Georgia Dock, wholesale & World Bank Commodity Price Data \\
\hline Sheep & New Zealand, wholesale, Smithfield, London & World Bank Commodity Price Data \\
\hline Meat & Average of beef, chicken and sheep & World Bank Commodity Price Data \\
\hline Sugar & World, f.o.b. at greater Caribbean ports & World Bank Commodity Price Data \\
\hline Tobacco & General import, cif, US & World Bank Commodity Price Data \\
\hline Cotton & Index & World Bank Commodity Price Data \\
\hline Rubber & Any origin, spot, New York & World Bank Commodity Price Data \\
\hline Aluminum & London Metal Exchange & World Bank Commodity Price Data \\
\hline Iron ore & Spot in US dollar & World Bank Commodity Price Data \\
\hline Copper & London Metal Exchange & World Bank Commodity Price Data \\
\hline Lead & London Metal Exchange & World Bank Commodity Price Data \\
\hline Tin & London Metal Exchange & World Bank Commodity Price Data \\
\hline Nickel & London Metal Exchange & World Bank Commodity Price Data \\
\hline Zinc & London Metal Exchange & World Bank Commodity Price Data \\
\hline Gold & UK & World Bank Commodity Price Data \\
\hline Platinum & UK & World Bank Commodity Price Data \\
\hline Silver & UK & World Bank Commodity Price Data \\
\hline Beverages & Index, $2010=100$ & World Bank Commodity Price Data \\
\hline Food & Index, $2010=100$ & World Bank Commodity Price Data \\
\hline Oils and Meals & Index, $2010=100$ & World Bank Commodity Price Data \\
\hline Grains & Index, $2010=100$ & World Bank Commodity Price Data \\
\hline Timber & Index, $2010=100$ & World Bank Commodity Price Data \\
\hline Other Raw Mat. & Index, $2010=100$ & World Bank Commodity Price Data \\
\hline Fertilizers & Index, $2010=100$ & World Bank Commodity Price Data \\
\hline Metals and Minerals & Index, $2010=100$ & World Bank Commodity Price Data \\
\hline Base Metals & Index, $2010=100$ & World Bank Commodity Price Data \\
\hline Precious Metals & Index, $2010=100$ & World Bank Commodity Price Data \\
\hline
\end{tabular}

Notes: The first column of this table shows the list of all commodities used for the calculation of export and import prices, the second column displays the definition used for each commodity price, and the last column shows the the data source. 
Table A.3: List of Manufacturing Industries

\begin{tabular}{llll}
\hline \hline Industry & NAICS Code & Definition & Source \\
\hline MUV Index & & Index, nominal & World Bank \\
Processed Foods and Feeds & 311,312 & PPI Index & FRED \\
Textile products and apparel & $313,314,315$ & PPI Index & FRED \\
Hides, skins, leather, and related products & 316 & PPI Index & FRED \\
Chemicals and allied products & 325 & PPI Index & FRED \\
Rubber and plastic products & 326 & PPI Index & FRED \\
Lumber and wood products & 321 & PPI Index & FRED \\
Pulp, paper, and allied products & 322,323 & PPI Index & FRED \\
Metals and metal products & 331,332 & PPI Index & FRED \\
Machinery and equipment & 333 & PPI Index & FRED \\
Electronic components and accessories & 334 & PPI Index & FRED \\
Electrical equipment, appliances, and component manufacturing & 335 & PPI Index & FRED \\
Furniture and household durables & 337 & PPI Index & FRED \\
Nonmetallic mineral products & 327 & PPI Index & FRED \\
Transportation equipment & 336 & PPI Index & FRED \\
Miscellaneous products & 339 & FRED \\
\hline \hline
\end{tabular}

Notes: The first column of this table shows the list of manufacturing sectors used to calculate export and import prices, the second column describes the NAICS code associated with each manufacturing group, the third column displays the definition used for each
producer price index, and the last column shows the data source. Since all indices from the World Bank dataset have a base $2010=100$ and those from the Federal Reserve Bank of St. Louis FRED have a base of $1982=100$, we rebased the latter ones to $2010=100$. 


\section{A.3 Additional Results from Raw Data}

This section includes additional details about the data. Specifically, Table A.4. provides a detailed comparison of our proxy of ToT and the associated $P^{x}$ and $P^{m}$ against equivalent measures that cover only raw commodity prices. In particular, this table provides the country results behind Table 3 in the paper. Tables A.5-A.7 provide additional information about country specific export and import specialization (equivalent to Table 1 in the main draft) for three different subsamples of our data.

Table A.4: Commodity Terms of Trade: Descriptive Statistics

\begin{tabular}{|c|c|c|c|c|c|c|c|}
\hline & $\sigma\left(P_{c}^{x}\right) / \sigma\left(P^{x}\right)$ & $\gamma_{1}\left(P_{c}^{x}\right)$ & $\sigma\left(P_{c}^{m}\right) / \sigma\left(P^{m}\right)$ & $\gamma_{1}\left(P_{c}^{m}\right)$ & $\operatorname{Corr}\left(P_{c}^{x}, P_{c}^{m}\right)$ & $\sigma\left(T o T^{c}\right) / \sigma(T o T)$ & $\gamma_{1}\left(T o T^{c}\right)$ \\
\hline Algeria & 1.08 & 65.7 & 2.84 & 65.1 & 51.3 & 0.6 & 72.2 \\
\hline Argentina & 1.36 & 65.3 & 4.68 & 66.0 & 94.8 & 0.5 & 44.9 \\
\hline Bangladesh & 4.71 & 67.2 & 2.36 & 68.4 & 94.4 & 0.5 & 70.2 \\
\hline Bolivia & 1.07 & 67.2 & 3.41 & 62.5 & 88.8 & 0.5 & 58.7 \\
\hline Brazil & 1.68 & 68.5 & 2.87 & 66.3 & 91.0 & 1.5 & 62.4 \\
\hline Burkina Faso & 1.09 & 67.0 & 2.88 & 62.1 & 59.6 & 0.8 & 70.9 \\
\hline Cameroon & 1.10 & 65.7 & 2.52 & 60.0 & 89.2 & 0.4 & 60.4 \\
\hline Chad & 1.05 & 57.5 & 4.13 & 66.2 & 88.0 & 0.5 & 28.7 \\
\hline Colombia & 1.35 & 62.2 & 3.97 & 64.1 & 83.8 & 0.6 & 50.0 \\
\hline Congo, Dem. Rep. & 1.45 & 64.8 & 2.81 & 60.5 & 91.1 & 0.6 & 55.7 \\
\hline Cote d'Ivoire & 1.12 & 63.6 & 2.16 & 59.1 & 69.6 & 1.2 & 50.9 \\
\hline Dominican Republic & 1.91 & 62.2 & 2.95 & 63.2 & 81.0 & 0.7 & 40.2 \\
\hline Egypt, Arab Rep. & 1.51 & 62.7 & 2.14 & 64.8 & 70.1 & 0.9 & 69.7 \\
\hline Equatorial Guinea & 1.04 & 60.1 & 4.05 & 65.2 & 83.6 & 0.3 & 51.4 \\
\hline Gabon & 1.05 & 61.9 & 3.14 & 63.8 & 70.4 & 0.6 & 61.8 \\
\hline Ghana & 1.11 & 63.9 & 2.85 & 61.3 & 82.5 & 0.8 & 47.4 \\
\hline Guatemala & 1.70 & 69.9 & 2.96 & 64.8 & 70.6 & 1.0 & 57.5 \\
\hline Honduras & 2.13 & 72.6 & 2.59 & 66.2 & 71.1 & 0.6 & 61.0 \\
\hline India & 2.75 & 72.1 & 2.14 & 64.1 & 89.6 & 1.4 & 64.8 \\
\hline Indonesia & 1.61 & 69.2 & 2.38 & 64.6 & 95.0 & 0.5 & 75.7 \\
\hline Jordan & 1.95 & 60.0 & 2.44 & 67.5 & 93.7 & 1.3 & 20.0 \\
\hline Kenya & 1.29 & 66.4 & 2.81 & 65.8 & 71.7 & 1.2 & 57.7 \\
\hline Madagascar & 1.59 & 61.8 & 3.38 & 70.0 & 87.4 & 1.1 & 61.4 \\
\hline Malawi & 1.11 & 71.5 & 3.09 & 59.6 & 61.7 & 0.9 & 46.2 \\
\hline Mauritius & 1.89 & 64.3 & 3.05 & 63.4 & 72.4 & 1.4 & 58.6 \\
\hline Mexico & 3.14 & 64.7 & 4.62 & 65.4 & 91.5 & 0.8 & 55.5 \\
\hline Morocco & 2.10 & 66.0 & 2.70 & 64.1 & 94.3 & 0.9 & 50.7 \\
\hline Niger & 2.04 & 64.3 & 2.61 & 70.4 & 39.0 & 1.1 & 74.3 \\
\hline Nigeria & 1.06 & 62.9 & 3.14 & 67.7 & 74.4 & 0.5 & 65.9 \\
\hline Pakistan & 3.34 & 71.9 & 2.22 & 64.8 & 81.9 & 0.9 & 66.9 \\
\hline Peru & 1.19 & 73.1 & 2.73 & 64.3 & 93.7 & 0.4 & 39.7 \\
\hline Philippines & 3.43 & 66.2 & 4.02 & 64.1 & 89.4 & 1.0 & 44.7 \\
\hline Senegal & 1.28 & 63.8 & 2.14 & 62.0 & 94.3 & 0.8 & 53.5 \\
\hline South Africa & 1.71 & 72.8 & 3.77 & 63.0 & 94.3 & 0.7 & 53.0 \\
\hline Sudan & 1.02 & 66.4 & 3.44 & 60.0 & 89.0 & 0.3 & 25.8 \\
\hline Thailand & 2.61 & 70.7 & 2.97 & 64.0 & 87.3 & 1.0 & 52.6 \\
\hline Turkey & 2.87 & 69.5 & 3.20 & 68.6 & 94.4 & 0.6 & 67.7 \\
\hline Uruguay & 1.41 & 66.9 & 2.45 & 63.3 & 71.1 & 2.1 & 69.4 \\
\hline Median & 1.48 & 65.9 & 2.87 & 64.2 & 87.4 & 0.8 & 57.6 \\
\hline Share of PC \#1 & 76.6 & & 93.5 & & & 63.2 & \\
\hline
\end{tabular}

Notes: $\sigma$ denotes standard deviation; $\gamma_{1}$ is the first order autocorrelation; $C o r r$ denotes correlation; $P_{c}^{x}\left(P_{c}^{m}\right)$ and $P^{x}\left(P^{x}\right)$ are the commodity export (import) price and our export (import) price, respectively; $T o T^{c}$ is the commodity terms of trade measure while $T o T$ is the terms of trade measure calculated using our export and import price indices. All entries are in percentage terms and variables are calculated as the quadratically detrended logarithm of the original data to remove low frequency trends. Therefore, the standard deviations are the standard deviation of the percentage deviations of the series from the trends. 
Table A.5: Commodity Info: 1980 - 1989

\begin{tabular}{|c|c|c|c|c|c|c|c|c|c|c|c|c|c|c|}
\hline \multirow[b]{2}{*}{ Algeria } & \multirow{2}{*}{$\begin{array}{c}\text { Comm. Imp. \% } \\
29.7\end{array}$} & \multirow{2}{*}{$\begin{array}{c}\text { Comm. Exp. \% } \\
97.5\end{array}$} & \multicolumn{6}{|c|}{ Main Imports } & \multicolumn{6}{|c|}{ Main Exports } \\
\hline & & & Met. \& Min. & 6.5 & Food & 5.0 & Wheat & 4.8 & Crude oil & 76.7 & Natural gas & 19.8 & Beverages & 0.3 \\
\hline Argentina & 25.0 & 76.2 & Natural gas & 5.1 & Crude oil & 3.5 & Met. \& Min. & 2.4 & Food & 10.0 & Soybean meal & 7.2 & Soybeans & 7.0 \\
\hline Bangladesh & 42.5 & 36.2 & Wheat & 8.5 & Crude oil & 7.7 & Cotton & 5.9 & Other R. M. & 13.2 & Food & 11.9 & Tea & 4.8 \\
\hline Bolivia & 17.2 & 96.0 & Met. \& Min. & 6.2 & Wheat & 4.1 & Food & 2.6 & Natural gas & 39.4 & Tin & 25.6 & Gold & 6.4 \\
\hline Brazil & 46.5 & 59.3 & Crude oil & 21.1 & Wheat & 5.1 & Fertilizers & 3.3 & Coffee & 11.1 & Iron ore & 9.2 & Soybean meal & 6.9 \\
\hline Burkina Faso & 30.0 & 94.0 & Food & 8.4 & Met. \& Min. & 4.7 & Crude oil & 4.6 & Cotton & 35.0 & Oils \& Meals & 20.3 & Gold & 14.8 \\
\hline Cameroon & 22.7 & 96.8 & Met. \& Min. & 6.1 & Crude oil & 3.6 & Food & 3.5 & Crude oil & 49.3 & Cocoa & 14.5 & Coffee & 13.9 \\
\hline Chad & 21.6 & 93.4 & Food & 5.6 & Wheat & 2.7 & Rice & 2.1 & Cotton & 79.0 & Crude oil & 5.9 & Other R. M. & 5.1 \\
\hline Colombia & 23.7 & 82.6 & Crude oil & 8.1 & Met. \& Min. & 2.7 & Food & 2.3 & Coffee & 50.0 & Crude oil & 10.9 & Banana & 7.1 \\
\hline Congo, Dem. Rep. & 21.0 & 80.8 & Crude oil & 6.6 & Food & 4.1 & Met. \& Min. & 3.3 & Copper & 37.3 & Crude oil & 13.7 & Coffee & 12.4 \\
\hline Cote d'Ivoire & 35.2 & 93.7 & Crude oil & 11.4 & Food & 8.9 & Met. \& Min. & 4.5 & Cocoa & 31.5 & Coffee & 24.1 & Timber & 15.2 \\
\hline Dominican Republic & 27.3 & 61.0 & Food & 4.9 & Met. \& Min. & 3.9 & Fertilizers & 3.0 & Sugar & 21.3 & Coffee & 8.9 & Gold & 7.2 \\
\hline Egypt, Arab Rep. & 35.8 & 89.3 & Wheat & 6.5 & Food & 5.2 & Met. \& Min. & 3.7 & Crude oil & 72.8 & Cotton & 7.8 & Aluminum & 2.8 \\
\hline Equatorial Guinea & 36.5 & 94.7 & Fertilizers & 7.2 & Food & 6.3 & Beverages & 6.2 & Cocoa & 45.0 & Timber & 31.3 & Orange & 6.0 \\
\hline Gabon & 17.5 & 93.4 & Met. \& Min. & 6.8 & Food & 3.1 & Crude oil & 1.6 & Crude oil & 74.1 & Timber & 10.3 & Met. \& Min. & 7.1 \\
\hline Ghana & 28.4 & 94.7 & Crude oil & 6.1 & Aluminum & 5.5 & Food & 5.0 & Cocoa & 53.0 & Aluminum & 22.7 & Timber & 7.3 \\
\hline Guatemala & 29.8 & 82.3 & Crude oil & 8.4 & Met. \& Min. & 4.1 & Food & 3.9 & Coffee & 37.2 & Food & 10.6 & Cotton & 8.0 \\
\hline Honduras & 22.6 & 90.2 & Crude oil & 5.3 & Food & 4.8 & Met. \& Min. & 4.1 & Banana & 35.8 & Coffee & 22.3 & Food & 9.9 \\
\hline India & 34.1 & 44.6 & Crude oil & 9.4 & Fertilizers & 4.8 & Met. \& Min. & 2.2 & Food & 7.4 & Crude oil & 6.4 & Iron ore & 5.7 \\
\hline Indonesia & 33.5 & 91.0 & Crude oil & 15.8 & Met. \& Min. & 3.3 & Rice & 2.0 & Crude oil & 52.0 & Natural gas & 14.8 & Timber & 4.9 \\
\hline Jordan & 39.0 & 71.1 & Crude oil & 13.5 & Food & 5.8 & Met. \& Min. & 3.7 & Fertilizers & 44.5 & Food & 9.7 & Crude oil & 4.1 \\
\hline Malawi & 10.9 & 96.0 & Met. \& Min. & 3.7 & Food & 1.8 & Fertilizers & 0.9 & Tobacco & 57.2 & Tea & 19.3 & Sugar & 10.2 \\
\hline Malaysia & 31.3 & 71.0 & Crude oil & 11.5 & Food & 3.9 & Met. \& Min. & 2.9 & Crude oil & 19.0 & Timber & 15.0 & Rubber & 13.0 \\
\hline Mauritius & 23.9 & 58.9 & Food & 7.3 & Met. \& Min. & 3.2 & Other R. M. & 1.9 & Sugar & 52.5 & Food & 2.9 & Tea & 1.6 \\
\hline Mexico & 23.7 & 62.8 & Met. \& Min. & 3.5 & Maize & 2.3 & Other R. M. & 2.2 & Crude oil & 43.2 & Food & 5.7 & Coffee & 2.2 \\
\hline Morocco & 37.7 & 67.0 & Crude oil & 9.2 & Wheat & 4.5 & Fertilizers & 4.0 & Fertilizers & 27.4 & Food & 17.9 & Orange & 8.9 \\
\hline Niger & 22.8 & 14.3 & Met. \& Min. & 4.1 & Food & 3.8 & Crude oil & 3.5 & Met. \& Min. & 7.1 & Crude oil & 2.8 & Other R. M. & 1.0 \\
\hline Nigeria & 25.6 & 99.3 & Food & 6.2 & Crude oil & 6.0 & Met. \& Min. & 4.9 & Crude oil & 95.7 & Cocoa & 2.1 & Other R. M. & 0.3 \\
\hline Pakistan & 45.2 & 39.2 & Crude oil & 20.3 & Fertilizers & 3.8 & Tea & 3.0 & Cotton & 13.6 & Rice & 9.7 & Food & 4.7 \\
\hline Panama & 20.6 & 49.2 & Crude oil & 8.5 & Food & 3.0 & Met. \& Min. & 2.9 & Banana & 18.8 & Food & 12.7 & Crude oil & 5.5 \\
\hline Peru & 25.8 & 88.7 & Met. \& Min. & 3.6 & Wheat & 3.6 & Food & 2.8 & Crude oil & 18.4 & Copper & 17.7 & Zinc & 10.0 \\
\hline Philippines & 32.0 & 54.4 & Crude oil & 13.9 & Food & 2.9 & Met. \& Min. & 2.3 & Coconut oil & 8.0 & Food & 7.6 & Copper & 7.0 \\
\hline Senegal & 36.3 & 92.4 & Food & 8.0 & Crude oil & 6.1 & Rice & 5.1 & Food & 35.7 & Oils \& Meals & 18.5 & Fertilizers & 17.4 \\
\hline South Africa & 12.5 & 65.6 & Met. \& Min. & 3.5 & Other R. M. & 1.5 & Food & 1.2 & Coal & 10.4 & Gold & 9.1 & Platinum & 8.9 \\
\hline Sudan & 33.0 & 96.0 & Crude oil & 7.3 & Wheat & 5.9 & Food & 4.2 & Cotton & 35.3 & Other R. M. & 16.3 & Grains & 8.8 \\
\hline Thailand & 30.3 & 66.2 & Crude oil & 11.3 & Food & 2.9 & Met. \& Min. & 2.8 & Food & 22.9 & Rice & 11.8 & Rubber & 7.4 \\
\hline Tunisia & 33.2 & 56.9 & Crude oil & 11.4 & Met. \& Min. & 3.5 & Wheat & 2.9 & Crude oil & 32.0 & Fertilizers & 10.1 & Food & 9.7 \\
\hline Turkey & 37.2 & 59.0 & Crude oil & 21.5 & Fertilizers & 2.3 & Iron ore & 1.9 & Food & 14.6 & Grains & 7.7 & Crude oil & 7.7 \\
\hline Uruguay & 31.9 & 61.4 & Crude oil & 12.7 & Other R. M. & 2.6 & Fertilizers & 2.6 & Gold & 15.9 & Beef & 12.6 & Other R. M. & 9.9 \\
\hline Median & 29.7 & 82.3 & & 7.3 & & 3.9 & & 3.0 & & 35.3 & & 11.9 & & 7.1 \\
\hline
\end{tabular}


Table A.6: Commodity Info: 1990 - 1999

\begin{tabular}{|c|c|c|c|c|c|c|c|c|c|c|c|c|c|c|}
\hline \multirow[b]{2}{*}{ Algeria } & \multirow{2}{*}{$\begin{array}{c}\text { Comm. Imp. \% } \\
36.9\end{array}$} & \multirow{2}{*}{$\begin{array}{c}\text { Comm. Exp. \% } \\
85.6\end{array}$} & \multicolumn{6}{|c|}{ Main Imports } & \multicolumn{6}{|c|}{ Main Exports } \\
\hline & & & Food & 8.4 & Wheat & 8.0 & Met. \& Min. & 3.2 & Crude oil & 60.6 & Natural gas & 23.9 & Fertilizers & 0.3 \\
\hline Argentina & 18.1 & 69.7 & Met. \& Min. & 2.7 & Food & 2.1 & Crude oil & 2.0 & Food & 11.8 & Soybean meal & 9.0 & Crude oil & 8.4 \\
\hline Bangladesh & 31.9 & 15.6 & Wheat & 5.0 & Crude oil & 4.9 & Food & 3.8 & Food & 9.3 & Other R. M. & 2.8 & Fertilizers & 1.2 \\
\hline Bolivia & 22.6 & 91.2 & Wheat & 4.8 & Met. \& Min. & 3.7 & Food & 3.3 & Natural gas & 17.4 & Tin & 11.4 & Gold & 8.8 \\
\hline Brazil & 30.6 & 49.3 & Crude oil & 7.9 & Food & 3.9 & Coal & 2.5 & Iron ore & 7.9 & Coffee & 4.9 & Soybean meal & 4.9 \\
\hline Burkina Faso & 27.8 & 92.2 & Food & 6.9 & Crude oil & 5.2 & Met. \& Min. & 3.5 & Cotton & 55.5 & Gold & 16.7 & Food & 7.4 \\
\hline Cameroon & 28.8 & 96.4 & Met. \& Min. & 4.7 & Food & 4.6 & Crude oil & 4.0 & Crude oil & 40.0 & Timber & 21.0 & Cocoa & 8.6 \\
\hline Chad & 25.6 & 95.3 & Wheat & 5.5 & Food & 3.9 & Met. \& Min. & 3.8 & Cotton & 83.0 & Other R. M. & 11.1 & Oils \& Meals & 0.6 \\
\hline Colombia & 21.4 & 72.8 & Crude oil & 3.8 & Food & 2.6 & Met. \& Min. & 2.3 & Coffee & 22.1 & Crude oil & 21.8 & Banana & 7.2 \\
\hline Congo, Dem. Rep. & 26.3 & 53.9 & Food & 5.4 & Wheat & 4.4 & Met. \& Min. & 2.8 & Copper & 16.2 & Met. \& Min. & 12.3 & Crude oil & 10.4 \\
\hline Cote d'Ivoire & 30.6 & 90.0 & Food & 9.6 & Crude oil & 6.2 & Met. \& Min. & 3.3 & Cocoa & 38.9 & Timber & 11.0 & Coffee & 10.8 \\
\hline Dominican Republic & 26.2 & 24.6 & Crude oil & 7.6 & Food & 4.0 & Met. \& Min. & 2.6 & Sugar & 4.7 & Tobacco & 4.0 & Precious & 3.6 \\
\hline Egypt, Arab Rep. & 38.1 & 70.0 & Wheat & 9.2 & Food & 4.0 & Timber & 3.5 & Crude oil & 52.9 & Food & 4.8 & Cotton & 3.0 \\
\hline Equatorial Guinea & 43.1 & 94.1 & Beverages & 9.2 & Met. \& Min. & 7.5 & Food & 6.5 & Timber & 54.3 & Crude oil & 23.5 & Cocoa & 10.5 \\
\hline Gabon & 22.6 & 97.0 & Food & 5.5 & Met. \& Min. & 4.6 & Beef & 1.8 & Crude oil & 73.3 & Timber & 14.7 & Met. \& Min. & 8.0 \\
\hline Ghana & 24.3 & 80.2 & Met. \& Min. & 4.5 & Crude oil & 4.0 & Food & 3.4 & Cocoa & 33.9 & Aluminum & 17.4 & Timber & 11.5 \\
\hline Guatemala & 29.9 & 59.5 & Crude oil & 9.9 & Food & 4.4 & Met. \& Min. & 3.0 & Coffee & 20.7 & Food & 10.0 & Sugar & 8.2 \\
\hline Honduras & 29.8 & 57.2 & Crude oil & 10.2 & Food & 5.7 & Met. \& Min. & 3.0 & Banana & 17.1 & Food & 15.9 & Coffee & 14.2 \\
\hline India & 36.1 & 30.2 & Crude oil & 12.3 & Fertilizers & 3.7 & Gold & 2.8 & Food & 5.1 & Met. \& Min. & 3.7 & Iron ore & 2.8 \\
\hline Indonesia & 28.8 & 54.7 & Crude oil & 8.7 & Met. \& Min. & 2.8 & Other R. M. & 2.5 & Crude oil 16.1 & Natural gas & 10.7 & Food & 5.6 & \\
\hline Jordan & 34.0 & 71.1 & Food & 5.8 & Sugar & 3.8 & Wheat & 3.6 & Fertilizers & 55.4 & Food & 5.1 & Sheep & 3.3 \\
\hline Kenya & 24.0 & 80.6 & Crude oil & 4.3 & Met. \& Min. & 2.9 & Sugar & 2.2 & Tea & 25.9 & Coffee & 19.2 & Food & 17.6 \\
\hline Madagascar & 22.1 & 74.9 & Food & 4.7 & Met. \& Min. & 3.7 & Crude oil & 2.3 & Food & 42.8 & Coffee & 13.4 & Met. \& Min. & 4.6 \\
\hline Malawi & 22.1 & 90.8 & Fertilizers & 5.3 & Met. \& Min. & 4.4 & Maize & 2.7 & Tobacco & 67.2 & Tea & 9.4 & Sugar & 5.5 \\
\hline Mauritius & 25.4 & 34.0 & Food & 6.3 & Crude oil & 4.0 & Met. \& Min. & 2.7 & Sugar & 26.3 & Food & 3.3 & Precious & 1.6 \\
\hline Mexico & 20.6 & 28.0 & Met. \& Min. & 4.5 & Food & 2.6 & Crude oil & 2.1 & Crude oil & 14.0 & Food & 4.3 & Met. \& Min. & 2.5 \\
\hline Morocco & 38.9 & 46.1 & Crude oil & 11.0 & Wheat & 3.9 & Fertilizers & 3.0 & Food & 19.4 & Fertilizers & 13.0 & Orange & 5.3 \\
\hline Niger & 29.5 & 20.3 & Food & 6.2 & Sugar & 3.6 & Met. \& Min. & 3.5 & Crude oil & 15.6 & Cotton & 0.9 & Food & 0.8 \\
\hline Nigeria & 20.0 & 98.3 & Food & 4.3 & Met. \& Min. & 4.0 & Crude oil & 2.8 & Crude oil & 93.8 & Cocoa & 1.7 & Rubber & 0.8 \\
\hline Pakistan & 42.7 & 18.9 & Crude oil & 12.7 & Wheat & 5.3 & Palm oil & 5.2 & Cotton & 6.8 & Food & 2.9 & Rice & 2.6 \\
\hline Peru & 32.9 & 82.0 & Crude oil & 8.1 & Wheat & 4.0 & Food & 3.6 & Copper & 20.6 & Zinc & 12.6 & Food & 8.6 \\
\hline Philippines & 27.9 & 27.5 & Crude oil & 10.5 & Food & 2.8 & Met. \& Min. & 1.7 & Food & 6.8 & Copper & 3.4 & Coconut oil & 3.2 \\
\hline Senegal & 40.0 & 86.6 & Food & 8.1 & Crude oil & 5.9 & Rice & 5.7 & Food & 44.6 & Oils \& Meals & 14.2 & Fertilizers & 11.2 \\
\hline South Africa & 15.4 & 64.7 & Met. \& Min. & 2.9 & Crude oil & 2.3 & Food & 1.3 & Gold & 13.6 & Platinum & 9.2 & Coal & 8.6 \\
\hline Sudan & 29.5 & 95.8 & Wheat & 8.1 & Food & 6.3 & Met. \& Min. & 3.2 & Cotton & 29.1 & Grains & 17.9 & Other R. M. & 17.4 \\
\hline Thailand & 25.2 & 34.2 & Crude oil & 8.6 & Met. \& Min. & 3.3 & Food & 2.7 & Food & 14.4 & Rice & 4.4 & Rubber & 3.6 \\
\hline Turkey & 33.3 & 30.6 & Crude oil & 11.2 & Iron ore & 3.0 & Other R. M. & 2.6 & Food 10.3 & Met. \& Min. & 3.5 & Tobacco & 2.8 & \\
\hline Uruguay & 26.6 & 51.7 & Crude oil & 8.2 & Food & 2.9 & Met. \& Min. & 2.4 & Beef & 11.8 & Food & 11.5 & Rice & 6.8 \\
\hline Median & 26.6 & 69.7 & & 6.2 & & 4.0 & & 2.8 & & 20.6 & & 10.3 & & 5.5 \\
\hline
\end{tabular}


Table A.7: Commodity Info: 2000 - 2016

\begin{tabular}{|c|c|c|c|c|c|c|c|c|c|c|c|c|c|c|}
\hline \multirow[b]{2}{*}{ Algeria } & \multirow{2}{*}{$\begin{array}{c}\text { Comm. Imp. \% } \\
28.4\end{array}$} & \multirow{2}{*}{$\begin{array}{c}\text { Comm. Exp. \% } \\
92.2\end{array}$} & \multicolumn{6}{|c|}{ Main Imports } & \multicolumn{6}{|c|}{ Main Exports } \\
\hline & & & Food & 6.3 & Wheat & 5.6 & Met. \& Min. & 3.5 & Crude oil & 59.3 & Natural gas & 31.8 & Fertilizers & 0.3 \\
\hline Argentina & 16.1 & 68.9 & Met. \& Min. & 2.5 & Natural gas & 2.4 & Crude oil & 1.7 & Soybean meal & 12.4 & Food & 9.8 & Crude oil & 9.2 \\
\hline Bangladesh & 36.6 & 7.3 & Crude oil & 5.6 & Cotton & 4.8 & Palm oil & 4.1 & Food & 4.4 & Other R. M. & 1.1 & Fertilizers & 0.4 \\
\hline Bolivia & 22.0 & 91.7 & Crude oil & 5.9 & Food & 3.4 & Met. \& Min. & 3.3 & Natural gas & 35.9 & Soybean meal & 9.3 & Zinc & 6.8 \\
\hline Brazil & 29.5 & 56.5 & Crude oil & 11.2 & Fertilizers & 3.5 & Food & 2.2 & Iron ore & 10.7 & Crude oil & 6.6 & Soybeans & 6.2 \\
\hline Burkina Faso & 29.3 & 89.9 & Crude oil & 5.5 & Food & 5.1 & Met. \& Min. & 3.1 & Cotton & 49.1 & Gold & 23.4 & Grains & 6.7 \\
\hline Cameroon & 38.5 & 92.0 & Crude oil & 14.3 & Food & 5.4 & Met. \& Min. & 3.3 & Crude oil & 43.8 & Timber & 16.2 & Cocoa & 10.9 \\
\hline Chad & 18.6 & 95.8 & Met. \& Min. & 5.1 & Food & 3.5 & Wheat & 3.5 & Crude oil & 65.8 & Cotton & 23.3 & Other R. M. & 5.4 \\
\hline Colombia & 18.8 & 69.9 & Food & 3.0 & Met. \& Min. & 2.1 & Crude oil & 2.0 & Crude oil & 32.1 & Coal & 13.2 & Coffee & 6.4 \\
\hline Congo, Dem. Rep. & 35.4 & 66.0 & Food & 7.1 & Met. \& Min. & 5.3 & Crude oil & 5.0 & Met. \& Min. & 25.4 & Copper & 21.1 & Crude oil & 12.5 \\
\hline Cote d'Ivoire & 48.3 & 86.9 & Crude oil & 22.2 & Rice & 7.5 & Food & 6.5 & Cocoa & 41.8 & Crude oil & 13.1 & Food & 6.1 \\
\hline Dominican Republic & 32.3 & 30.1 & Crude oil & 9.9 & Food & 4.8 & Met. \& Min. & 2.6 & Tobacco & 5.8 & Gold & 4.3 & Precious & 3.6 \\
\hline Egypt, Arab Rep. & 41.8 & 55.4 & Wheat & 5.4 & Crude oil & 5.3 & Food & 4.1 & Crude oil & 22.2 & Natural gas & 7.7 & Food & 7.7 \\
\hline Equatorial Guinea & 20.9 & 96.2 & Met. \& Min. & 7.9 & Beverages & 4.0 & Food & 2.6 & Crude oil & 82.8 & Natural gas & 9.4 & Timber & 3.0 \\
\hline Gabon & 26.8 & 96.1 & Food & 5.4 & Met. \& Min. & 5.0 & Crude oil & 2.7 & Crude oil & 73.2 & Timber & 12.0 & Met. \& Min. & 9.8 \\
\hline Ghana & 30.4 & 89.6 & Crude oil & 8.9 & Food & 4.7 & Met. \& Min. & 3.7 & Cocoa & 37.0 & Gold & 13.4 & Crude oil & 9.0 \\
\hline Guatemala & 30.2 & 54.3 & Crude oil & 9.7 & Food & 5.0 & Met. \& Min. & 2.7 & Food & 12.1 & Coffee & 9.5 & Sugar & 7.6 \\
\hline Honduras & 31.4 & 42.7 & Crude oil & 9.9 & Food & 6.5 & Met. \& Min. & 2.5 & Coffee & 12.9 & Food & 10.8 & Banana & 3.9 \\
\hline India & 49.0 & 29.5 & Crude oil & 19.7 & Gold & 9.0 & Coal & 3.1 & Crude oil & 4.9 & Food & 3.5 & Precious & 3.3 \\
\hline Indonesia & 38.5 & 53.7 & Crude oil & 18.4 & Food & 2.6 & Met. \& Min. & 2.3 & Crude oil & 9.5 & Natural gas & 8.2 & Coal & 7.7 \\
\hline Jordan & 36.8 & 45.3 & Crude oil & 11.5 & Food & 4.8 & Met. \& Min. & 2.1 & Fertilizers & 25.6 & Food & 7.7 & Met. \& Min. & 2.7 \\
\hline Kenya & 34.7 & 71.4 & Crude oil & 15.8 & Palm oil & 3.1 & Met. \& Min. & 2.3 & Tea & 19.6 & Food & 16.1 & Other R. M. & 14.6 \\
\hline Madagascar & 24.8 & 52.6 & Met. \& Min. & 4.9 & Food & 4.7 & Rice & 2.8 & Food & 33.5 & Met. \& Min. & 4.8 & Nickel & 4.6 \\
\hline Malawi & 29.7 & 87.5 & Fertilizers & 6.1 & Crude oil & 4.5 & Tobacco & 3.7 & Tobacco & 56.2 & Sugar & 8.4 & Tea & 7.7 \\
\hline Malaysia & 22.7 & 26.3 & Crude oil & 6.0 & Food & 2.3 & Met. \& Min. & 1.9 & Crude oil & 6.8 & Natural gas & 5.2 & Palm oil & 4.8 \\
\hline Mauritius & 33.4 & 35.9 & Food & 9.8 & Crude oil & 6.8 & Met. \& Min. & 2.9 & Sugar & 15.4 & Food & 13.0 & Precious & 2.4 \\
\hline Mexico & 17.7 & 23.6 & Met. \& Min. & 4.1 & Crude oil & 2.6 & Food & 2.0 & Crude oil & 12.2 & Food & 3.3 & Met. \& Min. & 2.5 \\
\hline Morocco & 35.3 & 41.1 & Crude oil & 11.1 & Natural gas & 3.6 & Wheat & 3.1 & Food & 16.7 & Fertilizers & 11.5 & Crude oil & 3.0 \\
\hline Niger & 32.4 & 43.4 & Food & 6.9 & Tobacco & 3.9 & Palm oil & 3.0 & Crude oil & 18.9 & Met. \& Min. & 15.3 & Food & 2.3 \\
\hline Nigeria & 26.5 & 95.5 & Food & 6.3 & Wheat & 3.7 & Met. \& Min. & 3.6 & Crude oil & 85.4 & Natural gas & 6.2 & Cocoa & 1.2 \\
\hline Pakistan & 42.7 & 21.9 & Crude oil & 18.6 & Palm oil & 4.2 & Food & 2.2 & Rice & 6.9 & Food & 3.6 & Crude oil & 2.0 \\
\hline Panama & 12.7 & 43.7 & Crude oil & 3.7 & Food & 2.4 & Met. \& Min. & 2.1 & Food & 12.8 & Banana & 9.7 & Crude oil & 5.9 \\
\hline Peru & 32.2 & 81.3 & Crude oil & 13.0 & Met. \& Min. & 2.8 & Food & 2.6 & Copper & 21.4 & Gold & 15.9 & Food & 9.5 \\
\hline Philippines & 27.1 & 15.4 & Crude oil & 11.4 & Food & 3.0 & Wheat & 1.3 & Food & 3.1 & Copper & 1.7 & Banana & 1.7 \\
\hline Senegal & 46.6 & 65.9 & Crude oil & 16.0 & Rice & 6.7 & Food & 6.1 & Food & 32.0 & Crude oil & 6.9 & Oils \& Meals & 5.6 \\
\hline South Africa & 28.1 & 53.0 & Crude oil & 15.8 & Met. \& Min. & 2.1 & Food & 1.5 & Platinum & 10.3 & Gold & 7.6 & Coal & 6.5 \\
\hline Sudan & 22.0 & 97.9 & Met. \& Min. & 4.4 & Food & 4.4 & Wheat & 3.6 & Crude oil & 61.8 & Gold & 17.9 & Grains & 5.2 \\
\hline Thailand & 33.8 & 25.7 & Crude oil & 14.6 & Met. \& Min. & 3.5 & Gold & 2.7 & Food & 7.5 & Rubber & 3.3 & Crude oil & 2.6 \\
\hline Turkey & 28.0 & 21.7 & Crude oil & 7.4 & Iron ore & 3.3 & Gold & 2.7 & Food 6.2 & Met. \& Min. & 4.5 & Crude oil & 2.0 & \\
\hline Tunisia & 27.1 & 27.8 & Crude oil & 7.9 & Natural gas & 2.9 & Met. \& Min. & 2.7 & Crude oil & 11.1 & Food & 7.2 & Fertilizers & 4.8 \\
\hline Uruguay & 34.6 & 65.0 & Crude oil & 16.0 & Food & 3.9 & Fertilizers & 2.6 & Beef & 16.3 & Food & 13.0 & Soybeans & 7.5 \\
\hline Median & 30.2 & 56.5 & & 7.9 & & 4.2 & & 2.7 & & 19.6 & & 9.5 & & 5.4 \\
\hline
\end{tabular}




\section{Appendix B Narrative Approach}

This appendix documents the construction of a narrative series of exogenous price shocks for the commodities analyzed. We examined historical documents to identify episodes of large commodity price changes that were unrelated to the state of the economy (i.e. were not demand driven). We then classified this episode as a negative or positive price shock, depending on the direction of the price change. This will ultimately translate into a negative or positive export or import price shock, for each country, depending on whether the country is an exporter or importer of that commodity.

The series were constructed by using a number of sources: Food and Agriculture Organization (FAO) reports, publications from the International Monetary Fund (IMF) and the World Bank (WB), newspaper articles, academic papers and a number of online sources. In order to establish some rules at the time of selecting the dates, we followed the criteria listed below.

1. The event has to be important enough to affect a commodity market at a global level. Examples of these are natural disasters or weather related shocks in key areas where the commodity is produced, major geopolitical events, and unanticipated news on the volume of global production or demand of commodities.

2. The event should have an unambiguous effect on the price of the commodity.

3. The event has to be unrelated to important macroeconomic developments such as the global financial crisis or a US recession. This aims at eliminating endogenous responses of commodity prices to the state of the economy.

By using this criteria we were able to identify 23 episodes of exogenous commodity price shocks that are unrelated to business cycle fluctuations. Of these events, 17 are favorable commodity price shocks and 6 are negative price shocks. In what follows we document the dates selected, organizing the commodities in the following subgroups: (1) Agriculture: Food and Beverage Commodities, (2) Agriculture: Raw Materials, (3) Fertilizers, (4) Metals and Mineral Commodities. At the end of this section, we document some country-specific assumptions.

\section{B.1 Agriculture: Food and Beverage Commodities}

\section{i. Coffee}

Year of Event: 1986.

Type of Event: Positive price shock.

A report from the International Coffee Organization (ICO) states that in 1986 Arabicas were in short supply following a drought in Brazil which triggered a large price increase. ${ }^{3}$ In fact, our data show that between 1985 and 1986 Arabica coffee prices increased from 3.23 dollars per kilo to 4.29 dollars per kilo.

According to the IMF Primary Commodities Report from May 1987, "a prolonged period of dry weather in 1985 in the major coffee producing states of Parana, São Paulo, and Minas Gerais seriously disrupted and greatly reduced the flowering of coffee trees, which normally occurs between mid-September and early November. The rains that occurred in early November and in early December were insufficient to reverse the damage caused ot the 1986 crop. The 1986 crop in Brazil (April 1986-March 1987) was about 11 million 60-kilogram bags compared

\footnotetext{
${ }^{3}$ Report available at: http://www.ico.org/news/icc-111-5-r1e-world-coffee-outlook.pdf.
} 
with the 26-28 million bag harvest which might have been expected with normal weather on an off-year in the two-year Brazilian production cycle." The same report highlights that coffee prices in 1986 averaged two thirds above those in the third quarter of 1985 .

Newspaper Articles. A number of newspaper articles document the severity of the drought and the consequences on prices. An example is listed below.

Drought Damages Brazilian Coffee, The Washington Post (January 29, 1986):

"A six-month drought has destroyed more than half of Brazil's coffee crop, leaving many local farmers devastated while promising large financial gains for speculators with coffee beans to hoard, as the cost of a cup of coffee rises around the world."

Year of Event: 1994.

Type of Event: Positive price shock.

According to a report from the International Coffee Organization (ICO), climate shocks which affected coffee prices were recorded in Brazil in 1994. ${ }^{5}$ Our data are in line with this observation given that we observe that Arabica coffee prices increased from 1.56 dollars per kilo in 1993 to 3.31 in 1994.

Newspaper Articles. A newspaper article from the New York Times documents that the climate shock of 1994 in Brazil is related to a frost. Some important aspects of the article are quoted in what follows.

New Frost Hits Brazilian Coffee, New York Times (July 11, 1994): ${ }^{6}$

"Frost struck in Brazil's biggest coffee-growing state early today, and farmers said the effects were harsher than a freeze that hit two weeks ago."

"(...)Coffee prices soared after the previous cold snap late last month, which destroyed onethird of next year's crop. Brazil is the largest coffee producer, accounting for about a quarter of world production. A threat to its crop can drastically affect world coffee prices(...)."

\section{ii. Cereal ${ }^{7}$}

Year of Event: 1985.

Type of Event: Negative price shock.

De Winne and Peersman (2016) document that favorable weather in North America and exceptionally good cereal harvest in Western Europe in the fourth quarter of 1984 led to a decline in cereal prices. A report from the FAO indicates that "In developed countries food and agricultural production has gone up between 5\% and 5.5\%. Much of this increase is a consequence of the North American recovery from the sharp decline of 1983, reflecting both increased plantings and favorable weather. Western Europe also had exceptionally good harvests of cereals, and some progress was made in the USSR and Eastern Europe." 8 Our

\footnotetext{
${ }^{4}$ Article available at: https://www.washingtonpost.com/archive/politics/1986/01/29/droughtdamages-brazilian-coffee/94a07436-4f78-4f46-b4e7-d3924b13a2e3/?utm_term=.4fd4b80da637.

${ }^{5}$ Report available at: http://www.ico.org/news/icc-111-5-r1e-world-coffee-outlook.pdf.

${ }^{6}$ Article available at: https://www.nytimes.com/1994/07/11/business/new-frost-hits-brazil-coffee. html.

${ }^{7}$ In our sample, we use cereal as a proxy for the category "food" as we observe that many countries are net food importers and evidence suggests that cereals are by far the most important source of food consumption. This fact is documented by the FAO and further information can be found at http://www.fao.org/docrep/ 006/Y4683E/y4683e06.htm.

${ }^{8}$ Available at: http://www.fao.org/docrep/017/ap664e/ap664e.pdf.
} 
data reveal a decline in grain prices from 1984 to 1985, when the index went from 63.27 to 53.54 .

Year of Event: 1988.

Type of Event: Positive price shock.

As it will be explained below, in 1988 we observe positive price shocks for wheat, corn and soybean, therefore implying a positive price shock for cereal.

Year of Event: 1997.

Type of Event: Negative price shock.

As documented in De Winne and Peersman (2016), in 1996 the FAO issued a favorable forecast for world 1996 cereal output. ${ }^{9}$ The largest increase was expected in coarse grains output, mostly in developed countries. Overall, global cereal production increased by 7.8 percent that year and this translated into lower prices. Our data show that the cereal price index experienced a sharp reduction from 1996 to 1997, going from 83.61 to 64.76 .

Year of Event: 2010.

Type of Event: Positive price shock.

De Winne and Peersman (2016) report that cereal output was seriously affected by adverse weather conditions in key producing countries in Europe. A group of countries that includes the Russian Federation, Kazakhstan and Ukraine suffered from a heatwave and droughts while the Republic of Moldova had floods. According to a report from the FAO, "International prices of grain have surged since the beginning of July in response to drought-reduced crops in CIS exporting countries and a subsequent decision by the Russian Federation to ban exports." 10

\section{iii. Cocoa}

Year of Event: 2002.

Type of Event: Positive price shock.

According to a report from the International Cocoa Organization, the increase in cocoa prices in 2002 was largely due to an attempted coup on 19th September in Cote d'Ivore, which is the leading cocoa producing country. Uncertainty over potential disruptions emanating from the sociopolitical crisis and civil war pushed prices to a 16-year high at 2.44 dollars per tonne in October 2002. ${ }^{11}$ Our data show that between 2001 and 2002 cocoa prices increased from 1.07 dollars per kilo to 1.78 dollars per kilo.

Newspaper Articles. A newspaper article from the New York Times documents the cocoa price increase originated in Cote d'Ivore in 2002. Some important aspects of the article are quoted below.

War Inflates Cocoa Prices But Leaves Africans Poor, New York Times (October 31, 2002): ${ }^{12}$

"As civil war raged in Ivory Coast, the world's biggest cocoa producer, speculative traders here and in New York sent prices this month to 17-year highs."

\section{iv. Corn}

\footnotetext{
${ }^{9}$ The FAO document is available at: http://www.fao.org/docrep/004/w1690e/w1690e02.htm\#I2.

${ }^{10}$ Available at: http://www.fao.org/docrep/012/ak354e/ak354e00.pdf.

${ }^{11}$ https://www.icco.org/about-us/international-cocoa-agreements/cat_view/30-relateddocuments/45-statistics-other-statistics.html.

${ }^{12}$ Article available at: https://www.nytimes.com/2002/10/31/business/war-inflates-cocoa-pricesbut-leaves-africans-poor.html.
} 
Year of Event: 1988.

Type of Event: Positive price shock.

The severe drought that affected the Farm Belt had a significant impact on corn prices in the 1988/1989 crop years. According to Karrenbrock (1989) corn yields were the most affected by the drought. ${ }^{13}$ Our data feature a clear increase in corn prices from 1987 to 1988 . In particular, prices went from 75.70 per tonne in 1987 to 106.89 per tonne in 1988 .

Newspaper Articles. A newspaper article from the Los Angeles Times and another article from the New York Times document the severity of the drought and the impact on corn prices. Some important aspects of the articles are quoted below.

Commodities: Grain Prices Skyrocket in Response to Drought Report, Los Angeles Times (July $14,1988):{ }^{14}$

"Grain and soybean futures prices blasted out of their recent slump Wednesday in response to the government's report of severe drought damage to crops and forecasts for more hot, dry weather in the Farm Belt."

"Besides slashing its 1988 corn production estimate by $29 \%$ to a five-year low of 5.2 billion bushels, the USDA estimated soybean plantings this year at 58.52 million acres, a figure below the market's expectations, analysts said."

“(...) corn was 10 cents to 27.5 cents higher, with July at $\$ 3.335$ a bushel; oats were 10 cents to 25.5 cents higher, with July at $\$ 3.045$ a bushel, and soybeans were 30 cents to 69 cents higher, with July at $\$ 9.485$ a bushel."

Drought Cutting U.S. Grain Crop 31\% This Year, Los Angeles Times (August 12, 1988): ${ }^{15}$

"The Agriculture Department estimated that this nation's corn harvest might total no more than 4.47 billion bushels, down 2.6 billion bushels from last year."

"Analysts predicted that prices of corn and soybeans would rise sharply Friday."

\section{v. Wheat}

Year of Event: 1988.

Type of Event: Positive price shock.

A report from the FAO highlights some facts that are useful to understand the positive price shock in $1988 .{ }^{16}$ Relevant aspects of the report are quoted below:

"World production of wheat fell again in 1988 to an estimated 511 million tons, slightly less than in the previous year but considerably below the last peak of 538 million tons in 1986 . This decline was mainly the result of smaller crops in North America, where the wheat area decreased further and the principal growing areas suffered from the worst drought in half a century. But there were declines in wheat production in Central and South America as well $(\ldots) "$

\footnotetext{
${ }^{13}$ https://research.stlouisfed.org/publications/review/1989/05/01/the-1988-drought-itsimpact-on-district-agriculture/.

${ }^{14}$ Article available at: http://articles.latimes.com/1988-07-14/business/fi-8706_1_grain-prices.

${ }^{15}$ Article available at: https://www.nytimes.com/1988/08/12/business/drought-cutting-us-graincrop-31-this-year.html.

${ }^{16}$ Commodity Review and Outlook 1988-89, Food and Agriculture Organization of the United Nations, page 53.
} 
Our data indicate that wheat prices went from 112.90 dollars per metric ton in 1987 to 145.20 dollars per metric ton in 1988.

\section{vi. Soybeans}

Year of Event: 1988.

Type of Event: Positive price shock.

The World Bank "Price Prospects for Major Primary Commodities, 1988-2000" documents that in 1988 there were droughts in the USA which severely affected soybean production. ${ }^{17}$ In order to put the severity of the drought into perspective, it is important to mention that the report explains that in 1980 the United States produced 65 percent of the world's soybeans, and prices were close to a historical high at $\$ 296$ per tonne. Therefore, it is not surprising to conclude that such a severe drought in a key area of production had the capacity to significantly affect total production and prices. Our data depict a sharp increase in soybean prices in 1988, going from 215.75 per tonne in 1987 to 303.50 in 1988.

Newspaper Articles. A newspaper article from Los Angeles Times supports the analysis. The key point is detailed below.

Commodities: Grain Prices Skyrocket in Response to Drought Report, Los Angeles Times (July $14,1988):{ }^{18}$

"Grain and soybean futures prices blasted out of their recent slump Wednesday in response to the government's report of severe drought damage to crops and forecasts for more hot, dry weather in the Farm Belt."

\section{vii. Sugar}

Year of Event: 1984.

Type of Event: Negative price shock.

According to a FAO report, sugar prices declined in 1984 to their lowest level in 13 years, reflecting a situation of oversupply. ${ }^{19}$ Our data show that prices declined by 40 percent in 1984. Interestingly, in 1984 Pepsico Inc. and Coca-Cola Company decided to stop using sugar in favor or a corn based sweetener for their drinks, which was associated with a fall in current and future consumption of sugar.

Newspaper Articles. Some articles are informative to illustrate the importance of the change in sweetener for the two giants of the soft-drink industry for the sugar market. We include an example below.

Coke, Pepsi to use more con syrup, New York Times (November 7, 1984): ${ }^{20}$

"For the sugar industry, the announcements mark the end of its involvement with soft drinks $(\ldots) "$

\footnotetext{
${ }^{17}$ http://documents . worldbank. org/curated/en/443751468739336774/Summary-energy-matals-andminerals.

${ }^{18}$ Article available at: http://articles.latimes.com/1988-07-14/business/fi-8706_1_grain-prices.

${ }^{19}$ http://www.fao.org/3/a-ap664e.pdf.

${ }^{20}$ Article available at: https://www.nytimes.com/1984/11/07/business/coke-pepsi-to-use-more-cornsyrup.html.
} 


\section{B.2 Agriculture: Raw Materials}

\section{i. Cotton}

Year of Event: 1994.

Type of Event: Positive price shock.

A report from the U.S. International Trade Commission describes that the 1994 cotton price increase was driven by a decline in production in key production areas such as China, and India. ${ }^{21}$ The decline in production in China is explained by bad weather and a bollworm infestation.

A study from the National Cotton Council of America explains that the price increase is also partly due to a recovery in world cotton consumption following the stagnation that resulted from the dissolution of the Soviet Union in the early 1990s. ${ }^{22}$

Our data indicate that cotton prices declined from 1.28 dollars per kilo in 1993 to 1.76 dollars per kilo in 1994.

Year of Event: 2003.

Type of Event: Positive price shock.

MacDonald and Meyer (2018) analyze the challenges faced when forecasting cotton prices in the long run. The article highlights that in 2003 there was a severe weather damage to cotton crops in China which resulted in a surge in cotton prices. In addition, an article from the National Cotton Council of America highlights that in the 2003 season, '(...) USDA's forecast put world sticks at their lowest level since 1994/95, raising the specter of a world cotton shortage for the first time in nearly a decade." ${ }^{23}$

Our data show that cotton prices increased from 1.02 dollars per kilo in 2002 to 1.40 dollars per kilo in 2003.

Year of Event: 2010.

Type of Event: Positive price shock.

Janzen, Smith and Carter (2018) analyze the extent to which cotton price movements can be attributed to comovement with other commodities vis-à-vis cotton specific developments. They point at the fact that in 2010-2011 cotton was scarce as a consequence of a negative supply shock generated by lower than average planted crops and negative weather shocks in the USA and Pakistan. This led to an increase in the price of cotton. The authors explain that this boom-bust appears to be cotton-specific, unlike other cases in which a set of macroeconomic factors drive the price of a broad range of commodities.

Our data confirm the findings of the paper. In fact, cotton prices increased from 1.38 dollars per kilo in 2009 to 2.28 dollars per kilo in 2010.

\section{ii. Timber}

\footnotetext{
${ }^{21}$ Article available at: https://books.google.com/books?id=0ZFDf6qLEosC\&pg=SA3-PA5\&lpg=SA3PA5\&dq=cotton+prices+1994\&source=bl\&ots=vi6JuOeGer\&sig=DX9iSSIDP__dPIGTNKEfB03FkSA\&hl=en\&sa=X\& ved=2ahUKEwi JkOOWztneAhVkneAKHWFOCWs4ChDoATADegQIBRAB\#v=onepage\&q=cotton $\backslash \% 20$ prices $\backslash \% 201994 \& f=$ false.

${ }^{22}$ Article available at: https://www.cotton.org/issues/2005/upload/WorldCottonMarket.pdf.

${ }^{23}$ Article available at: https://www.cotton.org/issues/2005/upload/WorldCottonMarket.pdf.
} 
Year of Event: 1993.

Type of Event: Positive price shock. Sohngen and Haynes (1994) explain that the 1993 price spike was driven by the environmentally friendly policies that President Clinton issued to protect forests which limited the timber harvests. ${ }^{24}$ The application of such policies is confirmed in the list of environmental actions taken by President Clinton and Vice President $\mathrm{Al}$ Gore and is documented in the White House Archives. ${ }^{25}$ Our data reveal that the timber price index increased from 72.41 in 1992 to 100.58 in 1993.

Newspaper Articles. A newspaper article from the Washington Post documents this episode and describes how the environmental policy was viewed as a threat to the woods product industry.

Clinton to Slash Logging (July 2, 1993): ${ }^{26}$.

"To protect the region's wildlife and old-growth forests, the administration plan will allow for average timber harvests over the next decade of 1.2 billion board feet per year. That is about half the level of the last two years, and only a third of the average rate between 1980 and 1992, when annual harvests swelled as high as 5.2 billion board feet."

\section{iii. Tobacco}

Year of Event: 1989.

Type of Event: Positive price shock.

In a report from the FAO, it is explained that in 1989 tobacco prices in Malawi remained buoyant due to a worldwide shortage of this type of tobacco. ${ }^{27}$ Our data show a 31 percent increase in the price of tobacco between 1988 and 1989.

Year of Event: 1993.

Type of Event: Negative price shock.

A report from the FAO highlights that the worldwide increase in competition for exports in 1993 led to a substantial fall in tobacco prices. ${ }^{28}$ Our data reveal that tobacco prices declined 22 percent between 1992 and 1993.

\section{B.3 Energy Commodities}

\section{i. Crude Oil}

Year of Event: 1986.

Type of Event: Negative price shock.

The period of oil price decline which finalized in a large drop in 1986 is referred to in Hamilton (2013) as "the great price collapse." In particular, in 1986 Saudi Arabia abandoned the effort

\footnotetext{
${ }^{24}$ Article available at: https://www.fs.fed.us/pnw/pubs/pnw_rp476.pdf.

${ }^{25}$ Available here https://clintonwhitehouse4.archives.gov/CEQ/earthday/ch13.html.

${ }^{26}$ https://www.washingtonpost.com/archive/politics/1993/07/02/clinton-to-slash-logging/f2266e63-f45f4f88-bd1f-5f1a1edd820f/

${ }^{27}$ Commodity Review and Outlook 1993-1994, Food and Agriculture Organization of the United Nations, page 135. Available at https://books.google.co.uk/books?id=xwNp0dp0siEC\&pg=PA154\&lpg= PA154\&dq=world+commodity+tobacco+prices+1993\&source=bl\&ots=Hm48B0nax6\&sig=frnhLU3FFikaxD1dNgq_GfC6Uc\&hl=en\&sa=X\&ved=2ahUKEwip09mhu6TeAhVM2qQKHU4CBM84ChDoATAGegQIAhAB\#v=onepage\&q=world $\backslash$ $\% 20$ commodity $\backslash \% 20$ tobacco $\% 20$ prices $\backslash \% 201993 \& f=$ false.

${ }^{28}$ Commodity Review and Outlook 1993-1994, Food and Agriculture Organization of the United Nations, page 156 .
} 
to keep oil prices high by reducing oil production which originated a very large oil supply shock. With Saudi Arabia increasing oil production, the price of oil declined from $\$ 27$ a barrel in 1985 to $\$ 12$ a barrel in 1986 .

Year of Event: 1990.

Type of Event: Positive price shock.

As explained in Hamilton (2013), this is the period marked by the first Persian Gulf War. Oil production in Iraq collapsed when the country invaded Kuwait in August 1990. The reduction in oil production together with the uncertainty that the conflict may spill over into Saudi Arabia led to the oil price almost doubling within a few months.

\section{ii. Natural Gas}

Year of Event: 2000.

Type of Event: Positive price shock.

The Energy Information Administration (EIA) documents the California energy crisis of 2000$2001 .^{29}$ In terms of natural gas, a report from the Task Force on Natural Gas Market Stability finds that "the 2000-2001 California natural gas crisis resulted in major part from a perfect storm of sudden demand increase, impaired physical capacity, natural gas diversion, and inadequate storage fill. The quick summary is as follows: Low hydroelectric availability in 2000, coupled with a modest increase in overall power needs resulted in a substantial increase in gas-fired generation usage, with little preparation." 30 A study from the Federal Reserve Bank of San Franciso documents the natural gas price increase in $2000 .{ }^{31}$ Our data show that the natural gas price index jumped from 39.78 in 1999 to 73.85 in 2000.

Year of Event: 2005.

Type of Event: Positive price shock.

An article from the "Oil and Gas Journal" highlights that the effects of Hurricanes Katrina and Rita were the main source of the price increase. Some details of the article are quoted below. ${ }^{32}$

"The combined effects of the 2004 and 2005 hurricane seasons had an impact across all sectors of the US gas industry. Hurricane Ivan, which made landfall in September 2004, caused more long-term gas production interruptions than any previous hurricane, but its impacts were dwarfed by Hurricanes Katrina (landfall Aug. 29, 2005) and Rita (Sept. 24, 2005). The combined effects of Hurricanes Katrina and Rita were by far the most damaging in the history of the US petroleum industry."

A report from the Federal Energy Regulatory Commission highlights the following: ${ }^{33}$

"The pump was primed for significant energy price effects well before Hurricanes Katrina and Rita hit the Gulf Coast production areas in September. The Gulf storms exacerbated already tight supply and demand conditions, increasing prices for fuels in the United States further after steady upward pressure on prices throughout the summer of 2005. Most of this was

\footnotetext{
${ }^{29}$ https://www.eia.gov/electricity/policies/legislation/california/subsequentevents.html

${ }^{30} \mathrm{http}$ ///bipartisanpolicy.org/wp-content/uploads/sites/default/files/Introduction $\backslash \% 20$ to $\backslash$ $\% 20$ North $\backslash \% 20$ American $\ \% 20$ Natural $\backslash \% 20$ Gas $\backslash \% 20$ Markets_0.pdf.

${ }^{31}$ https://www .frbsf .org/economic-research/publications/economic-letter/2001/february/ economic-impact-of-rising-natural-gas-prices/\#subhead3.

${ }^{32} \mathrm{https}$ ://www.ogj .com/articles/print/volume-104/issue-36/general-interest/us-gas-marketresponds-to-hurricane-disruptions.html.

${ }^{33}$ https : //www.ferc.gov/EventCalendar/Files/20051020121515-Gaspricereport.pdf.
} 
due to increased electric generation demand for natural gas caused by years of investment in gas-fired generation and a significantly warmer-than-average summer. Supply showed some weakness despite increasing numbers of active drilling rigs. The result was broadly higher energy prices."

Our natural gas index data shows a clear spike in 2005, going up from 95.39 in 2004 to 142.40 in 2005 .

Newspaper Articles. The increase in natural gas prices in the aftermath of the hurricanes received media attention. An example from NBC News is included in what follows. ${ }^{34}$

"Gas prices in cities across the United States soared by as much as 40 cents a gallon from Tuesday to Wednesday, a surge blamed on disruptions by Hurricane Katrina in Gulf of Mexico oil production."

\section{B.4 Fertilizers}

Year of Event: 1984.

Type of Event: Positive price shock.

According to a report from the FAO, the demand for fertilizers rebounded in 1984, leading to a price increase. ${ }^{35}$ This observation is supported by the "Proceedings of the 34th Annual Meeting of the Fertilizer Industry Round Table 1984." 36 Our data reveal a considerable increase in fertilizer prices in 1984. Specifically, the index went from 29.47 in 1983 to 36.62 in 1984 .

\section{B.5 Metals and Mineral Commodities}

\section{i. Copper}

Year of Event: 1981.

Type of Event: Negative price shock.

A report from the US Department of the Interior titled "Metal Prices in the United States through 1998" highlights that in 1981 copper prices were low due to a large growth in US and world production combined with rising inventories. Our data feature this price decline. In fact, our data show that copper prices went down from 1774.91 per tonne in 1980 to 1262.73 in 1981.

\section{ii. Iron ore}

Year of Event: 1982.

Type of Event: Positive price shock

According to "Metal Prices in the United States through 1998" iron ore production in the U.S. fell from 73.4 million tons in 1981 to 36.0 million tons in 1982. This decline in production was accompanied by a price increase, which we observe in our data. In fact, prices went up from 28.09 per dry metric ton in 1981 to 32.50 per dry metric ton in 1982.

\footnotetext{
${ }^{34} \mathrm{http}$ ://www.nbcnews.com/id/9146363/ns/business-local_business/t/pump-prices-jump-across-usafter-katrina/\#.W3NQbehKiUk.

${ }^{35}$ http://www.fao.org/3/a-ap664e.pdf.

${ }^{36}$ http://www.firt.org/sites/default/files/pdf/FIRT1984.pdf.
} 


\section{B.6 Country-Specific Assumptions}

In order to implement the narrative restrictions, a number of adjustments were necessary. In what follows we list the country-specific assumptions and clarify some events characteristics.

- The rule for associating a particular event to an export or import price shock is given by whether the country is an exporter or importer of that commodity. Following this rule, there are two cases in which the narrative restrictions translate into a positive export price shock originated in one commodity and a negative export price shock stemming from another commodity for the same year. Specifically, for Cameroon and Congo in 1986 we have a combination of a positive export price shock originated from coffee and a negative export price shock originated from crude oil. In this case, we attributed the sign of the export price shock according to the commodity that represents the larger weight in the export share. Since oil exports for both Cameroon and Congo represent a higher share than coffee exports in that year, the oil price shock dominates the coffee price shock, and therefore the coffee price shock is eliminated from the narrative.

- When an event is due to weather conditions or political events of a specific country, we exclude such event for that country. These cases are:

- The coffee price shock in 1986 which was caused by droughts in Brazil. We therefore did not use this shock as part of the narrative restrictions for Brazil.

- The cocoa price shock of 2002 was driven by an attempted coup in Cote d'Ivoire. Given that the country was suffering the consequences of a civil war with rising tensions we did not use the 2002 date for the narrative restrictions in this country.

- Some countries are exporters and importers of certain commodities in the same year. When this happens an event would serve both as an export price and import price shock. In our sample these happens for two events involving three countries:

- The negative oil price shock in 1986 implies a negative export price shock and a negative import price shock for Indonesia and Nigeria.

- The positive oil price shock in 1990 serves as a positive export price shock and a positive import price shock for Turkey. 


\section{Appendix C Empirical Evidence on Global Economic Activity Shocks}

Figure C.1: Impulse Responses to a Global Economic Activity Shock: All Countries
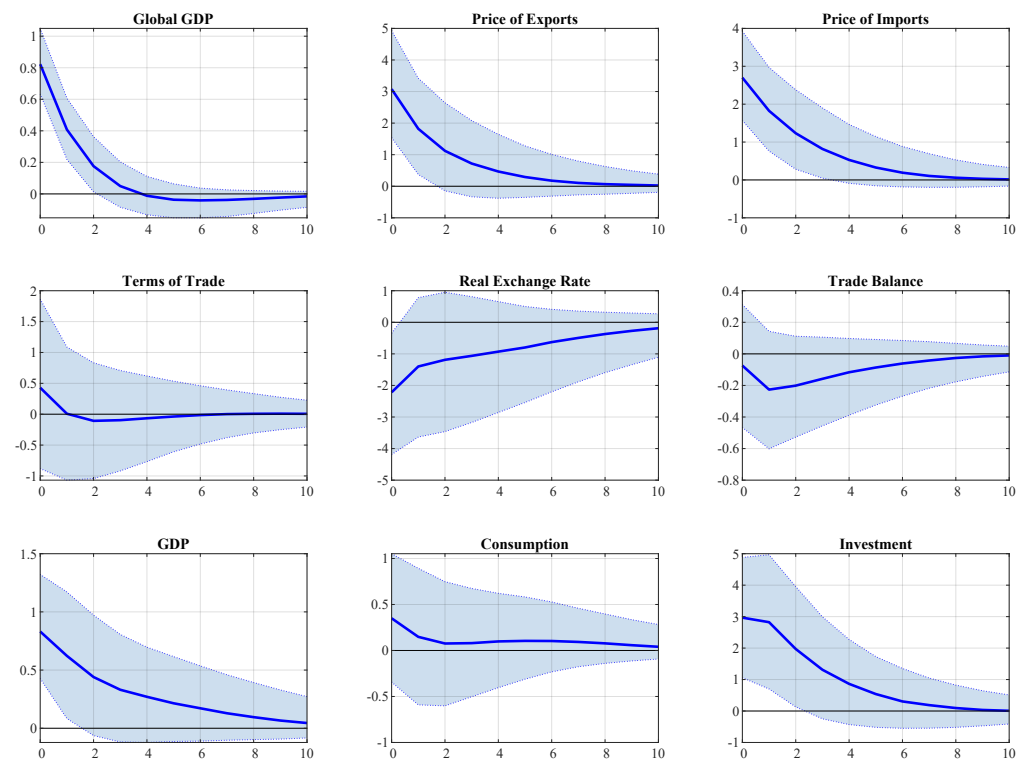

Notes: The figure shows the impulse responses to a one standard deviation shock in $Y^{g}$ for all countries using a VAR with sign and narrative restrictions. The blue solid lines denote the mean response weighted by each country's size proxied by their GDP (PPP) and the dashed lines represent the $16^{\text {th }}$ and $84^{\text {th }}$ percentile error bands.

Table C.1: Forecast Error Variance Decomposition: Global Economic Activity Shock

\begin{tabular}{ccccc}
\hline \hline & Export Prices & Import Prices & Terms of Trade & Real Exchange Rate \\
\cline { 2 - 5 } 0 & 33.08 & 40.98 & 23.11 & 12.21 \\
1 & 32.37 & 40.97 & 24.37 & 15.21 \\
4 & 32.08 & 40.27 & 25.88 & 18.79 \\
10 & 31.79 & 39.30 & 25.83 & 19.93 \\
\hline \hline \multirow{4}{*}{0} & Trade Balance & Output & Consumption & Investment \\
\cline { 2 - 5 } 1 & 10.65 & 17.99 & 8.60 & 15.72 \\
4 & 16.18 & 20.52 & 11.26 & 22.06 \\
10 & 20.39 & 23.35 & 14.19 & 25.55 \\
\hline \hline
\end{tabular}

Notes: The table shows the forecast error variance decomposition of all the variables in the VAR for $Y^{g}$ shocks on impact, at a 1-year, 2-year, 4-year and 10-year horizons. Reported are mean values weighted by each country's size proxied by their GDP (PPP). 


\section{Appendix D Cross-Country and Group Heterogeneity}

\section{D.1 Cross-Country Heterogeneity}

Figure D.1 depicts the impact impulse response (blue square) of export prices, import prices and output to a one standard deviation shock in $Y^{g}$. We observe that the effects on export prices are higher than on import prices. Interestingly, the countries with the largest increase in export prices following a $Y^{g}$ shock do not coincide with those showing the largest increase in import prices. The impact on output is heterogeneous across countries but large.

Figure D.1: Heterogeneous Effects of $Y^{g}$ Shocks on Export Prices, Import Prices and Output
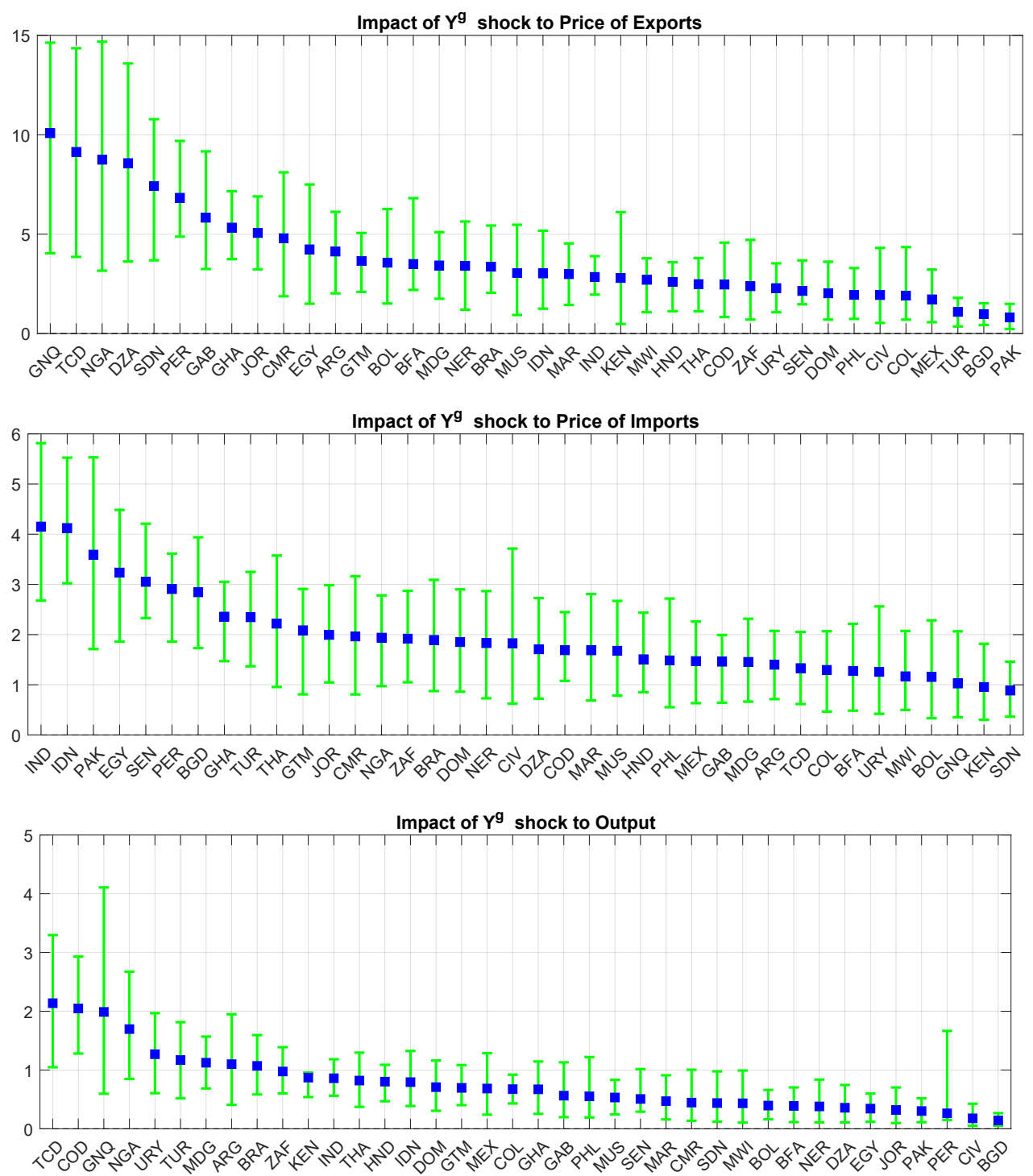

Notes: The figure shows the impact impulse response (blue square) on export prices, import prices and output (in \%) for each country in the sample to a one standard deviation shock in $Y^{g}$. The green lines represent 16th and 84 th percentile error bands.

Table D.1 shows the estimates of the determinants of the impact impulse responses of export prices, import prices, the terms of trade, output and the trade balance to a $Y^{g}$ shock for the 
Table D.1: Determinants of the Impulse Responses to a Global Economic Activity Shock

\begin{tabular}{lccccc}
\hline \hline & IRF $P^{x}$ & IRF $P^{m}$ & IRF ToT & IRF $Y$ & IRF TB \\
\cline { 2 - 6 } GDP Per Capita (PPP) & $0.566^{* *}$ & 0.059 & 0.462 & 0.058 & -0.096 \\
& $(0.218)$ & $(0.035)$ & $(0.663)$ & $(0.039)$ & $(0.089)$ \\
Commodity Export Share & $0.046^{* * *}$ & -0.004 & $0.059^{* * *}$ & -0.002 & 0.001 \\
& $(0.009)$ & $(0.003)$ & $(0.007)$ & $(0.001)$ & $(0.003)$ \\
Commodity Import Share & $0.064^{* *}$ & $0.033^{* * *}$ & -0.019 & $-0.016^{* *}$ & -0.005 \\
& $(0.030)$ & $(0.006)$ & $(0.176)$ & $(0.007)$ & $(0.010)$ \\
\hline \hline
\end{tabular}

Notes: The commodity export and import shares are the same as the ones reported in Table 1 of the main text. In all columns the total number of observations is 38 and the regression is robust to outliers. ${ }^{*}, * *$, and $* * *$ denote significance at the $10 \%, 5 \%$ and $1 \%$ levels, respectively.

cross-section of countries. ${ }^{37}$ Since in this case we are looking at the impact of one shock we use as regressors the GDP per capita (PPP), the commodity export share and the commodity import share. ${ }^{38}$ We find that countries which have a higher commodity export share exhibit, on average, a larger response of export prices and the terms of trade after a $Y^{g}$ shock. By contrast, the results suggest that countries which have a higher commodity import share display a larger response of import prices and export prices after a $Y^{g}$ shock.

\section{D.2 Analysis by Export and Import Group}

We analyze the effects of $P^{x}, P^{m}$, and $Y^{g}$ shocks by grouping the countries according to whether they are exporters or importers of main commodity groups. For exporters, we split the countries into agriculture (food and beverages), energy, manufacturing, metal and minerals (including precious metals) and agriculture raw materials (plus fertilizers). ${ }^{39}$ A country is classified as an exporter for a given commodity if more than 25 percent of its commodity export share is within a particular commodity class. A country falls into the manufacturing exporter category if less than 30 percent of its exports are commodities. ${ }^{40}$ For importers, we divide the countries into agriculture (food and beverages), energy, and manufacturing importers. A country is included in the category of importer of a given commodity if more than 15 percent of its commodity import share is within a particular commodity class. A country is classified as a manufacturing importer if less than 30 percent of its imports are commodities. The difference in the threshold for the classification of exporters and importers

\footnotetext{
${ }^{37}$ As before, the impact impulse response is defined as a 1 standard deviation shock in $Y^{g}$ multiplied by 100 and we perform robust to outliers regressions.

${ }^{38} \mathrm{We}$ also run separate specifications in which we have export and import characteristics in separate regressions as in Table 9 of the main text and the results remain robust. We do not include them here to preserve space but are available upon request.

${ }^{39}$ We bundled precious metals into the metal category as otherwise we would have no countries in the precious metal exporters category. This happens because precious metal exports do not represent a large enough share of exports. Therefore, we can think of this group as related to mining activity and including both industrial and precious metals. In addition, we included fertilizers into the agriculture raw materials group because otherwise we were left with a very small group on its own.

${ }^{40}$ The following countries are agriculture (food and beverages) exporters: Argentina, Brazil, Colombia, Cote d'Ivoire, Ghana, Guatemala, Honduras, Kenya, Madagascar, Malawi, Mauritius, Senegal, Sudan, Thailand, and Uruguay. Energy exporters are Algeria, Bolivia, Cameroon, Chad, Colombia, Egypt, Equatorial Guinea, Gabon, Indonesia, Nigeria, and Sudan. The following countries are metal exporters: Bolivia, Congo, Peru, and South Africa. Manufacturing exporters are Bangladesh, Niger, Pakistan and Philippines. Finally, agriculture raw materials (plus fertilizers) exporters are Burkina Faso, Chad, Equatorial Guinea, Jordan, Malawi, and Sudan.
} 
in each commodity group reflects the lower average share of commodities in imports and exports. $^{41}$

The impulse responses for each export group are summarized in Figures D.2, D.3, D.4 while for each import group they are included in Figures D.5, D.6, D.7. Each color denotes a sector: agriculture (food and beverages) is in green, energy in magenta, manufacturing in red, metals in blue, agriculture raw materials (plus fertilizers) in turquoise, and for comparison purposes the results for all countries are in black (with the corresponding dashed confidence bounds). In all cases shocks have been normalized to a 1 percent increase in $P^{x}, P^{m}$, and $Y^{g}$, respectively. The solid lines denote the mean response weighted by the country's size proxied by their GDP. The squares denote that zero is not within the 68 percent confidence band.

Figure D.2: Impulse Responses to an Export Price Shock by Export Group
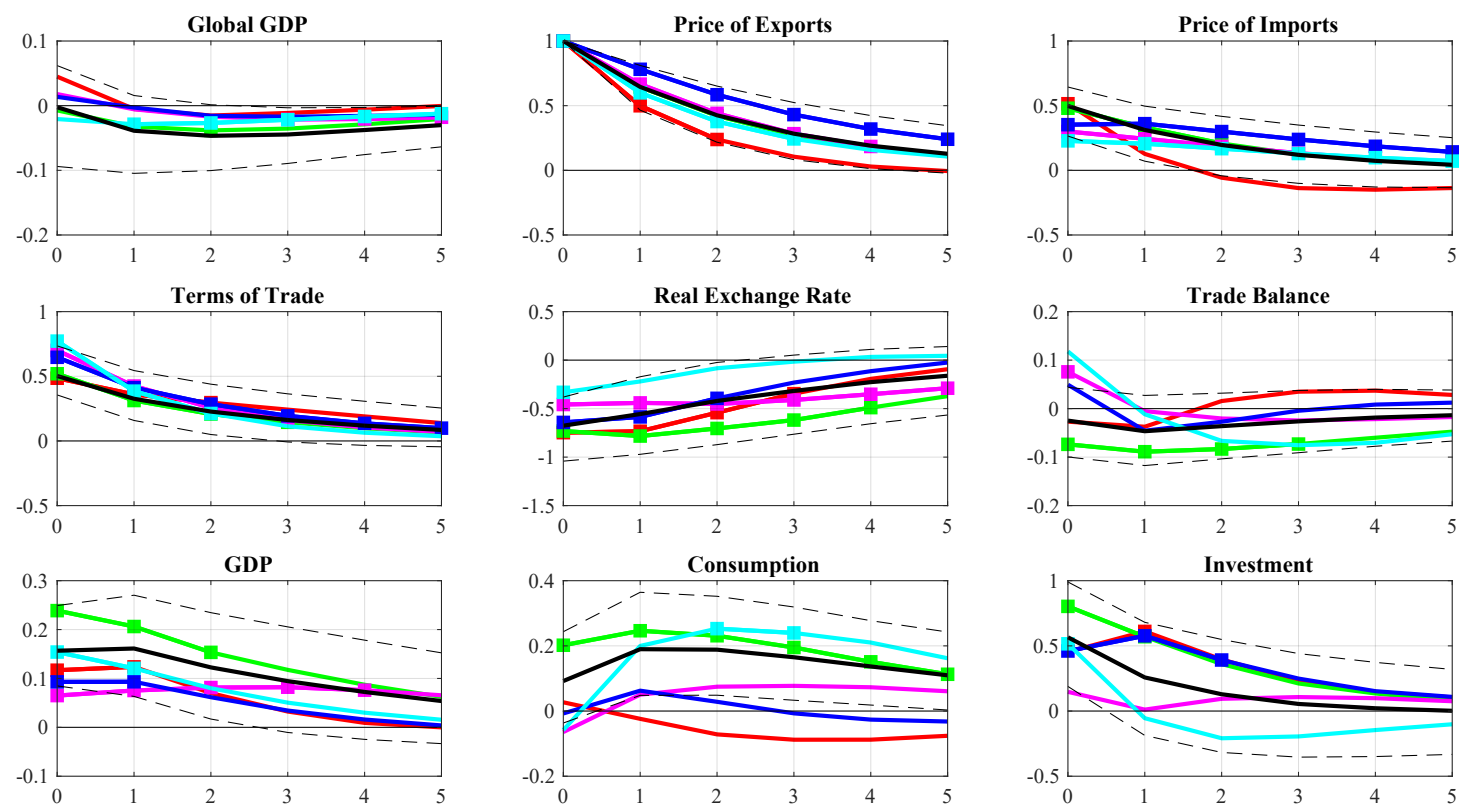

Notes: The figure shows the impulse responses to an export price shock for countries in each commodity group using a VAR with sign and narrative restrictions. Each color represents a different export group: agriculture (food and beverages) exporters are in green, energy exporters in magenta, manufacturing exporters in red, metal exporters in blue and agriculture raw material (plus fertilizers) exporters in turquoise. The lines denote the mean response weighted by each country's size proxied by their GDP (PPP). The squares denote that zero is not within the 68 percent confidence band. For comparison, the impulse responses for all countries are shown in black with the corresponding 16 th and 84 th percentile error bands.

\footnotetext{
${ }^{41}$ The country split is as follows. Manufacturing importers is composed of Argentina, Bolivia, Burkina Faso, Chad, Colombia, Congo, Dominican Republic, Gabon, Ghana, Honduras, Madagascar, Malawi, Mauritius, Mexico, Niger, Nigeria, Philippines, South Africa and Sudan. The group of agriculture (food and beverages) importers includes Algeria, Bangladesh, Burkina Faso, Congo, Cote d'Ivoire, Egypt, Equatorial Guinea, Jordan, Madagascar, Mauritius, Niger, Senegal and Sudan. Energy importers are Brazil, Cote d' Ivoire, India, Indonesia, and Pakistan.
} 
Figure D.3: Impulse Responses to an Import Price Shock by Export Group
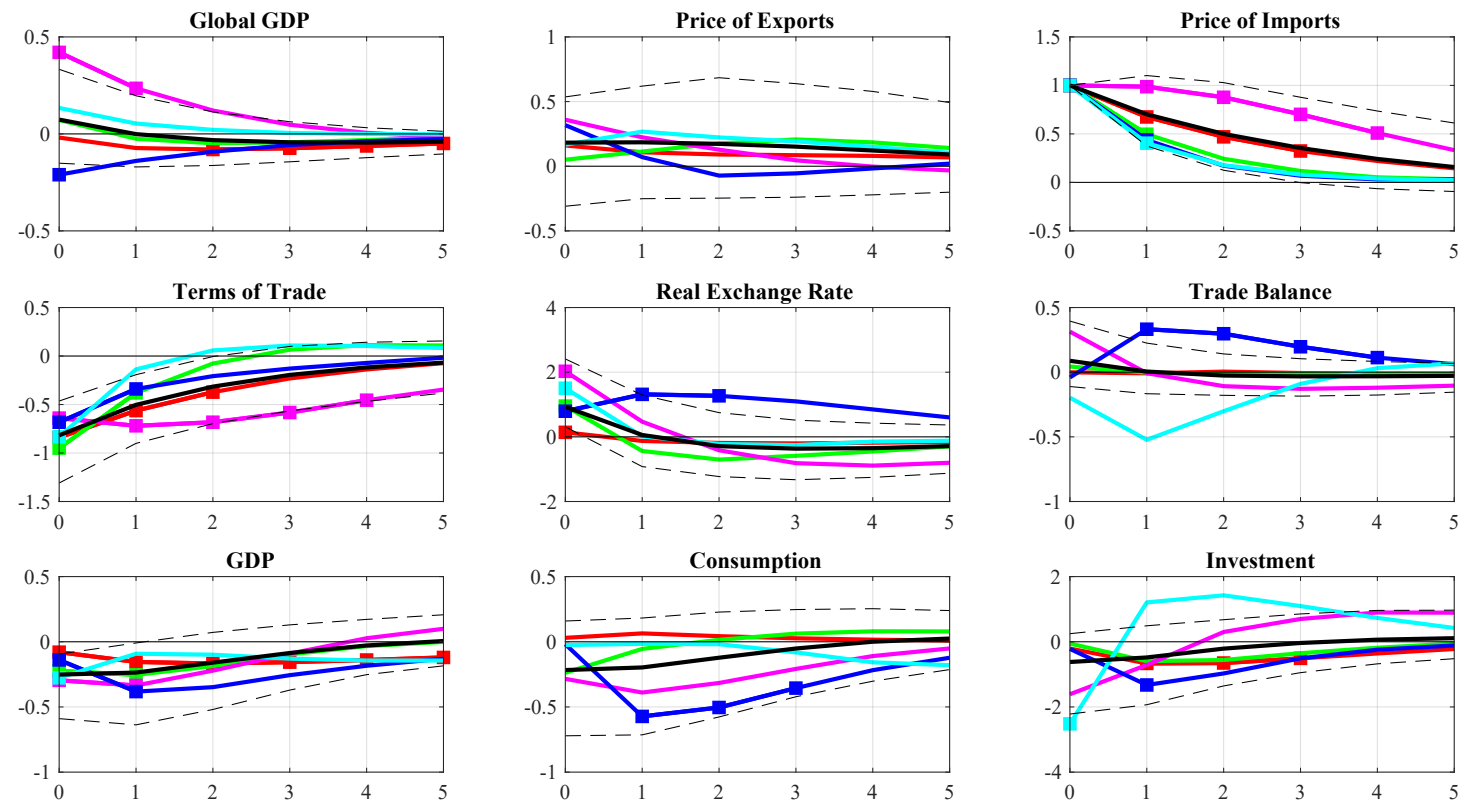

Notes: The figure shows the impulse responses to an import price shock for countries in each commodity group using a VAR with sign and narrative restrictions. Each color represents a different export group: agriculture (food and beverages) exporters are in green, energy exporters in magenta, manufacturing exporters in red, metal exporters in blue and agriculture raw material (plus fertilizers) exporters in turquoise. The lines denote the mean response weighted by each country's size proxied by their GDP (PPP). The squares denote that zero is not within the 68 percent confidence band. For comparison, the impulse responses for all countries are shown in black with the corresponding 16th and 84th percentile error bands. 
Figure D.4: Impulse Responses to a Global Economic Activity Shock by Export Group
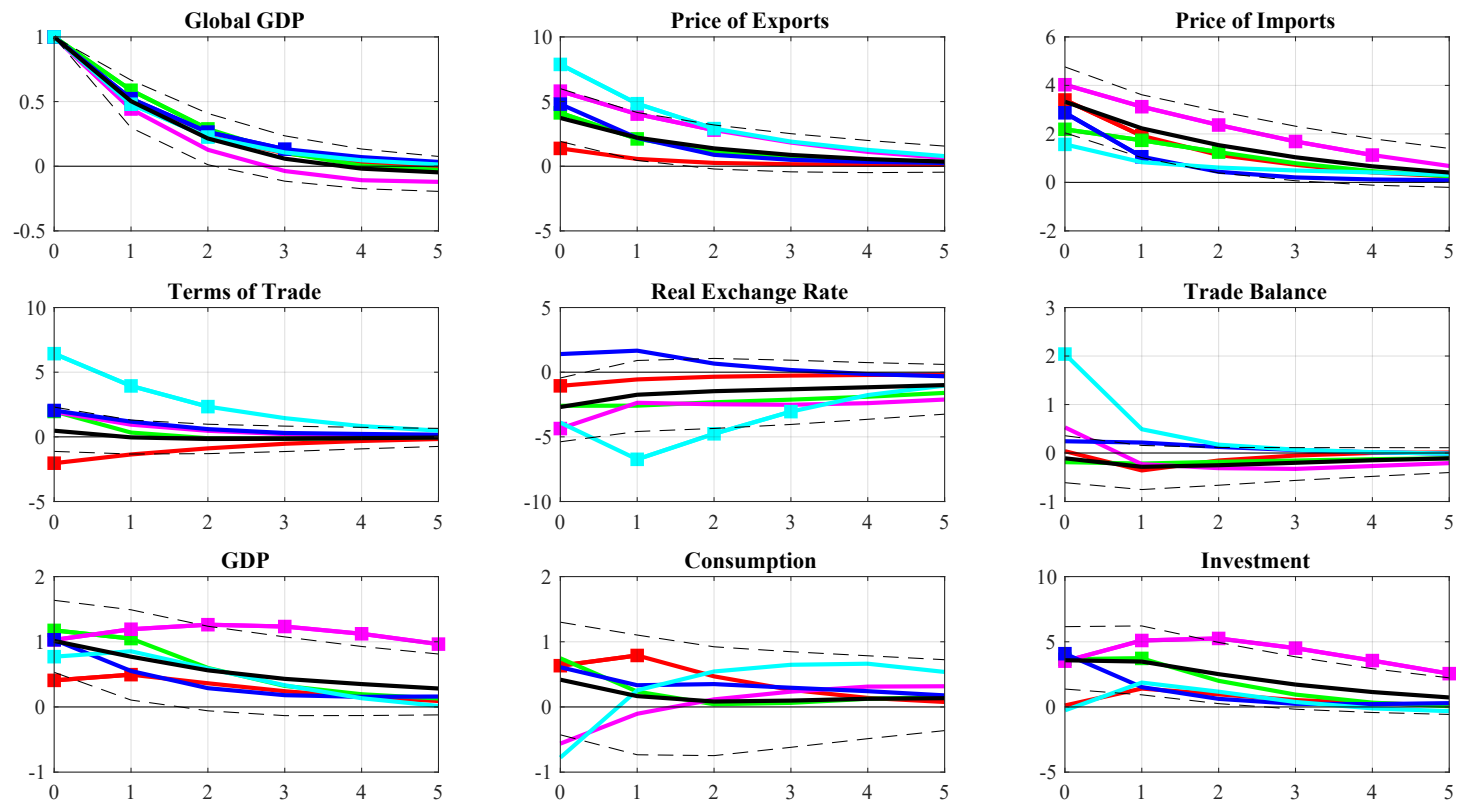

Notes: The figure shows the impulse responses to a global economic activity shock for countries in each commodity group using a VAR with sign and narrative restrictions. Each color represents a different export group: agriculture (food and beverages) exporters are in green, energy exporters in magenta, manufacturing exporters in red, metal exporters in blue and agriculture raw material (plus fertilizers) exporters in turquoise. The lines denote the mean response weighted by each country's size proxied by their GDP (PPP). The squares denote that zero is not within the 68 percent confidence band. For comparison, the impulse responses for all countries are shown in black with the corresponding 16th and 84th percentile error bands. 
Figure D.5: Impulse Responses to an Export Price Shock by Import Group
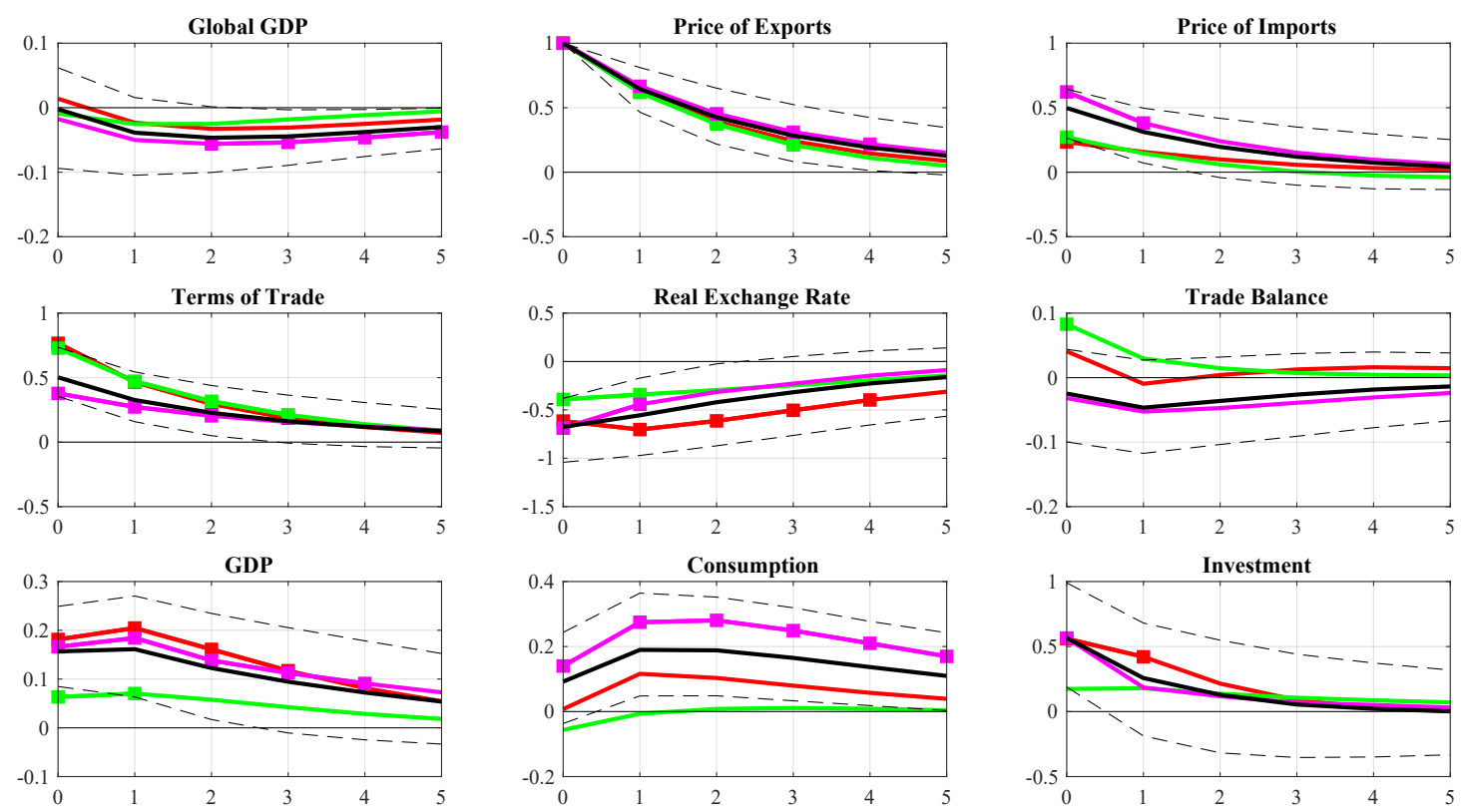

Notes: The figure shows the impulse responses to an export price shock for countries in each commodity group using a VAR with sign and narrative restrictions. Each color represents a different import group: agriculture (food and beverages) importers are in green, energy importers in magenta, and manufacturing importers in red. The lines denote the mean response weighted by each country's size proxied by their GDP (PPP). The squares denote that zero is not within the 68 percent confidence band. For comparison, the impulse responses for all countries are shown in black with the corresponding 16th and 84th percentile error bands.

Figure D.6: Impulse Responses to an Import Price Shock by Import Group
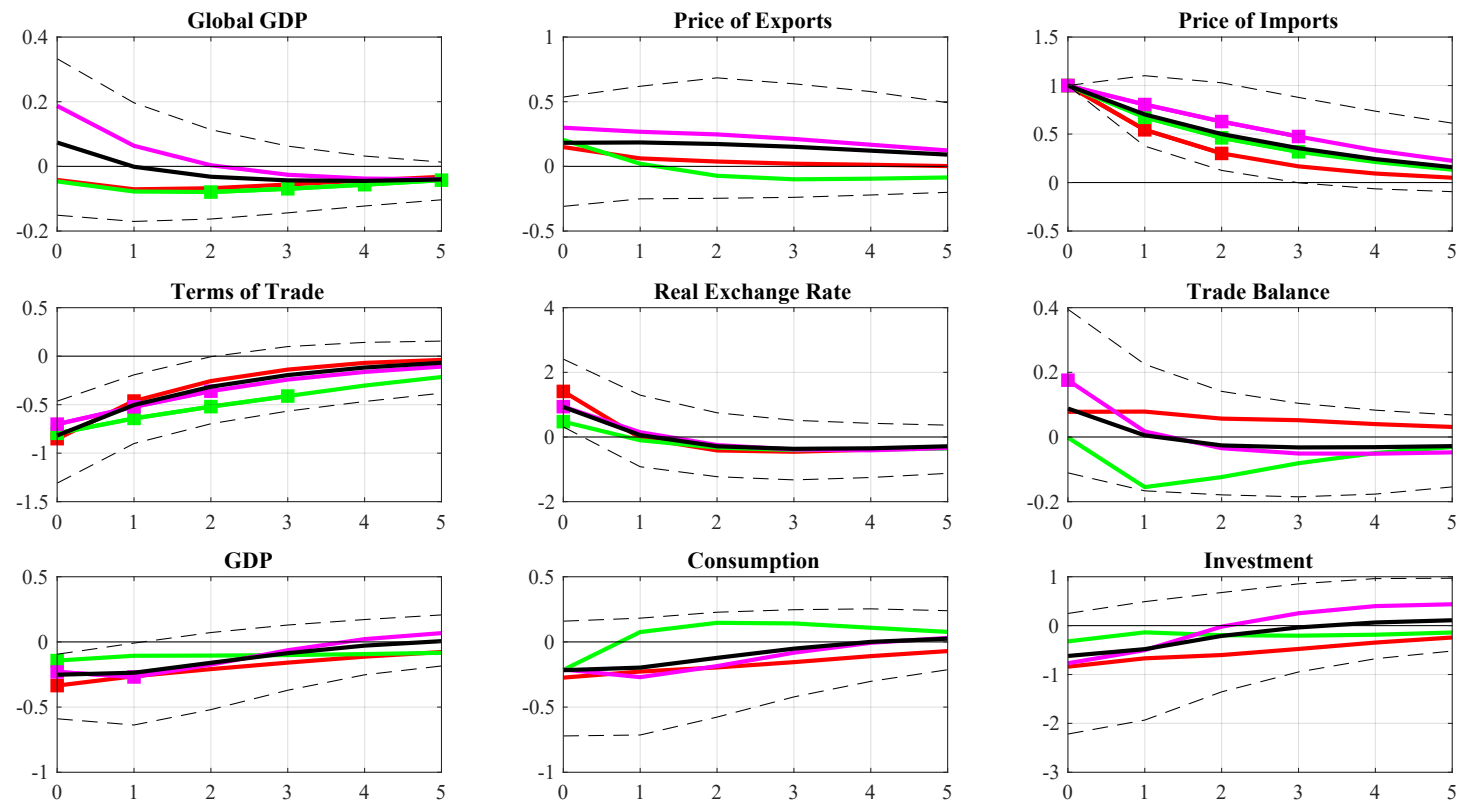

Notes: The figure shows the impulse responses to an import price shock for countries in each commodity group using a VAR with sign and narrative restrictions. Each color represents a different import group: agriculture (food and beverages) importers are in green, energy importers in magenta, and manufacturing importers in red. The lines denote the mean response weighted by each country's size proxied by their GDP (PPP). The squares denote that zero is not within the 68 percent confidence band. For comparison, the impulse responses for all countries are shown in black with the corresponding 16th and 84th percentile error bands. 
Figure D.7: Impulse Responses to a Global Economic Activity Shock by Import Group
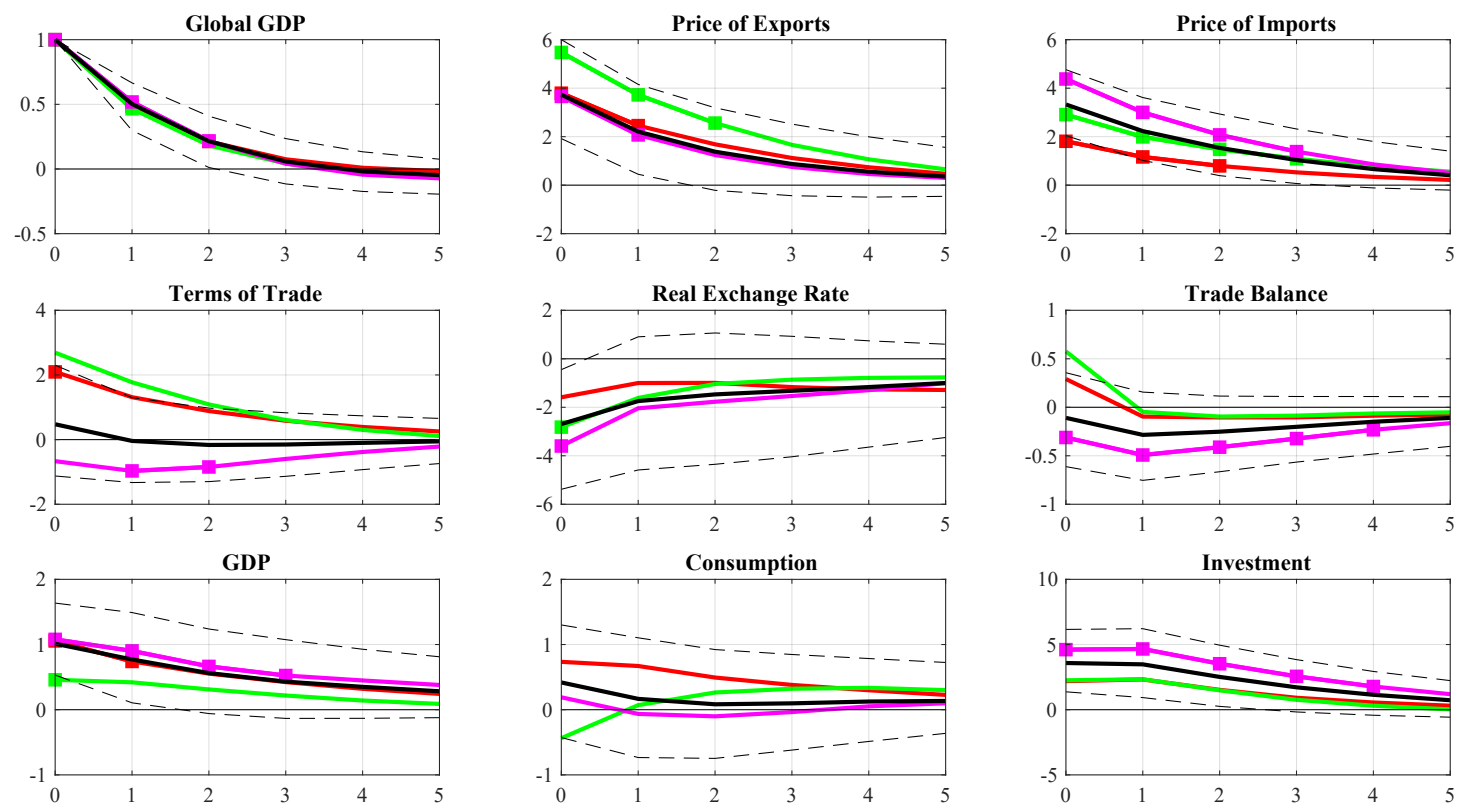

Notes: The figure shows the impulse responses to a global economic activity shock for countries in each commodity group using a VAR with sign and narrative restrictions. Each color represents a different import group: agriculture (food and beverages) importers are in green, energy importers in magenta, and manufacturing importers in red. The lines denote the mean response weighted by each country's size proxied by their GDP (PPP). The squares denote that zero is not within the 68 percent confidence band. For comparison, the impulse responses for all countries are shown in black with the corresponding 16th and 84th percentile error bands. 
Table D.2: FEVD International Prices: Commodity Groups

\begin{tabular}{|c|c|c|c|c|c|c|c|c|c|}
\hline & \multicolumn{3}{|c|}{ Exports Prices } & \multicolumn{3}{|c|}{ Imports Prices } & \multicolumn{3}{|c|}{ Terms of Trade } \\
\hline & $Y^{g}$ & $P^{x}$ & $P^{m}$ & $Y^{g}$ & $P^{x}$ & $P^{m}$ & $Y^{g}$ & $P^{x}$ & $P^{m}$ \\
\hline & \multicolumn{9}{|c|}{ Agriculture (Food and Beverages) Exporters } \\
\hline 0 & 32.07 & 64.26 & 3.67 & 26.76 & 39.26 & 33.98 & 22.73 & 46.46 & 30.82 \\
\hline \multirow[t]{2}{*}{10} & 31.03 & 60.83 & 8.14 & 31.98 & 41.64 & 26.39 & 23.44 & 48.98 & 27.58 \\
\hline & \multicolumn{9}{|c|}{ Energy Exporters } \\
\hline 0 & 24.88 & 73.17 & 1.95 & 44.88 & 29.88 & 25.24 & 18.18 & 78.21 & 3.61 \\
\hline \multirow[t]{2}{*}{10} & 27.59 & 68.06 & 4.35 & 42.71 & 35.29 & 22.00 & 25.06 & 64.76 & 10.18 \\
\hline & \multicolumn{9}{|c|}{ Manufacturing Exporters } \\
\hline 0 & 19.92 & 66.52 & 13.55 & 40.04 & 13.19 & 46.77 & 33.95 & 20.04 & 46.01 \\
\hline \multirow[t]{2}{*}{10} & 22.17 & 54.91 & 22.91 & 36.70 & 17.03 & 46.27 & 31.79 & 23.82 & 44.40 \\
\hline & \multicolumn{9}{|c|}{ Metals Exporters } \\
\hline 0 & 29.56 & 68.25 & 2.19 & 36.25 & 42.77 & 20.98 & 22.10 & 71.84 & 6.06 \\
\hline \multirow[t]{2}{*}{10} & 25.94 & 69.37 & 4.69 & 27.90 & 58.29 & 13.80 & 23.26 & 67.96 & 8.77 \\
\hline & \multicolumn{9}{|c|}{ Agriculture Raw Materials (plus Fertilizers) Exporters } \\
\hline 0 & 37.62 & 59.05 & 3.33 & 19.44 & 32.72 & 47.83 & 36.77 & 55.74 & 7.49 \\
\hline \multirow[t]{2}{*}{10} & 38.11 & 54.73 & 7.16 & 22.92 & 47.65 & 29.44 & 40.67 & 51.67 & 7.67 \\
\hline & \multicolumn{9}{|c|}{ Agricultural Importers } \\
\hline 0 & 28.27 & 68.15 & 3.58 & 35.97 & 20.75 & 43.28 & 22.91 & 59.83 & 17.26 \\
\hline \multirow[t]{2}{*}{10} & 29.88 & 59.03 & 11.09 & 34.98 & 28.72 & 36.30 & 25.70 & 54.01 & 20.29 \\
\hline & \multicolumn{9}{|c|}{ Energy Importers } \\
\hline 0 & 39.97 & 54.40 & 5.62 & 47.81 & 25.54 & 26.65 & 26.11 & 33.59 & 40.30 \\
\hline \multirow[t]{2}{*}{10} & 35.86 & 52.09 & 12.05 & 44.42 & 27.14 & 28.44 & 27.38 & 34.76 & 37.86 \\
\hline & \multicolumn{9}{|c|}{ Manufacturing Importers } \\
\hline 0 & 25.41 & 70.94 & 3.65 & 33.35 & 28.81 & 37.84 & 15.99 & 70.19 & 13.82 \\
\hline 10 & 28.30 & 65.25 & 6.45 & 33.70 & 36.39 & 29.91 & 20.91 & 64.75 & 14.34 \\
\hline
\end{tabular}


Table D.3: FEVD Business Cycle: Commodity Groups

\begin{tabular}{|c|c|c|c|c|c|c|c|c|c|c|c|c|}
\hline & \multicolumn{3}{|c|}{ Trade Balance } & \multicolumn{3}{|c|}{ Output } & \multicolumn{3}{|c|}{ Consumption } & \multicolumn{3}{|c|}{ Investment } \\
\hline & $Y^{g}$ & $P^{x}$ & $P^{m}$ & $Y^{g}$ & $P^{x}$ & $P^{m}$ & $Y^{g}$ & $P^{x}$ & $P^{m}$ & $Y^{g}$ & $P^{x}$ & $P^{m}$ \\
\hline & \multicolumn{12}{|c|}{ Agriculture (Food and Beverages) Exporters } \\
\hline 0 & 4.76 & 8.27 & 7.66 & 15.54 & 21.23 & 5.18 & 7.03 & 14.73 & 8.19 & 11.13 & 17.52 & 2.82 \\
\hline \multirow[t]{2}{*}{10} & 14.56 & 24.67 & 10.25 & 21.44 & 32.36 & 11.67 & 14.45 & 30.42 & 11.98 & 19.99 & 24.87 & 10.30 \\
\hline & \multicolumn{12}{|c|}{ Energy Exporters } \\
\hline 0 & 11.92 & 10.76 & 9.05 & 12.02 & 9.41 & 4.36 & 5.18 & 8.21 & 5.18 & 12.66 & 4.37 & 4.94 \\
\hline \multirow[t]{2}{*}{10} & 22.73 & 19.75 & 11.22 & 29.31 & 25.40 & 10.15 & 14.19 & 20.23 & 11.21 & 27.61 & 14.89 & 10.84 \\
\hline & \multicolumn{12}{|c|}{ Manufacturing Exporters } \\
\hline 0 & 11.91 & 4.91 & 5.13 & 8.70 & 8.29 & 5.15 & 13.67 & 6.50 & 5.15 & 3.87 & 9.60 & 6.04 \\
\hline \multirow[t]{2}{*}{10} & 23.76 & 12.87 & 20.46 & 16.60 & 14.24 & 24.66 & 23.79 & 15.95 & 20.21 & 15.96 & 18.87 & 21.96 \\
\hline & \multicolumn{12}{|c|}{ Metals Exporters } \\
\hline 0 & 7.46 & 8.40 & 2.33 & 20.95 & 8.99 & 2.45 & 11.25 & 5.48 & 3.26 & 11.81 & 10.79 & 2.62 \\
\hline \multirow[t]{2}{*}{10} & 11.56 & 17.01 & 16.76 & 19.40 & 20.13 & 15.41 & 15.09 & 15.79 & 14.62 & 16.04 & 23.61 & 12.57 \\
\hline & \multicolumn{12}{|c|}{ Agriculture Raw Materials (plus Fertilizers) Exporters } \\
\hline 0 & 12.02 & 5.99 & 3.74 & 4.24 & 12.61 & 3.60 & 7.48 & 4.73 & 3.77 & 4.96 & 8.17 & 15.73 \\
\hline \multirow[t]{2}{*}{10} & 17.40 & 16.17 & 7.35 & 14.17 & 19.27 & 13.35 & 13.75 & 26.39 & 11.57 & 12.36 & 20.80 & 17.22 \\
\hline & \multicolumn{12}{|c|}{ Agricultural Importers } \\
\hline 0 & 12.40 & 15.27 & 6.53 & 7.15 & 10.78 & 6.48 & 8.40 & 13.20 & 7.10 & 12.09 & 6.75 & 6.05 \\
\hline \multirow[t]{2}{*}{10} & 17.96 & 20.83 & 14.19 & 15.52 & 23.02 & 16.45 & 21.12 & 24.62 & 17.63 & 19.43 & 19.25 & 14.77 \\
\hline & \multicolumn{12}{|c|}{ Energy Importers } \\
\hline 0 & 9.28 & 6.06 & 8.19 & 23.60 & 13.43 & 7.87 & 6.00 & 8.35 & 6.21 & 19.99 & 10.01 & 3.56 \\
\hline \multirow[t]{2}{*}{10} & 24.43 & 17.26 & 13.35 & 30.67 & 25.68 & 14.71 & 13.37 & 29.52 & 13.61 & 32.33 & 15.73 & 10.99 \\
\hline & \multicolumn{12}{|c|}{ Manufacturing Importers } \\
\hline 0 & 10.53 & 7.38 & 6.79 & 14.42 & 14.18 & 8.68 & 10.54 & 5.27 & 9.29 & 11.22 & 12.08 & 7.63 \\
\hline 10 & 18.06 & 20.24 & 12.56 & 18.89 & 29.49 & 14.68 & 17.29 & 17.47 & 15.06 & 20.07 & 19.91 & 14.66 \\
\hline
\end{tabular}




\section{References}

Cavallo, A., And M. Bertolotti (2016). "Filling the Gap in Argentina's Inflation Data Rates," mimeo.

DALY, M. (2001). "Economic Impact of Rising Natural Gas Prices," FRBSF Economic Letter, Federal Reserve Bank of San Francisco.

De Winne, J., And G. Peersman (2016). "Macroeconomic Effects of Disruptions in Global Food Commodity Markets: Evidence for the United States," Brookings Papers on Economic Activity, The Brookings Institution, vol. 47(2), 183-286.

Food and Agriculture Organization of the United Nations (1984). "The State of Food and Agriculture," FAO Rome.

Food and Agriculture Organization of the United Nations (1989). "Commodity Review and Outlook 1988-89," FAO Rome.

Food and Agriculture Organization of the United Nations (1994). "Commodity Review and Outlook 1993-94," FAO Rome.

Food and Agriculture Organization of the United Nations (1996). Food Outlook Global Information and Early Warning System, Commodities and Trade Division, FAO Rome.

Food and Agriculture Organization of the United Nations (2010). "Crop Prospects and Food Situation," Food Outlook Global Information and Early Warning System, Commodities and Trade Division, FAO Rome.

Hamilton, J. (2013). "Historical Oil Shocks." In R.E. Parker and R.M. Whaples (Eds.), Handbook of Major Events in Economy History pp. 239-265, New York: Routledge Taylor and Francis Group.

International Coffee Organization (2014). "World Coffee Trade (1963-2013): A Review of the Markets, Challenges and Opportunities Facing the Sector," London, United Kingdom.

International Monetary Fund (1987). "Primary Commodities Market Developments and Outlook," World Economic and Financial Surveys, Washington, D.C..

International Trade Commission (1995). "U.S. Trade Shifts in Selected Industries: Merchandise," Annual Report, Washington D.C..

Janzen, P.J., A. Smith, and C.A. Carter. (2018). "Commodity Price Comovement and Financial Speculation: The Case of Cotton," American Journal of Agricultural Economics 100(1), 264-285.

Karrenbrock, J, D. (1989). "The 1988 Drought: Its Impact on District Agriculture," Federal Reserve Bank of St. Louis Review 71(3).

MacDonald, D. and L. Meyer (2018). "Long Run Trends and Fluctuations in Cotton Prices," MPRA Working Paper 84484.

Schmitt-Grohé And Uribe (2018). "How Important are Terms-of-Trade Shocks?," International Economic Review 59(1), 1-27. 
Sohngen, B.L. And R.W. Haynes (1994). "The 'Great' Price Spike of '93: An Analysis of Lumber and Stumpage Prices in the Pacific Northwest," United States Department of Agriculture, Forest Service Research Paper PNW-RP-476.

U.S. Department of the Interior (1999). "Metal Prices in the United States Through 1998," U.S. Geological Survey, Washington, D.C..

World Bank (1989). "Price Prospects for Major Commodities, 1988-2000," Washington, D.C.. 